\title{
Autonomy or Community? An Evaluation of Two Models of Parental Obligation
}

\author{
Marsha Garrison $\dagger$
}

The article examines this question: How much do parents owe their children? It describes the historical development of the child support obligation and current support "guidelines," mandated by Congress with the hope of raising support levels. It utilizes several distributive justice theories to evaluate the guidelines, concluding that they fail under any approach. The article explains that all of the surveyed distributive justice theories lead to one of two support models. The "Community Model" bases the support obligation on family membership and mandates income sharing as a basic approach. The "Autonomy Model" bases the support obligation on both the societal burden produced by nonsupport and the nonsupporting parent's contractual obligations to the custodial parent; it mandates public assistance (or poverty) prevention and contract enforcement as basic goals. The Article describes the results that the Community and Autonomy models would achieve and evaluates available evidence bearing on the choice of a model, including survey data on public attitudes toward the support obligation, the extent to which each model is consistent with the assumptions implicit in related areas of law, and the ability of each model to meet the policy concerns that motivated the child support initiatives in the first place. It concludes that the Community Model is the better choice.

How much do parents owe their children? Does parental obligation derive primarily from the burdens that a child may impose on society and on the other parent, or from parent's and child's joint membership in a sharing community?

Copyright 191998 California Law Review, Inc.

$\dagger$ Professor of Law, Brooklyn Law School. I owe thanks to Claire Finkelstein, Sally Goldfarb, Mitt Regan, and Tony Sebok for their comments on an earlier draft of the manuscript and to Brooklyn Law School's Faculty Research Fund for its support. 
Any society's answers to these questions will tell us a good deal about its basic values and conception of family life. Our own society's answers will also play a crucial role in determining the current wellbeing and future prospects of half or inore of our children; given current rates of divorce and nonmarital childbearing, at least $50 \%$ of American children, for some portion of their childhood years, are expected to be eligible for child support from a nonresident parent. ${ }^{1}$

The results achieved by child support laws-and the conception of parental obligation that underlies them-are important not only to children and their parents, but to the public as well. Family dissolution and nonsupport are currently major causes of children's poverty and welfare dependence. ${ }^{2}$ Children in single-parent households are also more likely to experience poor health, behavioral problems, delinquency, and low educational attainment than are their peers in intact families; as adults they have higher rates of poverty, early childbearing, and divorce. ${ }^{3}$ While these outcomes do not result solely from reduced economic status, this factor appears to be the most important of the identifiable causes. ${ }^{4}$

1. Researchers currently estimate that half to three-quarters of children born in the late $1970 \mathrm{~s}$ or 1980s will spend some portion of their childhood years in a single-parent household. For a critical review of the estimates, see Donald J. Hernandez, AMERICA's ChIldREN: Resources From FAMILY, GOVERNMENT, AND THE ECONOMY 69-71 (1993). As many as 90\% of African-American children will spend time in a single-parent family. See, e.g., ROBERT HAveMan \& Barbara WOLFe, SucceEding Generations: ON THE EFFECTS OF INVESTMENTS IN CHILdREN 19 n.2 (1994).

2. See, e.g., Mary Jo Bane, Household Composition and Poverty, in Fighting Poverty: What Works and What Doesn't 231 (Sheldon H. Danziger \& Daniel H. Weinberg eds،, 1986) (concluding from analysis of 1970 s census data that "perhaps about $15 \%$ of all poverty could be alleviated by more attention to the allocation of resources after household splits"); Greg J. Duncan \& Willard L. Rodgers, Longitudinal Aspects of Childhood Poverty, 50 J. MARRIAGE. \& FAM. 1007, 1017 tbl.5 (1988) (concluding from analysis of $1968-82$ census data that $14.9 \%$ of children's transitions into poverty resulted from loss of a parent from the home). In I993, 45\% of AFDC entrants became eligible for benefits as a result of marital separation or divorce. See U.S. CoNGREss, House Op Representatives, 1994 Green Book: Overview Of Entmlements Programs 451 tbl.10-50. See also Peter J. Leahy et al., Time on Welfare: Why Do People Enter and Leave the System?, 54 AM. J. EcoN. \& Soc. 33 (1995) (reporting change in family structure as the primary reason women enter welfare system).

3. See Hernandez, supra note 1, at 58-64; S. Wayne Duncan, Economic Impact of Divorce on Children's Development: Current Findings and Policy Implications, 23 J. Clinical ChiLd Psychol. 444, 451-53 (1994); Sara McLanahan, Intergenerational Consequences of Divorce: The United States Perspective, in Economic Consequences of Divorce: The INTERnational Perspective 285 (Lenore J. Weitzman \& Mavis Maclean eds., 1992) [hereinafter McLanahan, Intergenerational Consequences]; Sara S. McLanahan et al., The Role of Mother-Only Families in Reproducing Poverty, in Children In Poverty: Child Development and Public Policy 51 (Aletha C. Huston ed., 1991).

4. See Sara Mclanahan \& Gary Sandefur, Growing Up With a Single Parent: What Helps, What HuRTs 3, $79-94$ (1994) ("Low income-and the sudden drop in income that often is associated with divorce is the single most important factor in children's lower achievement in single-parent homes, accounting for about half of the disadvantage."); McLanahan, Intergenerational Consequences, supra note 3, at 292-93, 298 (suinmarizing studies and concluding that "income 
Given the serious and costly consequences associated with low support payments, it is not surprising that the interest of law makers and the public has expanded along with the number of support-eligible children. Beginning in 1979, the Census Bureau began to collect biennial child support data. Its first national survey revealed what many had already suspected: American child support laws were not producing results that protected either children or the public. Only three-fifths of women eligible to receive child support had obtained support orders. ${ }^{5}$ Only about half of those awarded support received full payment. ${ }^{6}$ The average value of child support paid $^{7}$ was less than half of what economists estimate as typical child-rearing costs ${ }^{8}$ and only $12 \%$ of average male earnings for that year. ${ }^{9}$ Research at the state level also documented considerable variation in award values, even among families of similar size and socioeconomic characteristics. ${ }^{10}$

explains more than half of the ... [child outcome] variation across family types"). See also Duncan, supra note 3 (reviewing research).

5. See U.S. Dep't of Commerce, Bureau of the Census, Child Support and Almony: 1978, at 3 tbl.A (Current Population Reports, Series P-23, No. 106, 1980) [hereinafter 1978 CHILD SupPORT REPORT] (reporting that $59.1 \%$ of women survey respondents who had one or more children under 21 years of age had been awarded support from an absent father in 1978).

6. See id. (reporting that, in 1978, $48.9 \%$ of women survey respondents who had been awarded child support received full payment).

7. See id. at 3 tbl.B (reporting average value in 1978 of child support received as \$1799).

8. See Andrea H. Beller \& John W. Graham, Small Change: The Economics of ChIld Support 38-39 (1993) (estimates of average annual parental expenditure per child range from $\$ 3245$ to $\$ 4925$ in 1985 dollars, or two to three times the average amount of child support due).

9. See id. at 35 tbl.2.7. Child support obligors report paying even smaller proportions of their incomes in child support. See Cynthia Needles Fletcher, A Comparison of Incomes and Expenditures of Male-Headed Households Paying Child Support and Female-Headed Households Receiving Child Support, 38 FAM. Relations 412, 414 (1989) (reporting that 1985 male PSID respondents who had paid child support paid, on average, $9.5 \%$ of their current mcomes).

10. See, e.g., Joseph I Lieberman, Child Support IN AMerica: Practical Advice por Negotiating-And Collecting-A Fair Setrlement 12 (1986) (reporting that in random Connecticut sample of fathers with one child who earned between $\$ 145$ and $\$ 155$ per week, support ordered ranged from $\$ 10$ to $\$ 60$ per week); Ann Nichols-Casebolt et al., Reforming Wisconsin's Child Support System, in State Policy Choices: The Wisconsin Experience 172, 176-77 tbl.9.2 (Sheldon Danziger \& John F. Witte eds., 1988) (reporting that sample Wisconsin child support awards ranged from zero to more than $100 \%$ of noncustodial father's income); Kenneth $\mathrm{R}$. White \& $\mathrm{R}$. Thomas Stone, Jr., A Study of Alimony and Child Support Rulings with Some Recommendations, 10 FAM. LQ. 75, 83-84 (1976) (reporting that, in Orange County, Florida, alimony and child support awards to families in similar circumstances varied widely based on differing judicial philosophies); Lucy Marsh Yee, What Really Happens in Child Support Cases: An Empirical Study of Establishment and Enforcement of Child Support Orders in the Denver District Court, 57 DeNv. L.J. 21 (1979) (concluding that judicially ordered child support in Denver varied widely). But see Marsha Garrison, How Do Judges Decide Divorce Cases? An Empirical Analysis of Discretionary Decision Making, 74 N.C. L. REv. 401, $491-92$ \& 492 n.315 (1996) (reporting that in New York sample of stipulated child support awards, obligor's income, percentage of family income earned by custodial parent, nuunber of minor children, custodial parent's net property award, and case duration accounted for $44 \%$ of case variation; among judicial awards obligor's income, decision year, number of minor children, and the custody decision accounted for 54\% of case variation); Marygold S. Melli et al., The Process of Negotiation: An Exploratory Investigation in the Context of No-Fault Divorce, 40 RuTGERS L. REv. 
Over the past twenty years, both the federal and state governments have enacted laws designed to improve this dismal record. ${ }^{11}$ While the reform effort has altered many aspects of child support practice, the most sweeping shift has been in the determination of support award values. Traditional support laws urged consideration of the child's needs, prior standard of living, and parental resources, but left to judicial discretion the task of translating these factors into a dollars and cents payment schedule. ${ }^{12}$ Today, based on directives from Congress, ${ }^{13}$ each state has adopted numerical guidelines governing the value of child support. $^{14}$ While these guidelines need only establish a rebuttable presumption as to the child support amount, deviation must be justified in a written decision. ${ }^{15}$

While Congress adopted the numerical guidelines requirement with the aim of significantly increasing award levels and decreasing award variability, ${ }^{16}$ available evidence suggests that these goals have not been met. Awards calculated under existing guidelines do not appear to differ dramatically from those produced under earlier discretionary standards. ${ }^{17}$ Many guidelines fail to ensure that children are protected from poverty, even when parental income is adequate to meet that goal. ${ }^{18}$ Moreover, they often improve the living standard of the child support obligor, while causing that of his child to plummet. ${ }^{19}$ Today's

1133, 1164 (1988) (reporting that in sample of stipulated and judicial child support awards, numbcr of children, income of supporting parent, and couple's estimated net worth accounted for almost 50\% of variation in child support values).

11. The trend is not unique to the United States. See, e.g., J. Thomas Oldham, Lessons from the New English and Australian Child Support Systems, 29 VAND. J. TRANSNAT'L L. 691 (1996).

12. For a description of traditional child support law, see HOMER H. ClARK, JR., THE LAW OF Domestic Relations in the United States $488-498$ (1st ed. 1968) [hereinafter Clatk, First EDITION].

13. See, e.g., Family Support Act of 1988, Pub. L. No. 100-485, 102 Stat. 2343 (codified as amended in scattered sections of 42 U.S.C.).

14. For state-by-state descriptions of the guidelines, see Diane Dodson \& JOAN ENTMACHER, Women's Legal Defense Fund, Report Card on State Child Support Guidelines (1994); Janice T. Munsterman et al., National Center for State Courts, A Summary of Child SUPPORT GUIDELINES (1990).

15. See Family Support Act of 1988, Pub. L. No. 100-485, § 103(a), 102 Stat. 2343, 2346 (codified as amended at 42 U.S.C. $\$ 667(b)(2)(1991)$ ).

16. See Irwin Garfinkel \& Marygold S. Melh, The Use of Normative Standards in Family Law Decisions: Developing Mathematical Standards for Child Support, 24 FAM. LQ. 157, 160-62 (1990); Robert G. Williams, An Overview of Child Support Guidelines in the United States, in CHILD SUPPORT Guidelines: The Next Generation 15 (Margaret C. Haynes ed., 1994) [hereinafter Next Generation].

17. See sources cited infra notes 111-116.

18. See sources cited infra notes 129-130.

19. See sources cited infra note 131 . 
child support laws thus prefer the interests of the nonresident parent to those of the child, the custodial parent, and the public. ${ }^{20}$

Are these results fair? Are they compatible with contemporary views on parental obligation, family relationships, and distributive justice? Current guidelines offer no answers to these questions, as they lack an articulated theory of the support obligation to ground their design and justify their results. ${ }^{21}$ Most were derived from economic models of household expenditure in intact families, not from a decision about what income allocation would be fair in a divided family. The literature on child support today thus focuses almost exclusively on details ${ }^{22}$-child care costs, extraordinary medical expenses, joint custody, extended visitation-without regard to basic goals or principles. ${ }^{23}$

Nor are the right goals and principles immediately apparent. Social theorists have seldom addressed either issues of justice within the family or the extent of a parent's obligation to ensure that his children do not burden the community. Although the classical social theorists analyzed the relationship between family and society extensively, ${ }^{24}$ they tended to view the parent-child relationship as one governed by altruism rather than the constraints of formal justice. ${ }^{25}$ Although this assumption is clearly inadequate when applied to parents and children who live

20. For a similar view, see Daniela Del Boca \& Christopher J. Flinn, Rationalizing Child-Support Decisions, 85 AM. ECON. REv. 1241 (1995) (concluding, based on economic analysis, that implicit weight attached to combined post-divorce welfare of custodial mother and child was significantly less than that attached to father's welfare in most sample cases).

21. For similar views, see Laurie J. Bassi \& Burt S. Barnow, Expenditures on Children and Child Support Guidelines, 12 J. POL'Y ANALYSIS \& MGMT. 478, 495 (1993) ("To determine if a given guideline is fair, one must first ascertain the standard of faimess that is to be applied. Thus, we recommend that states explicitly consider the fairness criteria they would like to attain."); David Betson et al., Trade-Offs Implicit in Child-Support Guidelines, 11 J. Pol'y ANALYS1S \& MGMT. 1, 19 (1992) ("[C]hildren stand to gain if policy makers would address explicitly the trade-offs implicit in child-support guidelines."); Andrea Giampetro, Mathematical Approaches to Calculating Child Support Payments: Stated Objectives, Practical Results, and Hidden Policies, 20 FAM. L.Q. 373, 391 (1986) (arguing that mathematical child support formulae are "merely tools...to rationalize ... hidden views on child support pohicy").

22. For examples of the literature on child support guidelines, see IRWIN GarfinkEL, Assuring Child Support: AN Extension of Social Security 85-101 (1992); Women's Legal Defense Fund, Essentials of Child Support Guidelines Development: Economic Issues AND Policy Considerations: Proceedings of the IWomen's Legal Defense Fund's National Conference on the Development of Child Support Guidelines (1987) [hereinafter EsSENTIALS OF CHILD SupPoRT]; Garfinkel \& Melli, supra note 16; Sally F. Goldfarb, Child Support Guidelines: A Model for Fair Allocation of Child Care, Medical, and Educational Expenses, 21 FAM. L.Q. 325, 330-49 (1987); Williams, supra note 16.

23. For a noteworthy exception, see Betson, supra note 21.

24. For a useful summary of western philosophical writing on the family, see JEFFREY Blustein, Parents and Children: The Ethics of the Family 19-98 (1982). See also Jacob J. Ross, The VIRTUes OF The FAMILY 124-35 (1994).

25. See infra note 160 and sources cited therein. 
apart, ${ }^{26}$ critics have only recently begun to challenge $i t^{27}$ and even the critics have failed to develop normative standards for measuring parental obligation. ${ }^{28}$

The lack of an established ethical tradition relating to child support may help to explain policy makers' failure to articulate a theoretical basis for current support guidelines, but does not excuse it. In a society in which law will prescribe the economic relationships of at least half of the children and their parents, ${ }^{29}$ we cannot afford to disregard issues of justice between family members. The family as a set of affective and altruistic relationships may lie beyond the realm of justice, but family law most certainly does not.

In this Article, I aim to develop child support standards that are grounded in primciples of distributive justice and contemporary views of parental obligation. This is a large task and I do not claim to have resolved all of the important questions; my intention is to spur more thinking on this important topic, not to have the last word. My analysis of child support policy will be both political and interpretive..$^{30}$ By political, I mean that I will assume current child support law and institutions are alterable, rather than predetermined by culture, history, or economic organization. ${ }^{31}$ By interpretive, I mean that I will analyze child support policy by examining past and current support law's

26. Parents separated from their children are not only much less likely than custodial parents to support their minor children, see supra notes 5, 9-10, but also are less likely to share assets and income with their adult children. See Frank F. Furstenberg, Jr. et al., The Effect of Divorce on Intergenerational Transfers: New Evidence, 32 DEMOGRAPHY 319 (1995) (finding that, following late divorces, fathers and mothers had similar rates of asset transfer to their adult children while divorce during childhood years was associated with a sharp decrease in transfers by fathers and increase in transfers by custodial mothers; fathers who paid child support were not morc likely to make intergenerational transfers); Nadine F. Marks, Midlife Marital Status Differences in Social Support Relationships with Adult Children and Psychological Well-Being, $16 \mathrm{~J}$. FAM. Issues 5 (1995) (finding that remarried and single parents generally professed less belief in parental financial obligation and were less likely to give support to their adult children than first marriage parents).

27. See, e.g., SusAn M. OKIN, JuSTICE, GENDER, AND THE FAMILY 9 (1989) (arguing that contemporary theories of justice "rcfuse even to discuss the family and its gender structure, much less to recognize the family as a pohtical institution of primary importance."); Stephen G. Post, Justice, Redistribution, and the Family, J. Soc. PHIL. 91 (Fall-Winter 1990) (describing tendency of modern distributive justice theories to iguore the family); Peter Vallentyne \& Morry Lipson, Equal Opportunity and the Family, 3 PuB. AFF. Q. 27 (October, 1989) (arguing incompatibility of parental autonomy and liberal principle of equal oportunity).

28. See OKIN, supra note 27; Onora O'Neill, Children's Rights and Children's Lives, 98 ETHICs 445 (1988); Ferdinand Schoeman, Rights of Children, Rights of Parents, and the Moral Basis of the Family, 91 ETHics 6 (1980); Christina H. Sommers, Philosophers Against the Family, in Person to PERSON 82 (George Graham \& Hugh Lafollette eds., 1989).

29. See HERNANDEZ, supra note 1 , at 69-71.

30. I am indebted to Edward J. McCaffery for this succinct methodological description. See Edward J. McCaffery, The Uneasy Case for Wealth Transfer Taxation, 104 Y ALE L.J. 283, 286-87 (1994).

31. For a description of political analysis, see John Rawls, Political Liberalism $11-15$ (1993) [hereinafter Rawls, Political Liberalism]. 
implicit assumptions about family income entitlements and comparing them with contemporary accounts of distributive justice, economic entitlements based on marriage, and public attitudes toward parental obligation and fairness; I will not employ a "top-down" approach that assumes acceptance of one or another basic allocational principle. ${ }^{32}$

An interpretive approach to child support policy is preferable to a top-down approach for a variety of reasons. First, there are several basic principles one might utilize in designing a child support rule, but no obvious noninterpretive reason to choose one over another. ${ }^{33}$ Second, there is widespread agreement among family law scholars that the expression of contemporary values and beliefs is one of family law's most important functions. ${ }^{34}$ Third, researchers have found that those subject to a law evaluate it normatively, and are more likely to obey those laws that they find fair. ${ }^{35}$ These various considerations suggest that a just child support law will conform to our considered judgments about fairness among family members and the scope of parental obligation. They also suggest that a child support law failing to conform to those judgments will not garner public respect and allegiance.

Part I of the Article describes the historical development of the child support obligation, its relationship to public assistance law, and its links with spousal support and family property rules. Part II describes the child support guidelines that have recently been enacted, the assumptions upon which they are based, and the results that they achieve. Part III describes several different contemporary theories of

32. For a description of the interpretive approach, see RONALD DWORKIN, LAw's EMPIRE 4586 (1986); cf. Jules L. Coleman, Risks AND Wrongs 8-9, 441 (1992) (discussing the top-down approach). See also McCaffery, supra note 30, at 286 (defining interpretive approach as one "that looks for norms in society's actual practices and beliefs" and noting important role of interpretive theories in common law fields such as torts and contracts and in constitutional law). The interpretive approach is consistent with the ideal of public reason as the means by which a society makes decisions. For accounts and defenses of the public reason ideal, see RawLs, Political LIBERALISM, supra note 31, at 212-54; Joshua Cohen, Moral Pluralism and Political Consensus, in THE IDEA of Democracy 270 (David Copp et al. eds., 1993); John Rawls, The Idea of Public Reason Revisited, 64 U. Chi. L. Rev. 765 (1997) [hereinafter Rawls, Public Reason].

33. See DwORKIN, supra note 32, at 408 ("None [of the available philosophical theories] fits well enough to dominate present law overall; all fit well enough to claim a base within it.").

34. For analyses of the expressive function of family law, see MILTON C. REGAN, JR., FAMILY LAW AND The Pursuit of INTIMAcy 176-84 (1993); Carl E. Schneider, The Channelling Function in Family Law, 20 Horstra L. REv. 495 (1992); Carol Weisbrod, On the Expressive Functions of Family Law, 22 U.C. DAvis L. Rev, 991 (1989).

35. See, e.g., Tom R. Tyler, Why People Obey the Law 178 (1990) (concluding, based on extensive empirical research, that "people ... evaluate laws and the decisions of legal authorities in normative terms, obeying the law if it is legitimate and moral and accepting decisions if they are fairly arrived at."); Tom Tyler \& Robyn M. Dawes, Faimess in Groups: Comparing the Self-Interest and Social Identity Perspectives, in Psychological Perspectives on Justice 87, 89-90 (Barbara A. Mellers \& Jonathan Barron eds., 1993) (summarizing research). 
distributive justice and the child support principles that they would generate, concluding that all theories lead to one of two different guideline models. The "Community Model" bases the support obligation on family membership and mandates income sharing as a basic approach. The "Autonony Model" bases the support obligation on both the societal burden produced by nonsupport and the nonsupporting parent's contractual obligations to the custodial parent; it mandates public assistance (or poverty) prevention and contract enforceinent as basic goals. Part III also compares current child support guidelines with both the Community and Autonomy Models, concluding that they fail under either approach. Part IV describes the results that the Community and Autonomy Models would achieve and evaluates available evidence bearing on the choice of a model, including survey data on public attitudes toward the support obligation, the extent to which each inodel is consistent with the assumptions implicit in related areas of law, and the ability of each model to ineet the policy concerns that motivated the child support initiatives in the first place. Part IV concludes that the Community Model is the better choice.

I

\section{Child Support in Retrospect: The Development of the Child SUPPORT OBLIGATION}

A legal child support obligation might be derived from any of three parental duties-to the child, to the other parent, or to the community. The first child support laws relied exclusively on the parent's community obligations. But, from time to time, support laws have relied on each form of parental obligation. Child support has consistently been linked with contemporary laws governing family relationships and public assistance entitlements. Economic and cultural norms have also played an important role in shaping the support obligation.

\section{A. Parental Obligation to the Community: The Poor Law Origins of Child Support Law}

The first statement of a legal child support obligation within Anglo-American sources is contained in the Elizabethan Poor Laws. ${ }^{36}$ The Poor Laws resulted from economic conditions that created a large class of landless, often destitute laborers. ${ }^{37}$ Agrarian parents, who shared

36. See 43 Eliz., ch. $2, \S \S$ I, III and V (I601) (Eng.).

37. For detailed descriptions of the economic and social dislocations that gave rise to the Poor Laws, see, Joyce O. APpleby, Economic Thought and IDEology in Seventeenth-Century ENGland 129-57 (1978); W.K. Jordan, Philanthropy in England, 1480-1660: A Study op 
the work of economic production with their children in a fixed location, could be counted on to share their resources. But the parents of this new laborer class, who were often forced to seek work at a distance and derived no economic benefit from their children, could not be counted on to provide support.

The Poor Laws transformed moral duties-of family members toward each other and of the community toward its members-into legal obligations. ${ }^{38}$ They instituted a comprehensive public welfare program, funded through taxation, that provided assistance to needy members of the community whenever family support was unavailable. ${ }^{39}$ They also established a legal support obligation that required parents and other specified relatives to reimburse the community for public aid. ${ }^{40}$ The Laws restricted direct monetary assistance to those incapable of self-help; rather than receiving support im their parents' home, children thus were indentured as apprentices. ${ }^{41}$

\section{B. Obligations within the Family: From Moral Duty to Equitable Remedy}

In contrast to the Poor Laws' clear statement of community entitlement to enforce parental responsibility, the Common Law accorded the child no legally enforceable support right. Like his contemporaries, Blackstone held that the "insuperable degree of affection" between parent and child was a sufficient guarantor of parental support to obviate the need for legal sanctions. ${ }^{42}$ In keeping

the Changing Pattern of English Social Aspirations 58-86 (1959); Sidney Webb \& Beatrice Webb, English Poor law History, Part I: The Old Poor Law (1927).

38. See Brian Tierney, Medieval Poor law: A Sketch of Canonical Theory and its ApPLICATION IN ENGLAND 44-109 (1959) (describing charitable obligations of individuals and religious institutions under medieval ecclesistical law).

39. The program drew together previous ad hoc attempts to cope with the social and economic problems created by this new laborer class. See JoRdan, supra note 37; WeBв \& WeBB, supra note 37; Jacobus tenBroek, California's Dual System of Family Law: Its Origins, Development, and Present Status, Part l, 16 StAN. L. Rev. 257, 257-87 (1964).

40. Children were eligible for public aid when abandoned, orphaned, or when their parents were not "able to keep and maintain [them]." 43 Eliz. ch. 2, § I (1601) (Eng.). The manner and rate of parental reimbursement were determined by county Justices of the Peace; default resulted in a standard penalty of twenty shillings per month. See id. at ch. $2, \S \S$ V, VI, VII. See also tenBroek, supra note 39, at 282-85.

41. See 43 Eliz., ch. 2, $\S$ I, V (1601) (Eng.); Judith Areen, Intervention Between Parent and Child: A Reappraisal of the State's Role in Child Neglect and Abuse Cases, 63 Geo. L.J. 887, 895-96 (1975); Marsha Garrison, Why Terminate Parental Rights?, 35 StaN. L. Rev. 423, 434-35 (1983); tenBroek, supra note 39, at 278-82. Contemporary writers typically urged apprenticeship at the age of five or six. See, e.g., APPLEBY, supra note 37, at 141 (quoting various seventeenth century pamphlets).

42. I William Blackstone, Commentaries on the laws of England *447 ("By begetting them, therefore, they have entered into a voluntary obligation, to endeavor, as far as in them lies, that the life which they have bestowed shall be supported and preserved."). One group of commentators has argued that the Common Law courts' reluctance to create a legally enforceable 
with this view, eighteenth-century English and American courts provided children with no assistance in obtaining parental support beyond the Poor Laws. ${ }^{43}$

The Common Law's failure to accord the child an enforceable support right derived, in part, from a general reluctance to pierce the legal unity of the family. During this era, virtually all income and property rights were vested in the male household head; wives had no more entitlement to support than their children. ${ }^{44}$ Wives and children also had extremely limited inheritance rights. ${ }^{45}$ Indeed, their legal identities were so merged with the family patriarch's that individually they could not maintain a lawsuit, even against a person outside the family. ${ }^{46}$

With the new conditions of the industrial age came a shift away from this perspective on the family. A hundred years after Blackstone, American family law recognized a paternal support obligation that was enforceable on behalf of the child, rather than the public, and which applied whether or not the child was in danger of becoming a public charge. ${ }^{47}$ Like the Common Law approach that it succeeded, this new support obligation was grounded in a particular conception of the family and a larger (although new) network of legal principles. Statutory divorce laws, the Married Woinen's Property Acts, and the

support obligation arose, in part, from the fear that such an enforceable duty would lead to a loss of parental control over children. See Leslie J. Harris et al., Making and Breaking Connections Between Parents' Duty to Support and Right to Control Their Children, 69 OR. L. Rev. 689, 692-95 (1990).

43. See, e.g., John EekelaAr \& Mavis Maclean, Maintenance After Divorce 1-3, 19 31 (1986); tenBroek, supra note 39, at 287-300. As late as 1840, English courts held that "[i]n point of law, a father who gives no authority, and enters into no contract, is no more liable for goods supplied to his son, than a brother, or an uncle, or a mere stranger would be." Mortimore v. Wright, 151 Eng. Rep. 502, 504 (Ex. 1840). Courts sometimes did indirectly provide for the support of children in cases of parental separation through remedies (alimony and necessaries actions) available to a custodial mother. See, e.g., EEKELAAR \& MACLEAN, supra, at 19-22.

44. At marriage, the husband gained control of any property the wife had owned previously; thereafter the wife could not buy or sell land, enter into contracts, or even make a will. See HoMER H. Clark, Jr., The Law of Domestic Relations in the United States 498-501 (2d ed. 1987) [hereinafter Clark, Second Edition]. See also Mary A. Mason, Frou FathrR's Property To Children's Rights: The History of Child Custody in The United States (1994). The husband was also entitled to his wife's and childrens' wages. See id. at 14; Elizabeth B. Warbasse, The Changing Legal Rights of Married Women 1800-61 7-8 (1987).

45. The wife's sole inheritance elaim was dower, which entitled her to a life estate in one-third of her husband's lands. See ClARK, SkCOND EDITION, supra note 44, at 500-01; WARBASSE, supra note 44, at 10-11. Although the Common Law recognized a father's right to his child's labor, it accorded children no inheritance rights except in the case of entailed property. See tenBroek, supra note 39 , at $287-90$.

46. See Clark, FIRST Edition, supra note 12, at 220 (wife unable to sue without joining husband); id. at 233 (minor had to sue through guardian or "next friend").

47. For a description and analysis of the development of American child support law during the nineteenth century, see, for example, tenBroek, supra note 39, at 299-317. English law did not recognize a child support obligation independent of that owed to the custodial parent until the 1920s. See, e.g., EEKELAAR \& MACLEAN, supra note 43, at 19-20. 
alimony claim also developed during this period, ${ }^{48}$ and evidenced the same shift away from the earlier view of the family as a unified legal entity. These new laws transformed the family just as the Poor Laws had transformed the community, with the result that familial obligations based on the claims of affection and morality gave way to legal duties and sanctions.

The new child support obligation reflected some, but not all, of the Poor Law concepts that preceded it. Like the public relief applicant, the child who sought support was required to show dependence and worthiness; children who were emancipated from parental control or who refused to obey reasonable parental commands were no more entitled to pareutal support than the able-bodied were entitled to public funds. ${ }^{49}$ In contrast to the Poor Law approach, however, the new child support laws did not limit the child's claim to subsistence. Instead, courts held that the child was entitled to support that reflected, insofar as the father's current means permitted, the family's income and prior standard of living. ${ }^{50}$ The value of the support obligation was thus left to the discretion of the presiding judge, ${ }^{.51}$ even when initially fixed, the award was subject to modification based on changes in the child's or father's circumstances. ${ }^{52}$

The developing law of spousal support, or alimony, exhibited similar features..$^{53}$ The wife's support claim, like the child's, was based on the marital standard of living, subject to judicial discretion, and modifiable based on changed circumstances. ${ }^{54}$ It was also predicated on worthiness and dependence, failing if the wife was at fault in causing the dissolution of the marriage and terminating upon her remarriage.

48. For historical accounts of these developments, see CARL N. DEgLER, AT OdDS: WOMEN and the Family in America from the Revolution to the Present (1980); Michael Grossberg, Governing the Hearth: LaW and the Family in Nineteenth Century America (1985); WARBaSSE, supra note 44; Richard H. Chused, Married Women's Property Law: 1800-1850, 71 GEO. L.J. 1359 (1983).

49. See, e.g., 67A C.J.S. Parent and Child, $\$ 67$ at 375 (1978) (citing cases and concluding that the "child who voluntarily abandons the parent's home for the purpose of seeking his or her fortune in the world or to avoid parental discipline and restraint forfeits the claim to support").

50. See, e.g, Clark, First EdrTion, supra note 12, at 496.

51. See id. "The amount to be awarded for the support of a child...lies in the sound discretion of the trial court.").

52. See id. at 498-507 (describing traditional modification grounds and procedures).

53. The alimony remedy was originally developed by English ecclesiastical courts to provide recompense to the wife whose husband had both profited from property that she had brought into the marriage and caused its dissolution. For historical accounts of the development of alimony law during the nineteenth century, see CLARK, FirsT EDITION, supra note 12, at 420-22 (describing the development of alimony law in the United States); EEKELAAR \& MACLEAN, supra note 43, at 3-15 (tracing the history of support law in England).

54. See Clark, F1Rst EDItion, supra note 12, at $441-47$ (describing traditional alimony principles). 
The new child support and alimony laws thus effected only a partial transformation of moral duty into legal entitlement. Rather than fixed, unvarying legal obligations, the new laws created equitable remedies, variable over time, and available only to applicants who were both dependent and blameless. Legislative insistence on dependence and virtue as the preconditions for obtaining the new support remedies derived from a variety of sources. One was the traditional Poor Law concept that monetary aid was the sole privilege of the "worthy" poor who could not help themselves,; by imposing obligations directly between family members, the new familial support laws averted some claims on the public purse and ensured a consistent network of public and private obligation. ${ }^{56}$ Another factor was the common status of women and children as economic dependents of the family's male breadwinner. Yet another was the emerging nineteenth century tendency to idealize both women and children as innocents who required protection from worldly concerns. ${ }^{57}$ And the joint economic interests of children and their custodial mother, whose needs and expenditures were inextricably linked, may also have contributed to structural similarity in the rules, as well as to the blurry demarcation between what theoretically were two quite separate entitlements.

The joint economic interests of child and custodial parent also point to another function served by the new child support and alimony laws-that of ensuring fairness between parents. Just as family dissolution created the potential for parents to burden the community with their children's care, it created the potential for one parent to shift all, or a disproportionate share, of that burden to the other. The new child support and alimony laws thus served to allocate the child's expenses between parents as well as to ensure the performance of obligations to the child and community.

The shared economic interests of women and children also produced tension between the laws of alimony and child support. Whenever the custodial mother was blameworthy or remarried, this

55. For analyses of nineteenth century views on the link between poverty and morality, see Gertrude Himmelfarb, The Idea of Poverty: England in the Early Industrial Age (1984); Calvin Woodard, Reality and Social Reform: The Transition from Laissez-Faire to the Welfare State, 72 YALE LJ. 286 (1962).

56. See, e.g., tenBroek, supra note 39, at 291-306 (describing the new familial support laws and their links with contemporary poverty law).

57. On nineteenth century ideals for women, sce NANCY F. CoTT, THE Bonds of Womanhood: "Woman's Sphere" IN New England, 1780-1835 (1977); Deborah Gorham, The Victorian GIRL AND the Feminine Ideal (1982); Ruth H. Bloch, American Feminine Ideals in Transition: The Rise of the Moral Mother, 1785-J815, 4 Feminist STud. 101 (1978); Barbara Welter, The Cult of True Womanhood: 1820-I860, 18 AM. Q. 151 (1966). For children, see JoHN Demos, Past, Present, and Personal: The Family and the life Course in American History 99-107 (1986); Joseph F. KetT, Rites of Passage: Adolescence in AMerica 1790 to THE PRESENT (1977). 
conflict was apparent: in awarding support to a deserving child, no court could prevent its joint utilization by the child's undeserving mother.

Nineteenth century courts seldom explicitly recognized either the apportionment function of child support law or the inherent tension between alimony and child support principles. ${ }^{58}$ We have little evidence of how courts resolved these issues, let alone evidence on typical child support/alimony outcomes. Although late nineteenth century Census Bureau data suggest that alimony was awarded infrequently, ${ }^{59}$ there is a paucity of data on the frequency with which child support was awarded, the level of payments, or the factors that judges deemed important in fashioning an award. The results produced by the new child support laws are largely a mystery right up to the modern era.

\section{The Modern Era: The Guidelines Movement and Growing Disparity in the Status of Spouses and Children}

In the late $1970 \mathrm{~s}$, the federal government began, for the first time, to collect national data on child support awards and payments. The impetus for both this data collection effort and the new wave of child support laws that accompanied it was concern over rising rates of single parenting ${ }^{60}$ and welfare dependence ${ }^{61}$ - the same concern that motivated earlier support laws. ${ }^{62}$ It is thus unsurprising that reforns were initiated

58. See ClARK, FIRST Edition, supra note 12, at 490 ("Notwithstanding a few contrary cases, ... it is usually and properly held that the husband may be ordered to pay child support in the future regardless of the fact that the wife is found guilty of conduct justifying the granting of a divorce to the husband. On this point a sharp distinction has to be made between alimony, as to which fault is relevant, and child support, as to which fault is irrelevant.").

59. See Paul H. Jacobson \& Pauline F. Jacobson, American Marriage and Divorce 127 (1959) (reporting, based on census data, that between 1887 and 1906, 9.3\% of U.S. divorces included provisions for permanent alimony).

60. Between 1960 and 1980, the percentage of American children living in a single-parent household climbed from 8.7\% to $18.3 \%$. See Hernandez, supra note 1, at 65 tbl.3.1. Most single parents are women. U.S. Dep't of Commerce, Bureau of the Census, Statistical ABstract OF THE UNITEd STATES 1995, at 66 thl.79 (1995) [hereinafter Statistical ABSTRACT] (reporting that in $1994,23 \%$ of children lived in a mother-only household, $3 \%$ in a father-only household). The trend toward single motherhood shows no sign of abating. See Roger A. Wojtkiewicz et al., The Growth of Families Headed by Women: 1950-80, 27 DEMOGRAPHY 19 (1990) (describing and analyzing sources of trend toward single motherhood).

61. Concurrently, the proportion of U.S. children who were AFDC recipients rose from $2.5 \%$ in 1948 to $11.3 \%$ in 1973 and program costs rose from $\$ 1.1$ billion in 1960 to $\$ 9.9$ billion in 1976 . See Lowell H. Lima \& Robert C. Harris, The Child Support Enforcement Program in the United States, in Child Support: From Debt Collection to Social Policy 20, 22 (Alfred J. Kahn \& Sheila B. Kamerman eds., 1988). The proportion of children with a deceased parent receiving AFDC decreased from $42 \%$ in 1940 to $2.2 \%$ in 1979 . See id. at 21 .

62. See, e.g., Sanford N. Katz, A Historical Perspective on Child-Support Laws in the United States, in The Parental Child-Support Obligation 17, $19-20$ (Judith Cassetty ed., 1983) (describing reasons for reforms); Harry D. Krause, Child Support Reassessed, in DivORCE REFORM AT THE Crossroads 166, 169 (Herma H. Kay \& Stephen D. Sugarman eds., 1990) ("When 
by the federal government, which today foots most of the bill for welfare payments to children, instead of the states, which traditionally have made child support law. ${ }^{63}$

While sixteenth century lawmakers focused on public support institutions and their nineteenth century counterparts on private support obligations, contemporary policymakers have taken a hybrid approach. Some of the new federal requirements were aimed exclusively at the welfare-eligible population. Others, like the support guidelines requirement, were directed at the entire support-eligible population. ${ }^{64}$ Like earlier support innovations, the new rules reflect and reinforce public assistance principles. Thus, just as contemporary welfare law has abandoned individualized assessment of need in favor of standardized eligibility criteria and grants ${ }^{65}$ Congress required numerical guidelines to replace discretionary decisionmaking. ${ }^{66}$

Of course, the new initiatives also reflect contemporary cultural and economic norms, norms that have shifted dramatically since the nineteenth century. By the time the new support requirements were adopted, women were no longer considered innocents, like children, in need of protection. More importantly, the majority of married women engaged in paid employment, so that wives and children no longer shared a common status as dependents of the family's male breadwinner. ${ }^{67}$ The widespread entry of women into the labor force also substantially lessened the possibility that former wives would wind up on the public dole.

Reflecting these shifts, the new federal requirements applied exclusively to child support, eroding the prior consistency between child and spousal support principles. Although contemporary alimony law

Congress enacted the sweeping legislation to strengthen enforcement of child support obligations across the nation, the primary goal was to reduce the federal cost of the AFDC program.").

63. See, e.g., 42 U.S.C. $\S \S 602-03$ (1994).

64. The Federal Enforcement Initiative of 1974 established the federal Office of Child Support Enforcement and required each state to establish mechanisms for assisting parents in establishing paternity, obtaining child support awards, and enforcing child support obligations. These initiatives were mandated for AFDC recipients, but made available to others. The Child Support Enforcement Amendments of 1984 and the Family Support Act of 1988 mandatcd additional enforcement mechanisms in AFDC cases, including tax refund interception, routine wage withholding, and periodic award updating. For more detailed descriptions of the requirements of the 1974, 1984, and 1988 child support laws, see Lima \& Harris, supra note 61, at 26-41.

65. For descriptions and criticisms of this trend within public assistance law, see KRISTEN Grфnbjerg et al., Poverty and Social Change 133-62 (1978); William H. Simon, Legality, Bureaucracy, and Class in the Welfare System, 92 Y ALE LJ. 1198 (1983).

66. See Family Support Act of 1988, Pub. L. No. 100-485 § 103, 102 Stat. 2343, 2346 (codified as 42 U.S.C. $\$ 667$ (b) (1988)) (guidelines must establish a rebuttable presumption of the appropriate level of support).

67. In $1994,60.7 \%$ of U.S. married women were in the paid labor force. See STATISTICAL ABSTRACT, supra note 60 , at 405 tbl.636. 
has moved toward standards based on need instead of fault, ${ }^{68}$ it is still highly discretionary. ${ }^{69}$ In contrast to the Congressional emphasis on increasing child support levels, the major alimony innovation during this period was the durational award, designed to limit alimony payments to a fixed period of economic "rehabilitation."70

The joint economic interests of children and their mothers have not substantially abated, however. Although the percentage of fathers awarded custody has increased substantially, the number of children who live in a father-only household is still small. ${ }^{71}$ As a result of these conflicting trends, the tension between alimony and child support principles has intensified.

Tension has also developed between the rules governing wives' and children's familial property rights. While the traditional Common Law model still applies to children-they have no claim to their parents' assets whatsoever-marriage is increasingly treated as a relationship that mandates sharing. "Right of election" laws, for example, now grant a surviving spouse an entitlement to a fixed share of the decedent spouse's probate assets; ${ }^{72}$ in inany states, the right of election attaches to a wide range of non-probate property as well. ${ }^{73}$

Even more important is the recent infiltration of community property principles into divorce and inheritance law. The community property concept, a product of the Civil Law tradition that arose on the European continent, treats marital income and assets purchased with that income as the joint property of husband and wife, without regard to

68. See Linda D. Elrod \& Timothy B. Walker, Family Law in the Fifty States, 27 FaM. LQ. 515, 521 \& 534 tbl.1 (1994) (reporting that in 1993,27 states excluded marital fault from consideration in determining alimony).

69. See, e.g., Thomas J. Oldham, Divorce, Separation, and the Distribution of Property $\$ \$ 13-9$ to $13-24.1$ (1994) (comparing state alimony rules); State Divorce Laws (Reference File) Fam. L. Rep. (BNA) 400.001 to 453.001 (1989) (describing alimony rules state-bystate).

70. For descriptions and criticisms of contemporary alimony law, see Ann L. Estin, Maintenance, Alimony, and the Rehabilitation of Family Care, 71 N.C. L. Rev. 721 (1993); Sally F. Goldfarb, Marital Partnership and the Case for Permanent Alimony, 27 J. FAM. L. 351 (1988-89); Joan M. Krauskopf, Rehabilitative Alimony: Uses and Abuses of Limited Duration Alimony, 21 FaM. LQ. 573 (1988); Cynthia Stames, Divorce and the Displaced Homemaker: A Discourse on Playing with Dolls, Partnership Buyouts and Dissociation Under No-Fault, 60 U. CHI. L. REv, 67 (1993).

71. $3 \%$ of U.S. children lived in a father-only household in 1994, as compared to $1 \%$ in 1970. $23 \%$ lived in a mother-only household in 1994 , as compared to $11 \%$ in 1970 . See Statistical ABSTRACT, supra note 60 , at 66 tbl.79.

72. All of the Common Law states except Georgia statutorily grant the surviving spouse an entitlement to a share of the decedent spouse's property. See, e.g., JESSE DukEminier \& STANLEY M. Johanson, Wills, Trusts, AND Estates 483-84 (5th ed. 1995); LaWrence W. Waggoner ET AL., FAMILy Property LAW 473 (1991).

73. See, e.g., DUKEMINIER \& JOHANSON, supra note 72, at 510-12; WAGGONER ET AL., supra note 72 , at 479 . 
title. ${ }^{74}$ While the community property model still applies fully in only nine states, ${ }^{75}$ the model's concept of marriage as a relationship of sharing and equality has made remarkable gains in recent years. ${ }^{76}$ The taxation of marital income and property, as well as spousal interests in Social Security benefits and ERISA pensions, are now governed by sharing principles. ${ }^{77}$ The new Uniform Probate Code elective share rules explicitly attempt to replicate community property principles. ${ }^{78}$ And, although title still determines asset management and control during marriage in most states, it no longer determines asset disposition at divorce; all states that formerly awarded property to the title-holder have adopted some form of "equitable" property distribution $\mathrm{rnle}^{79}$ that permits distribution to the nontitled spouse and typically produces, at least in judicially determined cases, a relatively equal division of assets. ${ }^{80}$

Although the Civil Law model grants children as well as spouses an inheritance entitlement ${ }^{81}$ this type of familial sharing has not yet found

74. For an overview of community property law, see RoBert L MENNELL \& Thomas M Boykoff, COMMUNITY Property (1988). The reasons for the divergence in English and continental European marital property laws remain obscure. See, e.g., Mary M. Wenig, The Marifal Property Law of Connecticut: Past, Present and Future, 1990 WIS. L. REv. 807, 811-16 (1990).

75. Arizona, California, Idaho, Louisiana, Nevada, New Mexico, Texas, and Washington have adopted community property principles. Wisconsin became a community property state in 1986 by adopting the Uniform Marital Property Act (UMPA). See MenNeLL \& BoYKOFF, supra note 74, at 13-17; Wis. Stat. ANN. $\$ 766.001-766.979$ (West 1996).

76. See, e.g., DuKEMINIER \& JoHANSON, supra note 72, at 473 ("[C]ommunity property ideas have made noticeable inroads into the separate property system within the last $\mathbf{5 0}$ years"); Lawrence W. Waggoner, Marilal Property Rights in Transition, 59 Mo. L. Rev. 21, 41-61 (1994) (describing trends in divorce and elective share law that reflect comnunity property concepts).

77. See Dukeminier \& Johanson, supra note 72, at 476-78, 489-91, 1057.

78. See UNIF. Probate Code art. 2, pt. 2, general cmt. (1990) (indicating that reforms were designed "to bring elective-share law into line with the contemporary view of marriage as an economie partnership... applied in both the common-law and community-property states when a marriage ends in divorce"). See also John H. Langbein \& Lawrence W. Waggoner, Redesigning the Spouse's Forced Share, 22 ReAl ProP., PrOB. \& TRUst. J. 303, 304-14 (1987) (discussing history and rationale of forced share statute).

79. See, e.g., OLDHAM, supra note 69 , at $\$ 13-8.1$ n.9 (categorizing state property distribution rules). For descriptions of the historical development of the equitable property distribution concept and the sources of its recent acceptance, see Marsha Garrison, Good Intentions Gone Awry: The Impact of New York's Equitable Distribution Law on Divorce Outcomes, 57 BrooKLYN L. Rev. 621, 627-32 (1991); Mary Ann Glendon, Property Rights Upon Dissolution of Marriages and Informal Unions, in The Cambridge Lectures 245, 245-50 (N. Eastham \& B. Krivy eds., 1981).

80. See Garrison, supra note 10 , at $452-54,500$ (reporting, based on analysis of 323 New York equitable distribution decisions, that net worth was divided relatively equally in $48 \%$ of cases preappeal and 58\% post-appeal); Suzanne Reynolds, The Relationship of Property Division and Alimony: The Division of Property to Address Need, 56 FordHAM L. REv. 827, 854-55 (1988) (reporting, based on evaluation of judicial opinions from six equitable distribution states, that judges rarely deviated from equal property division except in extraordinary cases, which typically involved spousal disability).

81. See, e.g., Joseph Dainow, The Early Sources of Forced Heirship; Its History in Texas and Louisiana, 4 LA. L. REv. 42 (1941); Michael P. Porter, Comment, Forced Heirs, the Legitime and Loss of the Legitime in Lousisiana, 37 TuL. L. REv. 710 (1963). 
a receptive climate in the United States. ${ }^{82}$ Indeed, the one state where there has been legislative activity on children's inheritance rights (Louisiana) is the only state that currently grants children an inheritance entitlement; the entitlement has been under legislative attack for several years. ${ }^{83}$

As a result of these various trends, laws governing economic relations within the family no longer evidence common assumptions and consistent goals. Child support is subject to increasing state regulation aimed at raising support levels, while spousal support is increasingly viewed as a limited, need-based remedy. Spouses are now seen as members of a sharing community who should divide the fruits of their relationship equally, while parents are still treated as autonomous individuals with far more limited obligations.

Today's child support law remains intinately linked with public assistance law. It remains linked-but increasingly at odds-with contemporary rules governing spousal support and spousal property rights. The conflicting visions of family loyalty and obligation that underlie these related areas of law raise fundamental questions about the nature and scope of the child support obligation.

II

The New Child Support Guidelines: Their Development AND EFfects

\section{A. Current Child Support Guidelines: The Basic Model}

When Congress mandated the development of numerical support guidelines in the mid 1980s, it did not specify a particular formula or model. As a result, each state was left to make its own decisions on the normative values that would guide the development of child support policy, how those values would be ordered, and how they would be implemented. Put more concretely, states had to resolve-explicitly or implicitly-these questions: To whom does the income of individual family members belong? Exactly what do parents owe their children

82. Louisiana is currently the only state to grant children an inheritance entitlement. See DUKEMINIER \& Johanson, supra note $\mathbf{7 2}$, at 550 . Recent scholarly commentary is critical of the Common Law approach. See, e.g., Deborah A. Batts, I Didn't Ask to Be Born: The American Law of Disinheritance and a Proposal for Change into a System of Protected Inheritance, 41 HASTINGS LJ. 1197 (1990); Ralph C. Brashier, Disinheritance and the Modern Family, 45 CASE W. RES. L. REv. 83 (1994).

83. See DUKEMINIER \& Johanson, supra note 72, at 550. The Lousiana Supreme Court held that 1989 and 1990 legislation limiting the forced share to children under 23 and handicapped adult children was unconstitutional in Succession of Lauga, 624 So. 2d 1156, 1172 (La. 1993). A constitutional amendment removing protection for forced heirship has since becn introduced in the Louisiana legislature. See Letter from Professor Cynthia Samuel (April 12, 1995) (on file with author). 
and each other? What do they owe the public, that may be forced to pick up the tab for children's needs that parents have failed to meet?

Because none of these questions have uncontroversial answers, one would expect spirited debate and a range of legislative outcomes. In the early days of the guidelines movement, scholars also offered legislators a variety of policy options. Some advocated an "equal outcomes" model aimed at achieving equal living standards for the child and noncustodial parent. ${ }^{84}$ Others advocated a "continuity-of-expenditure" approach, which based the support obligation on typical child-related expenditure within intact, two-parent families. ${ }^{85}$ And others urged that the new guidelines seek, above all else, to ensure that the supported child did not become impoverished as a result of parental separation. ${ }^{86}$ While these approaches garnered the most attention, legislators could also have opted for a utilitarian model or one that aimed at ensuring the child a minimally adequate income. ${ }^{87}$

But while the range of policy options was extensive, policy debate was muted and rarely focused either on the underlying choice between individualist and sharing norms within the family or on the ordering of community and familial obligation. Proponents of the equal outcomes model, for example, argued that the "model focuses upon the child's continuing right to share in the post-divorce economic fortunes of her/his parents in a manner which is consistent with the protections afforded the child in an intact family ...,"88 but failed to note that an

84. See Judith Cassetty et al., The ELS (Equal Living Standards) Model for Child Support Awards, in Essentials of ChILd Support, supra note 22, at 329; Philip Eden et al., In the Best Interests of Children: A Simplified Model for Equalizing the Living Standards of Parental Households, in Essentials of ChILd Support, supra note 22, at 353; lsabel V. Sawhill, Developing Normative Standards for Child-Support Payments, in The Parental. Child-Support Obligation: Research, Practice, and Social Policy 79 (Judith Cassetty ed., 1983).

85. See Robert G. Williams, Development of Guidelines for Child Support Orders: advisory Panel Recommendations and Final Report II (Report to U.S. Dep't of Health \& Human Services, Office of Child Support Enforcement, Sept. 1987); Garfinkel \& Melli, supra note 16 , at 177-78.

86. See The Family Court of the State of Delaware, Procedure in Deciding Child Support Cases, reprinted in American Bar Association, lmproving Child Support Practice I-I69 (1986). See also American Bar Association, America's Children at Risk: A National AGENDA FOR LEGAL ACTION 91-93 (1993) (urging adoption of poverty-focused (Melson type) child support guidehine).

87. See, e.g., Betson, supra note 21, at 9-10 (describing utilitarian support formula); Sawhill, supra note 84, at 99-102 (describing two different minimum income formulae).

88. Judith Cassetty et al., The ELS (Equal Living Standards) Model for Child Support Awards, in EsSENTials of CHILD SUPport, supra note 22, at 329, 332 (emphasis deleted). By contrast, proposals for equalizing spousal living standards post-divorce have been supported with a variety of policy arguments and claims grounded in one or another theory of distributive justice. See, e.g., OkN , supra note 27, at 183 (using contractarian methodology to argue in favor of equalizing postdivorce spousal living standards); Jane Rutherford, Duty in Divorce: Shared Income as a Path to Equality, 58 FORDHAM L. REv. 539, 578 (1990) (advocating equalization of post-divorce spousal living standards "to achieve equality between spouses who have divided their labors during marriage. 
equal outcomes approach conflicts with both the rules governing traditional child support and inheritance law-or that it does comport with the sharing approach increasingly applied to marriage. The principal author of the continuity-of-expenditure approach, on the other hand, offered eight "soup-to-nuts" principles to guide the development of guidelines, but offered no evidence that those principles support continuity-of-expenditure. ${ }^{89}$ And much of the child support literature of this period ignored the basic policy questions altogether, focusing instead on narrow issues of implementation.

One reason for the constricted debate was the speed with which the guidelines movement came to fruition. Prior to 1984, when Congress first required states to adopt advisory support guidelines, only a handful of states and localities utilized guidelines of any description; ${ }^{90}$ within a few months of the October 1989 deadline imposed by Congress, all states had adopted guidelines meeting the federal requirement. ${ }^{11}$ The federal government also contributed to the lack of debate on principles by commissioning an economic analysis of child-rearing costs, relevant only to the continuity-of-expenditure model..$^{92}$ In the end, no state adopted an equal-outcomes, utilitarian, or minimum-income approach. Only three adopted guidelines that took poverty prevention as their basic aim. ${ }^{93}$ All others adopted guidelines utilizing the continuity-ofexpenditure approach. ${ }^{94}$

If spouses have not divided the labor, either because they were not married long enough or because they did not have children, then income sharing should not apply"); Jana B. Singer, Divorce Reform and Gender Justice, 67 N.C. L. REv. 1103, 1114 (1989) (relying on investment partnership theory of marriage as basis for post-divorce income equalization based on marital duration). For an intriguing hybrid approach, see June Carbone, Income Sharing: Redefining the Family in Terms of Community, 31 Hous. L. REV. 359, 392 (1994) (explaining that "[t]he economic community defined by parental obligations toward their children overlays the community defined by the relationship between the parents. Taken together, these overlapping sources of economic interdependence may result in a community that lasts longer than the marriage itself').

89. See Williams, supra note 85 , at 6-8.

90. Delaware had instituted a nonstatutory presumptive statewide guideline as early as 1979; Washington and Wisconsin issued statewide advisory guidelines in the early 1980s; California, Illinois, and Minnesota enacted statutory presumptive guidelines in the year preceding the 1984 Child Support Amendments. See Williams, supra note 16, at 1.

91. See id.

92. See Nancy D. Polikoff, Looking for Policy Choices Within an Economic Methodology: A Critique of the Income Shares Model, in EssEnTIALS OF CHILD SUPPORT, stpra note 22, at 27, 28 (noting that the economic analysis commissioned by the federal Office of Child Support Enforcement (OCSE) "create[s] the appearance of scientific, objective "truth"" and is "given heightened validity by virtue of OCSE's involvement").

93. Delaware, Hawaii, and West Virginia adopted guidelines of this type. See MuNSTERMAN, supra note 14 , at 12 .

94. See Polikoff, supra note 92 , at 11-12. 
The continuity-of-expenditure model was expressed in two different guideline formulae.95 Under the "percentage-of-obligorincome" formula, ${ }^{96}$ the child support obligation is stated as a percentage that varies with the number of children to be snpported. ${ }^{97}$ The percentages are based on a variety of consumer surveys and purport to represent typical expenditure patterns in intact families. ${ }^{98}$ The applicable percentage is applied to the noncustodial parent's income to produce a child support value. ${ }^{99}$

The "income-shares" formula similarly utilizes standard percentages ${ }^{100}$ that are applied to parental income and vary depending on the number of children. ${ }^{101}$ But an income shares formula typically requires more information and arithmetic. The percentages are calculated to exclude child-care costs and any costs associated with extraordinary medical care on the theory that these, potentially very

95. As of 1994, one or another of these models was in use in 45 states. See Williams, supra note 16, at 6-7 (reporting current guideline model on a state-by-state basis). Not all state guidelines are "pure" examples of the income shares or percentage-of-income models. The New York guideline, for example, utilizes standardized percentages that do not vary by income levcl, but requires individualized calculations of child care and extraordinary medical expenses. See N.Y. DoMs. REL. L. §§ 236B.1-b(c)(4)-(5) (McKinney Supp. 1994). It also requires a calculation that includes the custodial parent's income, but, unless combined parental income excceds the statutory income cap, the custodial parent's income has no effect on the child support award. See id. at $\S$ (c)(2). See also Williams, supra note 16, at 6 (categorizing New York guideline as percentage-ofobligor income type because inclusion of custodial parent income has no mathematical effect on support value).

96. For accounts of this model and its development, sce GARFINKEL, supra note 22, at 88-101; Garfinkel \& Melli, supra note 16, at I64-65.

97. The percentages are $17 \%$ of noncustodial parent income for one child, $25 \%$ for two, $29 \%$ for three, $31 \%$ for four, and $34 \%$ for five or more. See Williams, supra note 16, at 5 .

98. The percentages utitized in the percentage-of-obligor income formula were based on a review of the then existing research conducted by economist Jacques van der Gaag. See Jacques van der Gaag, On Measuring the Cost of Children, 4 CHILdREN \& Youth SeRvices Rev. 77 (1982). But, according to one of the authors of the formula, given the "enormous" range of estimates, this economic data provided "only a starting point for determining the percentages...." GarfiNKEL, supra note 22 , at 89.

99. In many versions of this model, the percentages do not apply to income above a certain income "cap." For state-by-state comparisons, see Dodson \& ENTMACHER, supra note 14, and MUNSTERMAN, supra note 14.

100. Unlike the percentage-of-obligor-income formula, the income shares percentages were based on the one study believed to be most reliable. See Thomas J. EsPEnshade, Investing in Children: New Estimates of Parental Expenditures (1984). For a description of how the Espenshade study was used to derive the percentages, see Williams, supra note 85, at 67-80, 12940. Some income shares guidelines have since been updated to take account of more recent data developed by the federal Offico of Child Support Enforcement based on a requirement in the Family Support Act of 1988 (Pub. L. No. 100-485 § 128). See David M. Betson, University of Wisconsin INSTITUTE for Research on Poverty, ALternative Estimates of the Cost of ChILdREN From THe 1980-86 Consumer EXPenditure SURvey (1990).

101. See, e.g., Wrlliams, supra note 85, pt. Il, at 65-80 (describing development of this model); Robert G. Williams, Guidelines for Setting Levels of Child Support, 21 FAM. L.Q. 281, 291-95 (1987) [hereinafter Williams, Guidelines] (same). 
large, expenses are too variable to permit standardization. ${ }^{102}$ The percentages are also variable and, in most versions, regressive, with lower percentages applicable to higher incomes. ${ }^{103}$ The support calculation takes into account the incomes of both parents, with the final award obtained by prorating the percentage-based support obligation plus child-care costs according to the percentage of family income contributed by each. ${ }^{104}$ Awards calculated under income shares guidelines thus represent a compromise between standardization and individualized case processing.

In sum, continuity-of-expenditure guidelines, although motivated by a common aim, vary substantially in their methodology, complexity, and results. The same facts, about the same family, may yield an altogether different child support award. ${ }^{105}$

In contrast to the diversity of continuity-of-expenditure formulae, the poverty prevention approach is reflected in only one guideline formula, the so-called "Melson" model. This formula, pioneered in Delaware by Judge Elwood F. Melson, Jr. for use in his own courtroom, was the first guideline to be adopted statewide. In revised form, it is still in effect in Delaware and has been adopted in three other states. ${ }^{106}$ The formula establishes "primary support" values designed to meet the minimum needs of one adult and one or more children. ${ }^{107}$ The adult primary support value is first subtracted from each parent's income; the remainder is then applied, in proportion to the parents' relative incomes, to the basic child support obligation. ${ }^{108}$ The Melson formula does not take poverty prevention as its only goal, however. If the child support obligor still has available income, a fixed percentage of that income, based on those utilized by the percentage-of-obligor-income model, is

102. See Williams, supra note 85 , at 77 ; Goldfarb, supra note 22 , at 332-34.

103. See, e.g., Williams, Guidelines, supra note 101, at $292-93$ tbls. 2 \& 3. In some states the percentages also vary depending on the ages of the children. See David Amaudo, Deviation from State Child Support Guidelines, in Next Generation, supra note 16, at 85, 87 tbl.1.

104. See Williams, Guidelines, supra note 101, at 293.

105. For examples and analyses, see Dodson \& ENTMACHER, supra note 14, at 34 tbl.4F; Maureen A. Pirog-Good, Child Support Guidelines and the Economic Well-Being of Children in the United States, 42 FAM. REL. 453, $455-57$ tbl.1 (1993). See also Williams, Guidelines, supra note 101, at 306,308 , figs. 3 \& 4 (graphically showing child support percentages by obligor income under different guideline types).

106. As of 1994, Hawaii, Montana, and West Virginia utilized a guideline based on the Melson formula. See Williams, supra note 16 , at 7.

107. As of 1994 , the primary support values were $\$ 220$ per month for the first child, $\$ 165$ per month for each of the second and third children, and $\$ 110$ per month for each additional child. See id. at 6 .

108. The basic support obligation equals the sum of the children's primary support needs plus actual, work-related child care expenses. Extraordinary medical expenses are similarly prorated. See id. 
then added to the basic support obligation. ${ }^{109}$ The Melson formula thus seeks to avert impoverishment of the noncustodial parent and the child, in that order. A secondary goal is income sharing in relation to expenditure patterns within the intact family.

Although a poverty-prevention guideline could easily vary from the Melson formula - for example, by giving equal or greater priority to the needs of the child as compared to those of the noncustodial parent, or by taking poverty-prevention as a sole aim-no American jurisdiction has adopted any other type of poverty-prevention formula. All of the states have thus far adopted either the Melson formula or a variant of the continuity-of-expenditure model. Thus despite the fact that the guidelines legislation evidenced no central philosophy and required no particular approach, all state guidelines today aim, to some extent, at maintaining continuity of child-related expenditure; in a handful, poverty-prevention is also an articulated goal.

\section{B. What the Guidelines Have Accomplished}

Although research reports analyzing the impact of the new guidelines are still few in number, available reports suggest that child support awards remain highly variable ${ }^{10}$ and that the average value of awards has increased modestly but not dramatically. ${ }^{11}$ Despite

109. In 1994, the percentages used in Delaware were " 18 percent for one child, 27 percent for two children, 35 percent for three children, 40 percent for four children, 45 percent for five children, and 50 percent for six or more children." Robert G. Williams, Implementation of the Child Support Provisions of the Family Support Act: Child Support Guidelines, Updating of Awards and Routine Income Withholding, in CHILd SuPPORT AND ChI WD Well-BeING 93, 98 (Irwin Garfinkel et al. eds., 1994).

110. See Marilyn L. Ray, New York State Child Support Standards Act Evaluation ProjeCt REPORT 54 (1994) (22\% of sample child support orders followed guidelines); Marygold S. Melli \& Judi Bartfeld, The Wisconsin Percentage of Income Standard: How is it Being Used?, 11 Wis. J. FAM. L. 60, 61 tbl.1 (1991) (51\% of sample child support orders followed guidelines; no determination possible in $25 \%$ of cases); Kathryn D. Rettig et al., Impact of Child Support Guidelines on the Economic Well-Being of Children, 40 FAM. REL. 167, 170 (1991) (12.6\% of sample courtordered child support awards followed Minnesota guidelines); Nancy Thoennes et al., The Impact of Child Support Guidelines on Award Adequacy, Award Variability, and Case Processing Efficiency, 25 FAM. LQ. 325, 339-40 (1991) (reduction in award variability occurred following introduction of guidelines in two of three states for low-income families, one of thiee for upper-income families, and in no state for middle-income families). For a descriptive summary of state data on award variability under current guidelines, see David Arnaudo, Deviation from State Child Support Guidelines, in NeXT Generation, supra note 16 , at 88-94.

111. The largest and most detailed study to date is described in Thoennes, supra note 110, at 33233,336 (reporting that average post-guidelines award was $15 \%$ higher than pre-guideline average across three-state sample). In only one of the three research states-that state with the lowest preguideline award levels-did all income groups experience siguificant increases in the level of child support attributable to the introduction of mandatory guidelines; in one state no income group did. See id. See also Commonwealth of Virginia Dep't of Social Services, The Impact of Child Support Guidelines on THE Level of Child Support Awards iN Virginia 11 (1990) (reporting that mean court child support award was $17 \%$ higher when advisory guideline amount was used); Vermont Agency of Human Services, in Support of Our Children: A Survey of 
predictions by some experts that guidelines would triple child support values, ${ }^{112}$ increases to date have fallen far short of that level. In some states, average award levels apparently did not mcrease at all after guidelines were introduced. ${ }^{113}$ In others, increases were registered by some income groups but not others. ${ }^{114}$ Moreover, a significant proportion of the increase in average child support values that researchers have noted inay simply be due to the imposition of token, rather than zero-dollar, awards in cases of unemployed or female noncustodial parents. ${ }^{115}$ While these results do not suggest that children are worse off under current guidelines than they were under discretionary child support laws, they do suggest that the new rules have not dramatically improved the lot of children eligible for child support. ${ }^{116}$

Child Support Orders and Divorced Parents in Vermont (1989) (estimating that guidelines increased child support awards in divorce cases by an average of $23.6 \%$; percentage of obligor income awarded in child support not reported); Kathryn Stafford et al., The Effects of Child Support Guidelines: An Analysis of the Evidence in Court Records, 11 LIFESTYLES: FAM. \& EcoN. Issues 361, 376 (1990) (reporting that after adoption of guidelines weekly mean child support amount, in constant dollars, increased by $21 \%$ in thrce Ohio counties; percentage of obligor income awarded in child support not reported).

The only study to report a dramatic post-guidelines increase in child support values appears to be in error. See Ginny Fay \& Emily Read, Chmb Support In Alaska: AN Evaluation of the EFFectiveness AND 1MPACT OF Alaska's Child Support Guidelines 38, 63 tbl.19 (1991) (reporting that the average support award increased by nearly $100 \%$ after the introduction of guidelines). Fay and Read rely on a comparison of post-guidelines awards with pre-guidelines award averages reported in Bareara BAKER, Family Equity at IsSUE: A STUDY of THE Economic Consequences of Divorce on Women AND ChILdRen (1987). However, they appear to have misread Baker, who reports only a mean monthly child support award per child. See id. at ii, 13-14. She does not report a mean total child support award except for one-child families. That one-child mean, updated from 1985 dollars to constant 1989 dollars, is $16 \%$ less tban the post-guidelines onechild mean reported by Fay \& Read.

112. See Ron Haskins et al., U.S. Dep't of Health \& Human Services, Estimates of National Child Support Collections Potential and the Income Security of FemaleHEADED FAMILIES v, 29 (1985) (making "moderate" estimate that application of either of two guideline models would increase child support collection potential by 350\%). For a more conservative estimate, see Irwin Garfinkel et al., Child Support Guidelines: Will They Make a Difference?, 12 J. FAM. IssuES 404, 426 (1991) (predicting that introduction of guidelines would increase child support award levels between $77 \%$ and $88 \%$, depending on the guideline adopted).

113. Thoennes, supra note 110 , at 336 (reporting that, in Illinois, guidelines did not significantly increase award levels in any income group when differences in employment status of pre-and postguideline samples were taken into account).

114. See id. tbl.6 (reporting that in Colorado the average award did not increase signifieantly in either the lower or upper-income group; in Illinois average award did not increase significantly at the middle or upper-income level, and the low-income level increase was not statistically siguificant).

115. See P. Bushard, Time Series Impact Assessment of Child Support Guidelines: Support Awards in Shared Custody Divorces (1988) (unpublished Ph.D. dissertation, Arizona State University), cited in Thoennes, supra note 110, at 343 (conclnding that 15\% increase in snpport levels in shared custody cases after adoption of Arizona child support guidelines was entirely due to a reduction in zero-dollar awards).

116. For a description of the research findings under discretionary standards, sce Garrison, supra note 79, at $633 \mathrm{n} .43$ (living standards), 721 tbl.56 (per capita income). 
To be sure, some of the reasons for these results lie outside the reach of any law governing child support values. Variation in award levels, for example, results in large part from the process of individual negotiation that determines the vast majority of child support awards. ${ }^{117}$ Many parents who negotiate support awards are poorly informed about the relevant legal standards. ${ }^{118}$ In a large, and apparently growing, proportion of the cases, lawyer representation is available to only oneor neither-parent. ${ }^{119}$ Under these circuinstances, the resources ${ }^{120}$ and attitudes ${ }^{121}$ of each parent may play important roles in determining child support outcomes and produce results that bear little relationship to the outcomes that lawmakers intended to achieve. Aggregate outcomes are also affected by the failure of many support-eligible parents to seek awards. More than four out of ten mothers-and more than threequarters of those never-1narried-have not obtained a child support award. ${ }^{122}$ Some of these mothers could not find the father or believed

117. Experts generally estimate that no more than $10 \%$ of divorce actions involve formal adjudication. See, e.g., Marc Galanter, Why the "Haves" Come Out Allead: Speculations on the Limits of Legal Change, 9 LAw \& Soc'y Rev. 95, 108 (1974). However, recent research suggests that the rate of formal adjudication may vary substantially from one state to the next. Compare Eleanor E Maccoby \& Robert H. Mnookin, Dividing the Child: Social and Legal DilemMAS OF CUSTODY 159 (1992) (reporting formal adjudication of approximately $1.5 \%$ in California sample of divorce actions involving minor children), with Margaret F. Brinig \& Michael V. Alexeev, Trading at Divorce: Preferences, Legal Rules and Transaction Costs, 8 Oiro ST. J. ON DisP. Resol. 279, 294 tbl.1I (1993) (reporting that 5.38\% (Wisconsin) and 10.13\% (Virginia) of sample divorce actions went to trial).

118. See, e.g., Howard S. Erlanger et al., Participation and Flexibility in Informal Processes: Cautions from the Divorce Context, 21 LAw \& SoC'Y Rev. 585, 600 (1987) (In divorce negotiations, "legal constraints are decidedly less important [than emotional and financial issues]"); Herbert Jacob, The Elusive Shadow of the Law, 26 LAW \& Soc'y REv. 565, 584-85 (1992) ("In divorce it seems that attorneys do not typically conduct the negotiations. ... [A]greements arc often worked out in private with very little apparent law talk.").

119. See generally Jessica Pearson, Ten Myths About Family Law, 27 FAM L.Q 279, 281-82 (1993) (reviewing research); Jane C. Murphy, Access to Legal Remedies: The Crisis in Family Law, 8 B.Y.U. J. PUB. L. 123 (1994) (same).

120. See, e.g., Melli, supra note 10 , at $1155-56$ (reporting that divorcing couples consistently express concern about legal fees and sometimes settle in order to avoid additional expense); Thoennes, supra note 110 , at $340-41$ tbl.10 (finding that legal representation was significantly correlated with value of child support award at all income levels).

121. One group of researchers, for example, found that the parties' attitudes toward the divorce was a factor "of some significance" in determining child support outcomes. Custodial parents who were reluctant to end the marriage and/or whose spouses were impatient to do so obtained significantly better child support awards than the mean of the group. See Melli, supra note 10, at 1168-71. See also Jay D. Teachman, Socioeconomic Resources of Parents and Award of Child Support in the United States: Some Exploratory Models, 52 J. MARRIAGE \& FAM. 689, 697 tbl.3 (1990) (reporting based on data from National Longitudial Study of the High School Class of 1972 that "both the capacity to negotiate and motivation are at work determining the likelihood and size of [child support] awards").

122. See U.S. Dep'T of Commerce, Bureau of the Census, Child Support for Custodial Mothers AND Fathers: 1991, at 6 (Current Population Reports No. P60-187) [hereinafter 1991 CHILD SUPPORT REPORT] (reporting that $56 \%$ of custodial mothers, $41 \%$ of custodial fathers, and $27 \%$ of never-married mothers had been awarded child support in 1991). 
that he was unable to pay; others report that they simply did not want to pursue an award. ${ }^{123}$ Thus, even with an excellent rule, the attitudes and behavior of custodial parents may preclude excellent results.

Moreover, even the best possible child support rule is powerless to ensure that children are adequately supported when family income is inadequate. Children who were poor before family dissolution (or nonformation) will remain poor. Because both divorce ${ }^{124}$ and nonmarital childbearing ${ }^{125}$ are more common among low-income families, the extent of unpreventable poverty in the support-eligible population is substantial. ${ }^{126}$ The problem of preexisting poverty is also exacerbated by the loss of economies of scale that accompanies family break-up. Two households cannot live as cheaply as one; thus the federal poverty level for a family of three is approximately $50 \%$ less than that of a family of one and a family of two. ${ }^{127}$ For the family that

123. See id. at 12 tbl.F (showing that, in 1991, 34.0\% of custodial parents without support orders reported simply that they "did not pursue a child support award;" $17.5 \%$, that they "did not want child support;" $16.5 \%$, that they believed the "other parent [was] unable to pay;" and $17.5 \%$, that they were "unable to locate [the] other parent"). Recent research suggests that some welfare mothers forgo a formal child support award in order to maximize their family's potential social and economic gains from both the AFDC program and the father. See Kathryn Edin, Single Mothers and Child Support: The Possibilities and Limits of Child Support Policy, 17 CHILDREN \& YOuTH SERvices Rev. 203, 215-16 (1995).

124. See, e.g., William J. Goode, World Changes in Divorce Patterns 152-57 (1993) (summarizing research on the relationship between socioeconomic class and divorce rates); U.S. Dep'T of Commerce, Bureau of the Census, Family DisRuption and Economic Hardship: The ShoRT-RUN PICTURE FOR CHIIDREN 2 (Current Population Reports, Series P-70, No. 23) (1991) (reporting that, among families with children, $21 \%$ of those that experienced the loss of the father from the household during a two-year survey period were already poor, a poverty rate double that of stable two-parent families in the survey); U.S. Dep'T of COMMERICE, BuREAU of the CENSUS, Studies in Household and Family Formation: IVhen Households Continue, Discontinue, AND Form 18-21 (Current Population Reports, Series P-23, No. 180) (1992) (reporting that divorce is approximately twice as likely among sample couples with incomes below the poverty line as compared to others); id. at 19 tbl.1; Rand D. Conger et al., Linking Economic Hardship to Marital Quality and Instability, 52 J. MARRIAGE \& FAM. 643, 653-54 (1990) (finding that instability in husband's work, a drop in family income, and a low ratio of family income to family needs increases risk of divorce).

125. See, e.g., Elizabeth Phillips \& 1rwin Garfinkel, Income Growth among Nonresident Fathers: Evidence from Wisconsin, 30 DemograpHy 227, 234 tbl.2 (1993) (showing that $41 \%$ of nevermarried nonresident fathers with tax records were poor in year before support action, as compared to $19 \%$ of divorced nonresident fathers).

126. See Marsha Garrison, Child Support and Children's Poverty, 28 FAM. LQ. 475, 492-503 (1994) (reviewing Andrea H. Beller \& John W. Graham, Small Change: The Economics of Child Support (1993) and Donald J. Hernandez, America's Children: Resources From FAMILY, GOVERNMENT AND THE ECONOMY (1993)) (analyzing limitations of child support policy as a means of curbing childhood poverty). The problem is not unique to the United States. See Oldham, supra note 11, at 694-95 (describing empirical data on percentages of low-income child support obligors in Australia and the U.K.).

127. See Statistical ABSTRACT, supra note 60 , at 427 (reporting poverty threshold of $\$ 6800$ for one individual under 65 and $\$ 8794$ for two persons with a householder under 65 ). See also Betson, supra note 21, at 4 (noting that, if family's total income is unchanged by divorce, its overall standard of living must necessarily fall due to loss of economies of scale and shared goods). 
had barely averted poverty when together, dissolution ensures that some, if not all, family members will thereafter be poor. ${ }^{128}$

Because of these factors limiting the extent to which a child support rule can achieve its intended results, the new support guidelines must be judged primarily on the basis of the results sought rather than those achieved. But today's guidelines appear to be lacking even by this measure. First, the level of support mandated frequently does not protect children from poverty. One recent review, which evaluated all state guidelines in effect in 1989-90, concludes that none required lower-income noncustodial parents to provide enough child support to ensure either a poverty-level or a "minimuin decent living" standard for two children. ${ }^{129}$ While this goal might have been unobtainable in soine of the cases to which the guidelines were applied, in others it was not. A significant number of states also failed to ensure that children in middle-income families enjoyed a minimuin decent living standard. ${ }^{130}$ Moreover, awards calculated under the gnidelines produced a dramatic decline in children's living standard as compared to that of the noncustodial parent. On average, awards under the guidelines reviewed caused children's living standards to decline by $26 \%$ while noncustodial parents' improved by $34 \% .^{131}$

128. See, e.g., Pirog-Good, supra note 105, at 459.

129. See G. Diane Dodson, Children's Standard of Living Under Child Support GuidelinesWomen's Legal Defense Fund Report Card, in Next Generation, supra note 16, at 95, 98. See also Donna H. Christensen \& Kathryn D. Rettig, Standards of Adequacy of Child Support Awards, $16 \mathrm{~J}$. DIVORCE \& REMARRIAGE 19, 38 (1991) (reporting that application of Wisconsin guideline would have provided poverty level living standard for only $42.3 \%$ of case sample); Pirog-Good, supra note 105 , at 459 (using one estimate of family expenditure for a low income family, guidelines in 14 states failed to produce an adequate award; using another estimate all guidelines fell short); Ellen $B$. Zweibel \& Richard Shillington, Child Support Policy: Income Tax Treatment and Child Support Guidelines (1994), in Carl E SchneIder \& Margaret F. BRINIG, AN INvitation To Family Law: Principles, Process and Perspectives 972, 978 tbl.4.l (1996) (reporting that under both income shares and Melson formula more than $75 \%$ of low-income custodial parents would have incomes below poverty line).

130. See Dodson, supra note 129 , at 98 . Eighteen state guidelines failed to provide a minimum decent living standard using one middle-income scenario; 21 , using another such scenario; 31 , using a third; and 47, using a fourth. "Minimum decent standard of living" was defined as $150 \%$ of the federal poverty level. See id. at 97 . See also Pirog-Good, supra note 105, at 459 (using one estimate of family expenditure for a middle income family, guidelines in 10 states failed to produce an adequate award; using another estimate all guidelines fell short); Zweibel \& Shillington, supra note 129, at 978 tb1.4.1 (reporting that $31 \%$ of low middle income custodial parents did not attain poverty level using both income shares and Melson formulac).

131. See Dodson \& ENTMACHER, supra note 14, at 32 tbl.4-E. See also FAy \& READ, supra note 111, at 7,61 tbl.17 (noting a similar pattern in Alaska); MACCOBY \& MNOOKIN, supra note 117, at 257 (reporting that divorced mothers experienced a living standard decline and fathers an improvement under California's child support guidelines); Betson, supra note 21, at 12 tbl.3 (reporting that when noncustodial parent earns $\$ 20,000$ and custodial parent earns $\$ 10,000$, income shares guidelines produce ratio of post-divorce to pre-divorce scaled surplus income of 1.24 for noncustodial houseliold and .41 for custodial household); Rettig, supra note 110 , at 171 (reporting, based on analysis of Minnesota child support cases decided under guidelines, median income-to- 
Today's guidelines fail to meet the Congressional goals that motivated them. They have not significantly raised award levels; they fail to prevent children's poverty even when it is preventable; and they distribute the burden of family dissolution so that children are typically its primary victims.

\section{The Reasons for the Results}

The failure of current guidelines to ensure that children do not bear the brunt of family dissolution is sobering but not surprising: Current guidelines were not designed either to achieve a minimum decent living standard for children or to ensure that the economic burden of family dissolution is equitably distributed; the methodology that they employ is inherently ill-adapted to accomplishing either of these other goals.

The estimates of child-related expenditure on which current guidelines rely are based on predictions of how much more income a two-parent household, with a given level of expenditure, would need in order to add a new family member and maintain its standard of living. But single parents appear to spend a considerably larger fraction of their incoines on children than do two-parent households. ${ }^{132}$ Moreover, more than $90 \%$ of typical family expenditure represents goods such as housing, transportation, and utility payments that cannot easily be allocated to specific family members. ${ }^{133}$ The estimates thus describe only the marginal, or extra, costs associated with a new family member, not the per person allocation of family resources. ${ }^{134}$

These marginal cost estimates all derive from one or another "household equivalence scale," devised by economists to permit living standard comparisons when households are not the same size. ${ }^{135}$ These

needs ratio at date of divorce of 1.77 for custodial households and 1.92 for noncustodial households); Zweibel \& Shillington, supra note 129, at tbl.4.2 (showing disparities in living standards of noncustodial and custodial households under income shares and Melson support formulae).

132. See BETSON, supra note 100, at 55 (based on 1980-86 CPS data, proportion of total expenditure spent on two children was $35 \%$ in a two-parent and $53 \%$ in a one-parent family); Edward P. Lazear \& Robert T. Michael, Allocation of InCOME Within the Household 97 (1988). But see U.S. DeP'T OF Agriculture, Family Economics Research Group, EXPENDITUREs ON A Child By FaMilies 10 (1992) (concluding that "expenses on a child in singleparent households are slightly higher than those in two-parent households, probably because of economies of scale").

133. See BETSON, supra note 100, at 3 (based on 1980-81 Consumer Expenditure Survey, 90\% of total expenditures in families with children represent commodities that could not be assigned to either children or adults based on the nature of the good).

134. The estimates also rely exclusively on market purchases, ignoring the cost of parental time devoted to child care that might have been utilized for income production. See id at 6-8. See also Garfinkel \& Melli, supra note 60, at 168.

135. For detailed discussions of the limitations of household equivalence scales, see Charles Blackorby \& David Donaldson, Adult-Equivalence Scales, Interpersonal Comparisons of Well-Being, and Applied Welfare Economics, in INTERPERSONAL COMPARISONS OF WELL-Being 164 (Jon Elster 
scales were not intended as a basis for assessing child support, and have major limitations when used for that purpose. ${ }^{136}$ Although their assumptions and results vary substantially, ${ }^{137}$ such scales do offer a basis for predicting how much more income a family (say, John and Mary) will need in order to add a new member (Baby, for example) and maintain its current living standard. ${ }^{138}$ They also enable us to predict Baby's standard of living when she joins the family. ${ }^{139}$ But they tell us nothing about Baby's living standard if her parents separate, dividing the family and its income. ${ }^{140}$ Unless the same income base is available in Baby's new household-an unlikely result given prevailing custody patterns and gender-based wage differentials-her living standard must, of necessity, change. ${ }^{141}$ Current child support guidelines thus "severely penalize children for being in the custody of a parent who has less income, and reward them for living with the parent who has more."142

\& John E. Roemer eds., 1991); Angus S. Deaton \& John Muellbauer, On Measuring Child Costs: With Applications to Poor Countries, 94 J. PoL. ECON. 720 (1986); Arthur Lewbel, Household Equivalence Scales and Welfare Comparisons, 39 J. PuB. EcoN. 377 (1989); Julie A. Nelson, Household Equivalence Scales: Theory Versus Policy?, 11 J. LAB. Econ. 471 (1993).

136. See, e.g., Nelson, supra note 135, at $474-75$ ("The practical usefulness [of household equivalence scales] in designing child support policy is limited.").

137. One recent comparative analysis, for example, produced estimates of child-related expenditure in a one-child, two-parent family ranging from $11 \%$ to $33 \%$ depending on which of four alternate calculation methods was ntilized. See BETSON, supra note 100, at 178-92 (providing estimates for a family of two parents and one eight-year old child with a $\$ 25,000$ expenditure level based on 1980 s Consumer Expenditure Survey data). The $11 \%$ estimate was derived using the socalled "Barten-Gorman model," id. at 192 tbl.F15; the 33\% estimate using the "Engel model," id. at $178 \mathrm{tbl.F1}$; the "Rothbarth model" produced an estimate of $25 \%$, id. at 188 tbl.F11; the 1SO-PROP model an estimate of $18 \%$, id. at 182 tbl.F5. See also Bassi \& Barnow, supra note 21 , at $480-83,485$ tbl.1 (describing methodologies and showing range of estimates of child-related expense using various methodologies for different family types).

138. See, e.g., Betson, supra note 21, at 3; Blackorby \& Donaldson, supra note 135, at 168; Nelson, supra note 135 , at 473 .

139. However, because household equivalence scales typically rely on the assumption that household members enjoy equal living standards, they may dramatically inflate or underestimate the well-being of specific individuals. See, e.g., AMARTYA SEN, INEQUALITY REeXAmINEd 122-25 (1992) (discussing how household equivalence scales fail, in various soeieties and cultures, to aecount for dramatic inequalities in intra-family wellbeing based on gender). For an exception to the equal well-being assumption, see LAZEAR \& MrCHAEL, supra note 132, at 5.

140. See, e.g., Panos Tsakloglou, Estimation and Comparison of Two Simple Models of Equivalence Scales for the Cost of Children, 101 Econ. J. 343, 354 (1991) ("[T] he models ... are concerned with the effect of children on the welfare of their parents but do not tell us anything about the welfare of the children themselves.").

141. See, e.g., Bassi \& Barnow, supra note 21, at 494-95 ("Requiring the noncustodial parent to maintain his or her rate of expenditures on the child is likely to result in the child having a lower standard of living and might still leave the noncustodial parent with a highcr standard of living than he or she enjoyed prior to the dissolution.").

142. Betson, supra note 21, at 18-19. 


\section{Why the Success of the Continuity-of-Expenditure Model?}

Given the deficiencies of the continuity-of-expenditure model as a means of remedying the low support levels that were the primary motivation behind the guidelines requirement, one obvious question is why legislatures chose this approach. The deficiencies could easily have been predicted by anyone with a guideline and calculator in hand; alternatives were available, most of them no more complex than continuity-of-expenditure guidelines, and some of them are arguably simpler. ${ }^{143}$

At first glance, the selection of the continuity-of-expenditure approach over its competitors is also an odd one. After all, the amount that a parent did spend on his or her children when the family was intact bears no obvious or necessary relation to what he should spend now that the family is separated. Traditional child support law, under which the support award is based on an assessment of needs, resources, and the child's prior living standard, implicitly recognized that the past offers only a partial guide to the determination of a fair support value for the future. Moreover, for the rapidly growing segment of the supporteligible population born outside of marriage, there is no past. ${ }^{144}$ Most nonmarital children have never lived in an intact household. ${ }^{145}$ For these children, the replication of past expenditure patterns is pure fiction.

143. Some proponents of continuity-of-expenditure type guidelines have been quite frank about the limitations inherent in the underlying methodology. In describing the development of the percentages utilized in the "percentage-of-obligor-income" formula, for example, its primary authors acknowledge that:

[u]ltimately, the determination of how much the nonresident parent should pay depends upon value judgments on balancing conflicting objectives: providing well for the children, minimizing public costs, and retaining incentives with a decent standard of living for the nonresident parent. Establishing a child support standard cannot be a purely scientiflc exercise.

Garfinkel \& Melli, supra note 16 , at 168.

144. $30.1 \%$ of U.S. births were to never-married mothers in 1992 , as compared to $10.7 \%$ in 1970. Statistical ABSTRACT, supra note 60, at 77 tbl.94. As a result of this trend, the percentage of child support-eligible mothers who have never been married has risen rapidly. Compare 1991 CHILD SUPPORT REPORT, supra note 122, at 3 tbl.A (showing that, in 1991, 25.9\% of custodial mothers had never been married), with 1978 CHILD SUPPORT REPORT, supra note 5, at 3 tbl.B (showing that, in $1978,19 \%$ of custodial mothers had never been married).

145. See, e.g., Larry L. Bumpass \& James A. Sweet, Children's Experience in Single-Parent Families: Implications of Cohabitation and Marital Transitions, 21 FAM. PLAN. PerSP. 256, 256 (1989) (reporting that only 27 percent of nonmarital births betwcen 1970 and 1984 were to cohabiting couples); Andrew J. Cherlin, The Weakening Link Between Marriage and the Care of Children, 20 FAM. PlaN. PERSP. 302, 303 (1988) (estimating that 22\% of white and $12 \%$ of black children under six living with an unmarried mother have an adult nonrelative in the home). By contrast, in Sweden a higher proportion of births are nonmarital (in 1986,48.4\%), but most of the mothers are living with the child's father. See Mary A. Glendon, The Transformation of Family Law: State, Law, AND FaMily in the UNITEd States aNd Western EuRope 273 (1989); David Popenoe, Beyond the Nuclear Family: A Statistical Portrait of the Changing Family in Sweden, 49 J. MARRIAGE \& FAM. 173, 175-76 (1987). 
One probable reason for the model's success is simply false advertising. Its proponents claimed that continuity-of-expenditure formulae would significantly raise support levels and thus benefit children, their custodial parents, and the public; they also claimed that these improvements could be achieved with awards that tax noncustodial parents with payments that do not exceed their prior child-related expenses. ${ }^{146}$ These claims, that offer benefits to all and harm none, surely played a role in the continuity-of-expenditure model's political success.

The model's explicit segregation of child-related and parental expenditure provides another reason for its success. With alimony increasingly viewed as a temporary, need-based remedy, policy makers may have found it "culturally unacceptable" to define the child support obligation in a way that links a benefit to the child with an improvement in the economic circumstances of a former spouse. ${ }^{147}$ The continuity-of-expenditure model thus reflects, and reinforces, the increased tension between alimony and child support.

The success of the continuity-of-expenditure model may also reflect a preference for the individualist approach of the Common Law over the sharing norm derived from the Civil Law tradition. ${ }^{148}$ The model's methodology, like the Common Law rules, implicitly assumes that a parent's income belongs to the individual rather than the family unit. ${ }^{149}$ Viewed from this perspective, child support represents a taking of resources from its owner to benefit a third party, and one would expect a rule that prefers the owner's interests. Many of the alternative child support models that were available rely on the Civil Law sharing norm now applicable to marriage. The equal outcomes model seeks to achieve equality among family members, implicitly assuming that each is equally entitled to parental income; the utilitarian approach, which attempts to inaximize the aggregate well-being of family nembers,

146. See sources cited supra note 85 .

147. See, e.g., American Law Institute, Principles of the LaW of Family Dissolution: ANalysis AND Recommendations $\S 3.05(\mathrm{~h})$ (Preliminary Draft No. 4 1993) [hereinafter Principles of The LAW of FAmily Dissolution] ("to require... [the] noncustodial parent, in the guise of child support, [to] assume responsibility for the custodial parent... [is] culturally unacceptable"); Carol S. Bruch, Problems Inherent in Designing Child Support Guidelines, in EsSENTIALS OF CHILD SU PPORT, supra note 22, at 48 ("[S]ome policy makers . . . find the possibility of what they term 'hidden alimony' onerous enough to justify abandoning efforts to protect fully the child's standard of living."); Bassi \& Bamow, supra note 21, at 495 n.33 ("We suspect that the states reject the more generous equity concepts because the custodial parent would benefit siguificantly as well as the child.... [M]any state lcgislatures would consider such a result to be unfair in that it essentially provides the custodial parent with the equivalent of alimony as well as child support.").

148. See supra notes $72-83$ and accompanying text.

149. For a detailed discussion of the autonomy assumption, property rhetoric, and post-divorce obligations between spouses, see Milton C. Regan, Jr., Spouses and Strangers: Divorce Obligations and Property Rhetoric, 82 GEo. L.J. 2303 (1994). 
similarly assumes that no family member has a stronger claim to family income than does any other.

Evidence of a preference for the Common Law approach can be found in the so-called "self-support reserve" feature of many guidelines, which establishes an income level (typically the federal poverty level for a one-person household) below which the guideline values do not apply. ${ }^{150}$ The self-support reserve has no counterpart in traditional child support law; indeed, empirical research has shown that child support awards under traditional standards were regressive, with low-income parents typically paying greater proportions of their incomes in child support than high-income parents. ${ }^{151}$ It is not even consistent with a continuity-of-expenditure methodology; poor parents in intact families share income with their children just as do wealthier parents. The prevalence of this feature thus suggests a tendency to view parental income as parental entitlement.

The elevation of individualist over sharing goals may not, however, reflect a conscious choice of values. The Massachusetts state child support commission, for example, declared its preference for incomeequalization "as the method that best addressed the [problem of] disparity of living standards," rejecting this approach simply because of the fear that it "would provide a disincentive for both parents work."152 The evidence also suggests that many policy makers were poorly informed about the goals and capabilities of the continuity-ofexpenditure approach. A memorandum explaining New York's continuity-of-expenditure type guideline, for example, describes the primary purpose of child support as "the maintenance of the child's

150. Both the income shares and Melson formulae include a self-support reserve for the obligor. Almost no guidelines provide a support reserve for the custodial parent. See Dodson \& ENTMACHER, supra note 14, at 49-53; Williams, Guidelines, supra note 101, at 305 tbl.4. The English and Australian child support formulae also provide a self-support reserve for the support obligor. See Oldham, supra note 11 , at 713 .

151. See Lenore J. Weitzman, The Divorce Revolution: The Unexpected Social and ECONOMIC CONSEQUENCES FOR WOMEN AND CHILDREN IN AMERICA 262-69 (1985) (reporting regressive child support awards in California divorce sample); Garrison, supra note 79, at 718 tbl.53 (reporting siguificant negative relationship between percentage of obligor income awarded in coinbined child support and alimony and obligor's incoine in New York divorce sample); James B. McLindon, Separate But Unequal: The Economic Disaster of Divorce for Women and Children, 21 FAM. L.Q. 351, 371-72 (1987) (reporting regressive child support awards in Connecticut divorce sample).

152. Marilyn R. Smith \& Jon Laramore, Massachusetts' Child Support Guidelines: A Model for Development, in Essentials of CHILd SupPORT, supra note 22, at 267, 273. See also Karen Czapanskiy, Foreward, in Essentials of Chlld SupPort, supra note 22, at 5, 6 (noting that participants at national child support conference concluded that "the prinary goal of child support is to serve the best interests of the child" and that "[m]any conferees agreed that the best method [of serving the child's interests] is to seek to equalize the standards of living of the households of the supported child's parents"). 
standard of living"- a goal, as we have seen, that this guideline type could not possibly meet. ${ }^{153}$

In short, we can be confident that the continuity-of-expenditure approach was doomed to failure from the start and that its selection reflected the not uncommon legislative desire for a no-cost, pain-free solution. But we cannot be sure that its selection was the product of careful reflection on the fundamental issues of justice that underlie the selection of a child support guideline model.

There are two different approaches one might employ in resolving these underlying issues of justice. One method treats child support policy as a question of distributive justice, focusing on the determination of which child support principles are most fair to the parties involved. Another is the familiar approach of policy science and political debate, that proceeds by articulating and critiquing goals, assumptions, expected outcomes, and implementational problems. These methods are not, of course, mutually exclusive. On many issues of public concern-taxation, affirmative action, welfare policy-we routinely employ both types of analysis. This dual approach is the one I will utilize here. The next section analyzes child support policy as a question of distributive justice; the section that follows utilizes a policy science approach.

III

Child Support as Distributive Justice: Issues and Theories

\section{A. The Family and Justice}

Plato recommended its abolition. ${ }^{154}$ Cicero extolled it as the seedbed of the state. ${ }^{155}$ Rousseau recommended it as the first, and foremost, source of moral education. ${ }^{156}$ From ancient times to modern, the nuclear family has been recognized as a basic, powerful, and potentially disruptive element of civil society. Combining hierarchy with unity and inequality with altruistic self-denial, family relationships both shape and mirror the society in which they are set.

153. Governor's Approval Memorandum: Child Support Standards Act, (1989), reprinted in New York State Legislative ANnual 1989, at 250. See also Principles of thi LAW OF FAMILY Dissolution, supra note 147, at $\$ \S 3.03(1), 3.05$ (describing "most important" goal of child support as "ensur[ing] that the child share ... equitably in the incomes of both parents" and adopting income shares guideline methodology).

154. See The Republic of Plato 155-68 (Francis M. Cornford ed. \& trans., Oxford Univ. Press 1955) (advocating abolition of private homes and families for guardian class).

155. See Cicero on MORAL Obligation 58 (John Higginbotham trans., Univ. of Calif. Press 1967).

156. See Jean-Jacques Rousseau, Emile 12-20 (William H. Payne ed. \& trans., D. Appleton and Co. 1898). 
Because of its primacy, political philosophers have written extensively about the parent-child relationship. ${ }^{157}$ At least since the Enlightenment, they have tended to assume that parents owe to their children an obligation of care, protection, and education. ${ }^{158}$ But agreement on the existence of parental obligation has not produced a uniform theory (or even an array of competing accounts) of either the extent of parental obligation or its relationship to marital and community obligations. ${ }^{159}$

One explanation for this theoretical gap can be found in the tendency to assume that family relationships are governed by altruism rather than by the constraints of formal justice. ${ }^{160}$ Although this tendency has abated in contemporary discussions of marriage ${ }^{161}$ it is still dominant in discussions of the parent-child tie. ${ }^{162}$ The large conteinporary literature on issues of intergenerational justice, for example, admits the possibility of resource conflict between the young and old as generational groups, but almost invariably assumes parental altruism within the family. ${ }^{163}$ Indeed, the probability of a parent's partiality toward his or her own offspring is often described as a major

157. See Blustein, supra note 24, at 22-98 (summarizing the literature); Ross, supra note 24, at 124-35 (same).

158. See Blustein, supra note 24, at 63-90; David ARChard, Children: Rights AND Childhood 8 (1993).

159. For summaries and analyses of some main themes, see BLUSTEIN, supra note 24, at 99-138 and Ross, supra note 24, at 124-35.

160. See, e g., Joh N LOCKe, Two Treatises of Government, 181, 309, 312 (Peter Laslett ed., Cambridge Univ. Press 1988) (1690); The Republic of Plato, supra note 154, at 165-66.

161. See, e.g., OkIN, supra note 27, at 134-69; Michaed Walzer, Spheres of Justice: A Defense of PluRalism and EQUaltTy 227-42 (1983); Onora O'Neill, Justice, Gender, and International Boundaries, in THE QUALITY of LIFE 303 (Martha Nussbaum \& Amartya Sen eds., 1993).

162. See, e.g., Charles Fried, Right and Wrong 155 (1978) (observing that when a child is born, the parents' sense of autonomy is enlarged to include the child, so that "use of autonomy is the model for the deepest form of altruism"); FRIEDRICH A. HAYEK, The CONSTITUTION OF LIBERTY 91 (1960) (arguing that in certain circumstances, justice requires making use of "the natural partiality of parents for their children"); ROBERT NOZICK, ANARCHY, STATE, AND UTOP1A 167 (1974) ("[I]t is not appropriate to enforce across the wider society the relationships of love and care appropriate within a family ...."); JOHN RAWLS, A THEORY OF JUSTICE 292 (1971) [hereinafter RAWLS, THEORY OF JUSTICE] (describing assumption of "ties of sentiment" between generations); MICHAEL J. SANDEL, Liberalism AND THE Limits of Justice 33 (1982) (describing "the more or less ideal family situation, where relations are governed in large part by spontaneous affection" and where an appeal to justice "is preempted by a spirit of generosity"); Richard A. Epstein, Justice Across the Generations, in Justice BEtweEn Age Groups and Generations 89 (Peter Laslett \& James S. Fishkin eds., 1993) ("Individuals ... have heavily interdependent utility functions with their offspring. The most powerful source of this interdependence ... is genetic connection, which induces parents to take into account the utility of their children (and the reverse as well) in making decisions about present and future consumption") (footnote omitted).

163. For an introduction to the literature, see the various essays collected in JusTice ACRoss Generations: What Does it Mean? (Lee M. Cohen ed., 1993); Justice Between Age Groups and Generations, supra note 162; Obligations to Future Generations (R.I. Sikora \& Brian Barry eds., 1978). 
impediment to the achievement of equality within an age cohort and between successive generations. ${ }^{164}$

Contemporary philosophy offers little more on the extent and nature of parental obligation than do the classical theorists. Even those whose primary focus is children's rights have failed to answer-or even ask - the question of how much a parent owes to his child, to the child's other parent, and to society. ${ }^{165}$ In constructing child support principles, we cannot rely on an established account, or even choose from among competing accounts, of parental obligation.

\section{B. Child Support as a Problem of Distributive Justice}

While we lack an established ethic of parental obligation, we have a rich philosophical literature on distributive justice that might guide the development of child support principles. The problem of child support is, after all, a question of fair allocation: a finite resource, family income, must be divided between two households, each of which is headed by a parent and at least one of which includes a child (or children).

The distributive problem posed by child support combines features of what Jon Elster has aptly described as global and local justice. ${ }^{166}$ Global justice theories have as their main object the overall design of society, while local theories concern the allocation of a particular good or burden-organs for transplantation, for example-in a specific context involving imbalance between supply and demand. ${ }^{167}$ Global theories do not necessarily offer clear answers to problems of local justice; thus some global theorists have specifically disclaimed the applicability of a global design to local problems. ${ }^{168}$

164. See, e.g., Bruce A. ACKERMAN, Social JUSTICE IN THE Liberal State 201-27 (1980); JAMES S. Fishinin, Justice, Equal Opportunity, AND the FAMILY (1983); James S. Fishkin, The Limits of Intergenerational Justice, in JUSTICE BETWEen AGE Groups AND Generations, supra note 162 , at $62,73-78$.

165. The central concern of children's rights theorists has been the extent of children's autonomy as decision makers. As a result, children's substantive rights as members of a family or community have received short shrift. For representative examples of the children's rights literature, see William anken \& Hugh lafollette, Whose Child? Children's Rights, Parental Authority, AND StATE POWER (1980); ARCHARD, supra note 158; Richard Farson, BIRTHRIGHTS (1974).

166. JoN Elster, Local Justice: How Institutions Allocate SCARCE Goods and Necessary Burdens (1992); Jon Elster, Local Justice and Interpersonal Comparisons, in INTERPERSONAL COMPARISONS OF WELL-BEING, supra note 135, at 99.

167. Elster's examples include, in addition to that of organ allocation, the decision about whom to induct into military service, and the choice of workers to lay off in a recession. See ELSTER, supra note 166 , at 1 .

168. See, e.g., RAwLs, TheORY OF JUSTICE, supra note 162, at 8 (noting that "[t]here is no reason to suppose ahead of time that the principles satisfactory for the basic structure [of socicty] hold for all cases"). 
Child support, at first glance, poses only local issues: The problem arises in a single context involving parent(s) and child(ren) who live apart. But the good to be allocated, money income, is the family's most basic resource. Its distribution will largely determine the coinmodities, opportunities, and status each family member can attain. The problem of income allocation within the "little commonwealth" of the (divided) family ${ }^{169}$ thus closely reseinbles, on a sinaller scale, the distribution of primary goods with which global theories of distributive justice are concerned.

The distribution of power and resources within the family will both mirror and shape that of the larger coinmonwealth in which it is situated; "[t]he family ... reproduces the structures of kinship in the larger world [and may, for example] ... impose[] what we currently call 'sex roles' upon a range of activities to which sex is entirely irrelevant." "170 It is no accident that in societies with a tradition of male supremacy, families typically discriminate against their fenale members, or that hierarchical societies tend to produce hierarchical families. ${ }^{171}$ The distribution of familial power and resources will play a vital role in determining the status and opportunities of family members within the larger commonwealth. If, for example, the family's male children obtain all its educational resources and the female children none, the children's prospects outside the family will vary dramatically. Although adult family members will not be immune from the effects of such discrimination, the most powerful effect will be on children.

The family also serves as one of society's primary sources of moral education. It is in the family that we first encounter issues relating to the allocation of goods and responsibilities, of power, and of justice. It is here that we first learn to "put ourselves into another's place and find out what we would do in his position."172

Because of the primacy of the family, as a determinant of societal structure as well as the individual opportunities and values of family members, global theories of distributive justice would seem particularly appropriate for determining the allocation of family resources. Indeed, the interdependence of the family and larger commonwealth is a major source of traditional philosophical interest in the family.

169. See LoCKE, supra note 160 , at 323.

170. WALZER, supra note 161 , at 240 .

171. See, e.g., Barbara Harriss, Intrafamily Distribution of Hunger in South Asia, in 1 THE Political Economy of Hunger 351 (Jean Dreze \& Amartya Sen eds., 1991) (study of food allocation in primitive South Asian society); Hanna Papanek, To Each Less than She Needs, From Each More than She Can Do: Allocations, Entitlements and Value, in Persistent INequalrmies: Women AND World Development 162 (Irene Tinker ed., 1990) (study of women's survival in South Asia).

172. RAWLS, THEORY OF JUSTICE, supra note 162 , at 469. 


\section{Three Types of Distributive Justice Theories}

Contemporary philosophy offers several global theories of distributive justice that might guide the development of child support principles. The rule-making authority might opt for a division based on either a contractarian, consequentialist, or libertarian account of distributive justice; it could also rely on an intuitional approach, such as communitarianism or feminism, that combines features drawn from these various approaches or provides a distimctive emphasis. ${ }^{173}$

\section{Consequentialist Child Support Principles: Utility and Equality}

The two most prominent consequentialist theories of distributive justice today are utilitarianism and egalitarianism.

\section{a. Utilitarian Child Support}

Utilitarian theories vary in their details, but uniformly claim that resources should be distributed in a way that will maximize the good, or utility, that can be achieved. Classical utilitarianism, developed by John Stuart Mill and Jeremy Bentham, described individual happiness as the ultimate good, ${ }^{174}$ modern utilitarians have variously championed one or another notion of welfare or well-being. ${ }^{175}$

The problem with using welfare maximization as the basis of a child support rule is that we lack reliable, uncontroversial means of making interpersonal welfare comparisons, or even of measuring the relationship between an individual's income and his own welfare. These

173. Feminism and communitarianism are probably the most prominent intuitional approaches today; both are increasingly represented in philosophical and public discourse. While they offer distinctive perspectives, they share an emphasis on the variability of justice. See WALzER, supra note 161 , at 6 (arguing "that the principles of [distributive] justice are themselves pluralistic in form; that different social goods ought to be distributed for different reasons, in accordance with different procedures, by different agents; and that all these differences derive from ... historical and cultural particularism"); Nel Noddings, Caring: A Feminine Approach to Ethics and Moral EDUCATION 5 (1984) (rejecting "principles and fules as the major guide to ethical behavior [along with] ... the notion of universalizability.... Since so much depends on the subjective experience of those involved in ethical encounters, conditions are rarely 'sufficiently similar' for me to declare that you must do what 1 must do.") As a result of this emphasis on particularism, as well as the wide variety of views encompassed within eacli perspective, I have treated their probable approaches to child support policy only briefly in notes 204 and 205.

174. "Actions are right ...," Mill declared, "as they tend to promote happiness; wrong as they tend to produce the reverse of happiness." John StUART MiLl, Utilitarianism (Oskar Piest ed., Bobbs-Merril Educ. Pub. 1957) (1863). For a collection of readings illustrating the historical development of the utility concept, see Alfred N. PAge, Utility TheORY: A BOOK OF READINGS (1968).

175. See, e.g., Richard B. BRANDT, A THEORY OF THE GOOD AND THE RIGHT 214-23 (1979); James Griffin, Well-Being: Its Meaning, Measurement, and Moral Importance (1986). See also Daniel M. Hausman \& Michael S. McPherson, Taking Ethics Seriously: Economics and Contemporary Moral Philosophy, 31 J. ECON. LITERATURE 671, 689-93 (1993) (summarizing recent developments in utility theory). 
difficulties have led some experts to conclude that utilitarianism is incapable of providing a determinate resource allocation standard. ${ }^{176}$ Others have argued that, given the lack of a precise individual or interpersonal income-to-welfare metric, it makes sense to assume that individual income-to-welfare curves are equal (each individual derives the same level of well-being from the same amount of income) and that the marginal utility of money declines at a constant rate (the more dollars you have, the less each additional dollar is worth to you). ${ }^{177}$ If one uses these simplifying assumptions, a utilitarian approach yields an equal income distribution. ${ }^{178}$

A utilitarian child support formula would, of necessity, rely on these simplifying assumptions. To take account of economies of scale affecting the income-to-welfare curves of individual family members, it would also be necessary to employ a household equivalence scale. ${ }^{179}$ The resulting rule would favor the household with the larger number of family members who can derive benefit from its income, ${ }^{180}$ yielding a formula that sets the child support value at the point where the noncustodial household's welfare loss from the next dollar of income exactly equals the custodial household's welfare gain. Economist David Betson has calculated one such welfare-maximization formula; for a one-child family, it produces a ratio of pre- to post-divorce scaled surplus income of .82 for the custodial household and .59 for the noncustodial household. ${ }^{181}$

Because the utilitarian values each family member's welfare equally, the welfare-maximization formula would not include either a self-support reserve for the support obligor or a surtax designed to prevent the child's welfare dependence and/or poverty. ${ }^{182}$ But, because the utilitarian is concerned with consequences, the formula would take

176. See, e.g., John Broome, Utilitarian Metaphysics?, in INTERPERSONAL COMPARISONS of Well-Being, supra note 135, at 70; John A. Weymark, A Reconsideration of the Harsanyi-Sen Debate on Utilitarianism, in INTERPERSONAl COMPARISONS OF WELl-Be1NG, supra note 135, at 255.

177. See, e.g., Jonathan Baron, Heuristics and Biases in Equity Judgements, in Psychological Perspectives oN JUstice, supra note 35, at 109, 114-17 (describing utilitarian applications of principle of declining marginal utility to allocation of goods). While the declining marginal utility of money principle is undeniably valid in many cases (i.e., $\$ 100$ is "worth" more to the beggar than the billionaire), economists do not all agree that the marginal utility of money invariably declines, particularly for small changes in income. The marginal utility assumption is nonetheless prominent in the public finance and social welfare literature. See Betson, supra note 21, at 9 n.14.

178. See, e.g., BRANDT, supra note 175, at 312-16; R.M. HARE, Moral Thinking: ITs Levels, METhOD, AND PoINT 165-66 (1981).

179. See supra notes 135-141 and accompanying text (explaining function of household equivalence scales).

180. See, e.g., Betson, supra note 21, at 9-10.

181. Id. at 9 n.16.

182. One could make a utilitarian case for preferring the interests of clildren to those of parents, given the greater potential of a child-related investment to enhance productivity and well-being (botli for the child and society at large) over the long run. 
account of all factors that could be reliably predicted to enhance aggregate family well-being. For example, it would sanction a current income reduction, such as that resulting from an educational investment or career shift, which would likely produce a large gain in future income. It would also take account of work (dis)incentives. ${ }^{183}$ The work incentives problem derives from the fact that, if each parent stands to lose a large portion of the benefit from new income-a result that the pure welfare-maximization formula outlined above logically requireseach parent's incentive to produce more mcome is markedly reduced. The pure formula would thus require inodification to create the work incentives needed to maximize aggregate family income.

A utilitarian approach would also sanction modifications of the basic support formula that would serve to maximize social, rather than familial, welfare. For example, if the rulemaking authority determined that parental investments in children's education would produce a large social welfare gain, it might sanction either a support surcharge or a reduction $\dot{m}$ current support payments in order to finance such an investment.

In the end, a utilitarian support formula would look much like the equal outcomes approach, except that it would permit income retention by either parent that would ultimately increase aggregate family income or social welfare..$^{184}$

\section{b. Egalitarian Child Support}

"All hold that justice is some kind of equality," claimed Aristotle, ${ }^{185}$ and many contemporary distributive justice theorists have agreed. As a principle of global justice, contemporary egalitarians have argued that the appropriate goal is ensuring tolerably equal life chances; to meet this goal, they have urged equality of basic resources, opportunity, or capability. ${ }^{186}$ Using this approach, an egalitarian child

183. A number of commentators have rejected the equal outcomes approach because of its potential to create significant work disincentives. See, e.g., Principles of THE LAW of FAMiLY Dissolution, supra note 147, at $\S 3.05(\mathrm{~h}$ ) (rejecting equal outcomes approach to child support based on "substantial work disincentive for the custodial parent"); Barbara Bergmann, Setting Appropriate Levels of Child-Support Payments, in The Parental Child-Support Obligation, supra note 84, at 116 (rejecting "income-shariug formulas [because they] embody no presumption that the custodial mother will take paid work"); Smith \& Laramore, supra note 152, at 273 (choosing not to adopt an "income-equalization approach" because "it would provide a disincentive for both parcnts to work").

184. See BRANDT, supra note 175, at 310-22 (outlining utilitarian income distribution plan and arguing that it would require equal after-tax incomes except for "(a) supplements to meet spccial needs, (b) supplements recompensing services to the extent needed to provide desirable [work] incentive and allocate resources efficiently and (c) variations to achieve other socially desirable ends such as population control").

185. ARIstotle, Politics 1282 b18, quoted in Eric RakowsKi, EQUal Justice 1 (1991).

186. See RAKOWSKI, supra note 185, at 19, 73 (favoring equality based on receipt of "equally valuable opportunities and unowned resources"); SEN, supra note 139, (favoring equality of 
support principle would aim at ensuring relatively equal income-based opportunities for each family member.

There are two problems with applying this approach. First, while a focus on opportunities naturally lends itself to comparisons between agemates who are competing for the same resource pie at the same developinental stage, this approach is far more difficult to apply across generations. ${ }^{187}$ Individuals in different generations will not necessarily enjoy access to the same level of resources at a particular developmental point or across their respective life spans; nor, in competing with each other for social resources, will they be able to utilize them to obtain the same advantages. ${ }^{188}$ Given these problems, some contemporary egalitarians have argued that intergenerational comparisons should be made on a "whole lives" basis. ${ }^{189}$ Others claim that whole lives comparisons ignore important inequalities between individuals and that a "time-slice" or other point of reference is additionally required. ${ }^{190}$ Thus, while we can be confident that an egalitarian child support fornula would demand equal opportunity for all children within one

capability); WALzER, supra note 161, at 20 (favoring "complex equality" that produces an openended distributive principle requiring that "[n]o social good $\mathrm{x}$ should be distributed to men and women who possess some other good y merely because they possess $y$ and without regard to the meaning of x"); Richard J. Arneson, Equality and Equal Opportunity for Welfare, 56 PHIL. STud. 77 (1989) (favoring equality of opportunity for welfare); G.A. Cohen, On the Currency of Egalitarian Justice, 99 ETHIcs 906-33 (1989) (favoring equal access to advantage); Ronald Dworkin, What Is Equality? Part 2: Equality of Resources, 10 PHIL. \& PUB. AFr. 283 (1981) (favoring equality of resources); Amartya K. Sen, The Standard of Living: Lecture II, Lives and Capabilities, in THE STANDARD OF Living 20, 36-38 (Geoffrey Hawthorn ed., 1987) (urging consideration of a capability standard). For useful comparisons of the various formulations, see G.A. Cohen, Equality of What? On Welfare, Goods, and Capabilities, in THE QuALrTY of LIFE, supra note 161, at 9; Amartya Sen, Capabilities and Well-Being, in THE QUALITY OF LIFE, supra note 161, at 30.

187. See Norman Daniels, The Prudential Lifespan Account of Justice Across Generations, in Justice Across Generations: What Does it Mean?, supra note 163, at 197, 199 ("[I]f we treat the young one way as a matter of policy and the old another, and we do so over their whole lives, then we treat all persons the same way. No inequality between persons is produced since each person is treated both ways in the course of a complete life. Thus the banal fact that we age means age is different from race or sex for purposes of distributive justice.").

188. For example, we would not typically think that inequality between the young and old in access to education is a meaningful form of inequality.

189. See, e.g., Thomas Nagel, EQuality and Partialtry 69 (1991); Dworkin, supra note 186, at 304-05. Rawls also appears to espouse the "whole lives" view. See RAwLS, THEORY of JUSTICE, supra note 162 , at 78, $92-95$.

190. See Norman Daniels, Am I My Parents' Kegper? An Essay on Justice Between THE YOUNG AND THE OLD (1988) (arguing in favor of "prudential life span" account of generational equity in which intergenerational comparisons are based on a prudential distribution of lifetime resources over the different temporal stages of a single life); Daniels, supra note 187 (same). See also Derex Parfit, Reasons and Persons 339-45 (1984) (arguing against whole lives perspective based on its assumption that hardship during one phase of life is compensable in another); Dennis McKerlie, Justice Between Neighboring Generations, in Justice ACross Generations: What DoEs IT MEan?, supra note 163, at 215, 225 ("There are constraints on just distribution between age groups that are independent of, and can compete with, the concern for fairness in terms of complete lives."). 
family, we cannot be certain how it would assess the claims of a noncustodial parent and his children. An egalitarian formula might require poor parents to pay more support than others in order to avoid an adverse impact on the child's future life prospects; ${ }^{191}$ or the provision of minimum support might be viewed as a community responsibility in cases where family income is insufficient to provide all family members with mimimally adequate support.

A second problem lies in the measurement of equality. While contemporary egalitarians agree that the appropriate focus is on the achievement of relatively equal life chances, there is no more consensus on how such prospects should be measured, or on the relationship between those prospects and income distribution, than there is among utilitarians on how to make imterpersonal welfare comparisons. ${ }^{192}$ While equalization of the dollar incomes of each family member would not necessarily be required to meet egalitarian concerns, it would be necessary for the legislature to choose one or another egalitarian metric. Here there are any number of possibilities. A narrow approach to equal opportunity might produce a child support rule aimed at ensuring that each family member's basic needs are met. ${ }^{193}$ A broader approach to equal opportunity would, once again, produce something akin to the equal outcomes model. ${ }^{194}$

\section{A Contractarian Child Support Principle}

A contractarian views society as a cooperative venture for mutual advantage among self-interested persons. A just distribution of resources is that distribution to which those self-interested individuals would freely agree. ${ }^{195}$ While the notion of a social contract dates back to

191. This approach would be easier to justify within an egalitarian framework if the parent had enjoyed minimally adequate support as a child.

192. See, e.g., Amartya Sen, Equality of What?, in Chorce, Welfarg and Mzasurement 353 (1982); G.A. Cohen, Equality of What? On Welfare, Goods, and Capabilities, in THe QualrTY of LIFE, supra note 161 , at 9.

193. See, e.g., RAKowSKI, supra note 185, at 154-56, 159 (arguing that parents have an obligation to provide their children with a "basic bundle of resources," but that "gifts from parents to children [in excess of the basic bundle] ought to be regarded largely as instances of good brute luck from the children's perspective and treated accordingly"). For a detailed discussion of the needs concept and its relationship to egalitarian justice, see DAvid BraYBrooke, MeEting NeEds 32-75, 138-50 (1987).

194. For a detailed exposition of the concept of the standard of living and its relationship to social justice, sce The Standard of Living, supra note 186. For examples of altemative means of measuring standard of living, see Robert Erikson, Descriptions of Inequality: The Swedish Approach to Welfare Research, in THE QUALITY OF LIFE, supra note 161, at 67 (describing Swedish "level of living" scale and survey); B.M.S. van Praag, The Relativity of the Welfare Concept, in THE QUALITY of LIFE, supra note 161, at 362, 367-68 (describing "income evaluation questionnaire" method of evaluating individual welfare).

195. See, e.g., RAWLs, THeORY of JUstice, supra note 162, at 13 (discussing the choice of first principles). 
Hobbes, Locke, and Rousseau, ${ }^{196}$ the most influential contemporary contractarian is John Rawls. Rawls's distinctive contribution to the classical social contract tradition was to posit a hypothetical "original position of eqnality" from which the contractors would choose the principles by which society will be ordered. Rawls allows the contractors knowledge of "whatever general facts [might] affect the[ir] choice of ... principles," including politics, economics, social organization, and human psychology, ${ }^{197}$ but denies them knowledge of their own individual abilities and status. ${ }^{198} \mathrm{He}$ asserts that an agreement so made would be jnst because of its basis in an impartial process that gives each contractor equal knowledge and power. He also asserts that, under these constrained circumstances, the contractors would opt for what he terms a "maximin" approach to the distribution of social and economic inequalities; under the maximin approach, inequalities are permitted only to the extent that they benefit the least advantaged group. ${ }^{199}$

Applied to the problem of child support, ${ }^{200}$ the maximin approach would yield something like the equal outcomes model with income

196. See, e.g., J.W. Gough, The Social Contract: A Critical Study of its DEvelopmENT (1936) (surveying the historical development of the social contract tradition).

197. RAWLS, THEORY OF JUSTICE, supra note 162, at 137.

198. See ID. at 12 ("Among the essential features of this situation is that no one knows his place in society, his class position or social status, nor does any one know his fortune in the distribution of natural assets and abilities, his intelligence, strength, and the like.... The principles of justice are chosen behind a veil of ignorance."). See also id. at 136-50 (offering a detailed account of the original position).

199. See id. at 14-15, 151-52. In its fullest form Rawls states the principle as requiring that "[s]ocial and economic inequalities are to be arranged so that they are both: (a) to the greatest benefit of the least advantaged, consistent with the just savings principle, and (b) attached to offices and positions open to all under conditions of fair equality of opportunity." Id. at 302.

200. Rawls himself specifically disclaims the applicability of the maxim in principle to issues other than the basic structure of society and likely would disavow its use as a measure of fair child support. See RaWLS, Political Liberalism, supra note 31, at 261; RaWls, Theory of Justice, supra note 162, at 8-9. In A Theory of Justice, Rawls avoids all problems of intrafamilial justice by presuming that persons in the original position represent family lines, with ties of sentiment between successive generations. ID. at 128-29, 146. Susan Okin has ably criticized Rawls's failure to take account of gender inequalities within the family. See OKN, supra note 27 . See also Linda R. Hirshman, Is the Original Position Inherently Male-Superior?, 94 Colum. L. REv. 1860 (1994); Linda C. McClain, “Atomistic Man" Revisited: Liberalism, Connection, and Feminist Jurisprudence, 65 S. CAL. L. REv. 1171 (1992). My own adaptation of Rawls's methodology draws on Okin's revision of Rawls and extends it to the parent-child relationship.

In recent years, Rawls himself has expressed the belief that his theory is applicable to "problems of gender and the family" (RAwLS, Political Liberalism, supra note 31, at xxix), and has now offered an account of low the theory does apply. See Rawls, Public Reason, supra note 32 . He states that "[t]he family is part of the basic structure since one of its main rules is to be the basis of the orderly production and reproduction of society and its culture from one generation to the next," (id. at 787), and notes that, although "[t] he principles of political justice are . . not to apply directly to the internal life of the ... family, ... they do impose essential constraints on the family as an institution." Id. at 789. Thus, while "we are not required to treat our children in accordance with political principles[,] ... the principles of justice impose constraints on the family on behalf of children who as society's future citizens have basic rights as such." Id. at 790-91. These constraints appear to apply 
maximization incentives. Rawls's conclusion that rational contractors would select a maximin approach is not uncontroversial; some commentators have argued that rational contractors would select a different distributive principle-a utilitarian approach, or utilitarianism with a floor constraint. ${ }^{201}$ But this controversy appears to be largely insignificant for purposes of child support policy. As utilitarianism also yields a child support policy aimed at equal outcomes with income maximization incentives, we would obtain pretty much the same result under either approach.

\section{Contractarian and Consequentialist Child Support: Similarities and Differences}

Differences between the contractarian and consequentialist models emerge from variation in the range of goals that might justify modification of the basic equal outcomes model. While the utilitarian legislator would focus on welfare maximization, the Rawlsian legislator would focus on enhancing the opportunities of those with the least opportunity. ${ }^{202}$ Thus the Rawlsian rulemaking authority might modify the equal outcomes support value downward for high-income obligors

to economic inequalities occasioned by family dissolution, as Rawls notes that "[i]t seems intolerably unjust that a husband may depart the family taking his earning power with him and leaving his wifc and chidlren far less advantaged than before.... A society that permits this does not care about women, much less about their equality, or even about their children, who are its future." Id. at 794. But issues of justice within the family, aecording to Rawls, are not necessarily to be decided on the basis of those principles applicable to society as a whole: "As citizens we have reasons to impose the constraints specified by the political principles of justice on associations; while as members of associations we have reaons for limiting those constraints so that they leave room for a free and flourishing internal life appropriate to the association in question. Here again wc see the need for the division of labor between different kinds of principles. We wouldn't want political princples of justice-including principles of distributive justice-to apply directly to the internal life of the family." Id at 790 .

201. See John C. Harsanyi, Can the Maximin Principle Serve as a Basis for Morality? A Critique of John Rawls's Theory, 69 AM. PoL. ScI. Rev. 594, 600 (1975) (coneluding that contractors would opt for the principle of average utility); Roger E. Howe \& John E. Roemer, Rawlsian Justice as the Core of A Game, 71 AM. ECON. REv. 880 (1981) (concluding that contractors exhibiting moderate degree of risk aversion would opt for unconstrained income maximization with a floor constraint). See also David Gauthier, Morals By Agreement 14, 205, 235, 264-65 (1986) (arguing that rational contractor would opt for the Lockean proviso (i.e., the principle that one must not bctter one's own situation through interaction that worsens the situation of another), the market, and a principle of "minimax relativc concession," requiring that the greatest bargaining concession, measured as a proportion of the difference between the least the conceder might accept in place of no agreeement and the most he might receive in place of being excluded by others from agreement, be as small as possible). Gauthier does not explain how, if at all, the minimax relative concession principle applies to the distribution of social resources. See David Braybrooke, Social Contract Theory's Fanciest Flight, 97 ETHICs 750, 758-59 (1987) (arguing that Gauthier's theory cannot be used for real world policy-making.)

202. See RAWLS, TheORY OF JUSTICE, supra note 162, at 302-03. 
if support at that level unduly advantaged their children as compared to children with the least opportunity. ${ }^{203}$

But the most notable fact to emerge from a comparison of the contractarian and consequentialist approaches to child support policy is the uniformity of their results. Whether we apply a utilitarian, egalitarian, or contractarian perspective, we obtain a sharing norm as a governing principle and some variant of the equal outcomes modelmost probably with an income-maximization feature, perhaps with floor constraint, perhaps with one or another modification to ineet important social goals-as a decision-making rule. While the exact contours of a feminist ${ }^{204}$ or a communitarian ${ }^{205}$ support policy are more difficult to

203. See id. at 277-78 (noting that purpose of taxation should be "gradually and continually to correct the distribution of wealth and to prevent concentrations of power detrimental to the fair value of political liberty and fair equality of opportunity" and maintaining that "inheritance is permissible provided that the resulting inequalities are to the advantage of the least fortunate and compatible with liberty and fair equality of opportunity").

204. Feminist thinkers have tended to emphasize norms based on reciprocity and caring, with care "held to encompass a range of characteristic dispositions, such as concern for the other not out of duty or obligation but out of feeling or sympathy; attention or attentiveness; sensitivity to the needs of others, and more strongly, taking the others' interests as equal to or more important than one's own ... and an orientation to the common interest of the family or of those who are close or related to one." Carol C. Gould, Feminism and Democratic Community Revisited, in Democratic ConmunitY: XXXV Nomos 396, 404 (John W. Chapman \& Ian Shapiro eds., 1993). They have also tended to see the maternal relation as a normative model. See, e.g., Noddings, supra note 173; Sara Ruddick, Maternal Thinking: Towards a Politics of Peace (1989); Virginia Held, Mothering Versus Contract, in Beyond SElF-INTEREST 287 (Jane J. Mansbridge ed., 1990). These various tendencies all point to a child support model that would equally weight the claims of children and other family members. But, given feminism's central concern with the way that traditional marriage and child rearing perpetuate gender inequalities, a feminist analysis might well focus on obligations between parents more than does either a contractarian or consequentialist approach. See, e.g., OKIN, supra note 27; Carbone, supra note 88.

205. While communitarian thinkers are a diverse group, they uniformly favor a deemphasis on abstract individual rights; they tend to einphasize the individual's embeddedness in various communities of interest, such as the family. For representative examples of the philosphical literature, see Alasdair Maclntyre, AfTer Virtue (2d ed. 1984); Michael J. Sandel, Liberalism AND THE LIMITS OF Justice (1982); Charles Taylor, Atomism \& What's Wrong with Negative Liberty?, in Philosophy and the Human Sciences: Philosophical Papers 187-210, 211-29 (1985); WALZER, supra note 161. Communitarians typically favor legal rules that protect communities and their values. See, e.g., Michael Sandel, Morality and the Liberal Ideal, THE NEw REPublic, May 7, 1984, at 15-17 (explaining that communitarians would be more likely than rightsbased liberals to favor rules that ban pornography when it offends a community's way of life and rules that disallow plant closings that would devastate communities). Some stress the importance of traditions related to social roles, such as parenting, as a source of ethical norms. See, e.g., MACINTYRE, supra, at 17,187, 192-93. A communitarian account of the child support obligation thus would probably stress the importance of rules emphasizing the primacy of the family as an institution over the individual "rights" of its members; this viewpoint dovetails nicely with an account of the support obligation as derived from family membership. But because communitarians are a diverse group and have not developed a clear methodological approach, it is difficult to offer a more detailed account. See Elizabeth S. Scott, Rehabilitating Liberalism in Modern Divorce Law, 1994 Utah L. REv. 687, 692-701 (1994) (sketching and critiquing the communitarian values from a liberal perspective). 
discern, both of these approaches can also be employed to generate a similar model.

The uniform results of these varied approaches derive from a common emphasis on group membership as the primary determinant of a distributional principle. ${ }^{206}$ Because of that emphasis, none of the models emphasizes obligations to the other parent or to society as a source of support principles, nor is it clear what role these obligations might play in a child support policy. ${ }^{207}$ None assumes that individuals have economic entitlements that trump the needs of the family group. And none yields principles even remotely resembling current continuity-of-expenditure guidelines.

\section{Libertarian Child Support: A Minimalist Approach}

The libertarian perspective deviates from this uniform pattern and offers a different approach to child support policy. Although the libertarian perspective owes its origins to the same Lockean tradition that produced the contractarian model, a libertarian account of distributive justice responds to a different set of questions and has evolved an entirely different set of answers. While the contractarian focuses on the process by which a distribution is determined, the libertarian looks at the means by which an individual's holdings were obtained. ${ }^{203}$ To the extent that these holdings were acquired without violation of principles of justice, the libertarian holds that retention (or

206. The Rawlsian scenario "forces each person in the original position to take the good of others into account." RAwLs, THEORY OF JUSTICE, supra note 162, at 148. The utilitarian must maximize aggregate group welfare, see supra notes 174-178, and the egalitarian must treat each member of the group equally. See supra notes 186-190.

207. None of these theories offers a direct explanation of why a parent instead of, say, the extended family or community, should shoulder the obligation to support a particular child. It is theoretically possible, working within any of these traditions, to bypass the traditional nuclear family and posit some other entity as the relevant support group. For a similar view, see Rawls, Public Reason, supra note 32, at n.60 ("no particular form of the family (monogamous, heterosexual, or otherwise) is required by a pohtical conception of justice so long as the family is arranged to fulfill the $[$ tasks [of nurturing and developing citizens with a sense of justice] effectively and doesn't run afoul of other political values."). A just society could not, of course, choose a support group arbitrarily; perforce it would turn to the group which, at that historical moment, is believed to bear primary responsibility for nurturing and developing its future citizens. See, e.g., MARGARET MEAD, Male AND Female 188-9I (1949) ("When we survey all known human societies, we find everywhere soine form of the family... [but w] hich women and which children are provided for [by which men] is entirely a matter of social arrangements ...). See also infra Part 1V.D.2 (discussing faimess of applying community principle to separated family).

208. Influential libertarian accounts of distributive justice include JAMES M. BUCHANAN, THE Limits of LiberTy: BeTweEN ANARChy aNd LeviathaN (1975), FrIedrich A. Hayek, ThB Constitution of Liberty (1960), JAN NARveson, The Libertarian ldea (1988), and Nozick, supra note 162. 
disposition as the holder sees fit) of those goods cannot violate principles of justice. ${ }^{209}$

At first glance, the libertarian viewpoint is ill-adapted to the problem of income allocation within a family unit. If (just) individual acquisition creates individnal entitlement, children would appear to have no claim against their parents whatsoever. Abandonment, under this approach, seems freely permissible.

But even the minimalist libertarian state requires its members to refrain from harming the interests of others. ${ }^{210}$ Parents in a libertarian state could not demand that other members of the community care for their children any more than they could demand that the community care for their livestock or family pet; the individual's introduction into the community of a creature needing care creates a corresponding obligation to ensure that the creature does not burden other community members. Animals can, of course, be returned to nature. The infant or young child cannot; the demands of its care thus impose obligations upon those who have brought it into the community.

The libertarian state also enforces contracts. ${ }^{211}$ The individual who agrees to perform a particular act must compensate those who rely on her promise. To the extent that one parent has relied on the support promise of the other as a condition of bearing the child, the libertarian state would enforce the agreement.

Applying these principles, a libertarian child support law would intrude minimally upon the noncustodial parent's prerogatives, but nonetheless would require support at a level which ensures that the community is not burdened with the child's care and which is consistent with promises that induced the child's birth. This approach yields uncertain results, depending on how broadly community burden and child-bearing promises are interpreted. Community burden might be restrictively equated with public assistance costs or more broadly interpreted to include the enormously expensive long-range

209. See, e.g., HAYEK, supra note 208, at 140-41; NARVESON, supra note 208, at 94-99; NozICK, supra note 162, at 151.

210. This typically results from acceptance of Locke's proviso, requiring each individual to refrain from acquisitive actions that harm others. See NARVESON, supra note 208, at 217, 239 (arguing that the libertarian agenda includes "the right that others not, in various ways, molest you" and noting need for "network of moral and possibly legal reinforcement... for virtually any market"); Nozick, supra note 162, at 175 (adopting Lockean proviso and noting that it "is meant to ensure that the situation of others is not worsened").

211. See HAYEK, supra note 208, at 141 ("The whole network of rights created by contracts is as important a part of our own protected sphere, as much the basis of our plans, as any proporty of our own ... The rules of property and contract are required to delimit the individual's private sphere wherever the resources or services needed for the pursuit of his aims are scarce and must, in consequence, be under the control of some man or another."); NARVESON, supra note 208, at 196 (noting that justice requires contract enforcement). 
consequences of childhood poverty. ${ }^{212}$ Child-bearing promises might be confined to explicit, written agreements or interpreted more expansively to include implied agreements derived from conventional behavior.

\section{Child Support Past and Present: The Legacy of Locke and its Transformation}

Although none of the four perspectives on distributive justice that I have described would produce a child support principle identical to either traditional support law or the new support guidelines, the perspective most compatible with the law on the books is undeniably the libertarian. This is the only perspective that assumes, as does past and current support law, that parents are individually entitled to their income; it is the only perspective that views child support as a taking which demands a justification; it is the only perspective that measures the child support obligation based on public expense and private contractual obligation.

The justifications implicit within traditional support law also bear more than a passing resemblance to the community and contractual obligations that provide a basis for child support within a libertarian state. The Poor Law tradition represented a minimal intrusion upon parental prerogatives that was precisely tailored to reimburse the community for care it had provided; ${ }^{213}$ the private law of child support that emerged during the nineteenth century provided a remedymeasured by past expenditure, from which the contract breaker's implied promise could be inferred-to the parent victimized by a broken marital contract. ${ }^{214}$

Traditional support law was not purely libertarian, however. It permitted a custodial parent who had herself breached the marital contract to obtain child support along with the victimized parent. This

212. Poor children are disproportionately likely to experience poor health, see Lorraine V. Klerman, The Health of Poor Children: Problems and Programs, in Childonen IN Poverty, supra note 3, at 136-57, as well as abuse, neglect, and other forms of family dysfunction. See, e.g., U.S. Dep't of Health and Human Services, Nat'l. Center on Child Abuse and Neglect, Study of National Incidence and Prevalence of Child Abuse and Neglect (1988); Joan 1. Vondra, Childhood Poverty and Child Maltreatment, in ChIld Poverty AND Public Policy 128-39 (Judith A. Chafel ed., 1993). As adults, they have significantly higher rates of divorce, early childbearing, reduced educational attainment, low occupational status, and welfare dependence. For reviews of research on the immediate and long-range consequences of childhood poverty, see ChilD Poverty aNd Public Policy, supra; Children in Poverty, supra note 3; Children in Poverty: Special Issue, 65 Child DEv. $275-715$ (1994). For discussion of the public costs associated with childhood poverty, see, for example, Haveman \& Wolfe, supra note I; NAT'L COMM'N ON Children, Beyond Rhetoric: A New American Agenda for Children and Famllies 2-13 (1991).

213. See supra notes $38-41$ and accompanying text.

214. See supra notes $47-52$ and accompanying text. 
cannot be justified on the basis of an implied promise to the child because such a promise would involve no "meeting of the minds" and could not imduce reliance.

In order to fully justify traditional support law within a libertarian framework, one must therefore assume a duty owed by the parent directly to the child. While modern libertarians have seldom addressed this issue, ${ }^{215}$ their Enlightenment forebears were firmly committed to an ethic of parental obligation. John Locke, the most important source of libertarian property concepts, rejected absolute parental authority just as he rejected monarchical authority: though a parent "may dispose of his own Possessions as he pleases, when his Children are out of danger of perishing for want," Locke held, "[t]he Nourishment and Education of their Children, is a Charge so mcumbent on Parents for their Childrens [sic] good, that nothing can absolve them from taking care of it."216 Nor did Locke view the child's claim as extending "only to a bare Subsistence but [instead] to the conveniences and comforts of Life, as far as the conditions of their Parents can afford it."217 Traditional support law is thus most easily characterized as a Lockean construct: while it is firmly committed to an individual entitlement approach to parental income, it is also firmly committed to the view that parental duty is an mviolable obligation owed directly to the child and measured by parental ability to pay. ${ }^{218}$

Current guidelimes retain much of the Lockean perspective. They presuppose a parental obligation runniug directly to the child, ${ }^{219}$ assume a parent's entitlement to his income, and base the support obligation on parental spending patterns. They depart from Locke, however, by favoring the parent's needs over those of the child. While Locke and traditional support law held that the support obligation took precedence over parental interests, guidelines providing for a self-support reserve clearly do not. Under these formulae, even the parent whose children burden the community through receipt of public assistance may owe no, or token, child support if his own income falls below the statutory

215. But see NARVESON, supra note 208, at 269-74 (refusing to condemn infanticide in societies where there is an extreme scarcity of resources, but finding that in an affluent society such as ours “[t]he public interest in our fellows' welfare is sufficient to justify requiring parents to take proper and nonabusive care of their children.") $I d$. at 274.

216. Locke, supra note 160, at 311-12. See also NARVESON, supra note 208, at 310 ("So little power does the bare act of begetting give a Man over his Issue, ... that when he quits his Care ... he loses his power over them.").

217. Id. at 207.

218. For a discussion of Locke's views on parental obligation, see A. JoHN SIMMONS, THE LOCKEAN THEORY OF RIGHTS 192-212 (1992).

219. This is perhaps most readily apparent in the cases involving conception fraud or deceit. See infra note 282 and sources cited therein. 
personal support allowance. 20 Perhaps more importantly, Locke measured the support obligation by what the parent could afford, a child-centered metric that hints at an underlying sharing norm. ${ }^{221}$ Continuity-of-expenditure guidelines, by contrast, measure support by the extra expenses induced by the birth of a child in an intact family. ${ }^{222}$ The shift is subtle, but nonetheless produces a more parent-centered metric.

It is not surprising that traditional child support law would evidence a Lockean perspective; Locke's ideas were extremely influential at the time the American republic was founded and underlie many of our social and political institutions. ${ }^{223}$ Nor is it surprising that contemporary child support law would evidence some erosion of its Lockean foundation. Changes in social and economic conditions since the Republic's founding have produced a variety of post-Lockean legal developinents-antitrust law, environmental regulation, income and estate taxation-that Locke could not have envisioned and that do not fit neatly within his world view.

What is surprising - at least at first glance-is the direction taken by contemporary support law. Given the parental responsibility rhetoric that accompanied the guidelines movement, it seems odd that its primary post-Lockean innovation would be less parental responsibility; as Locke was a founding father of the contractarian tradition as well as libertarian property entitlement concepts, it also seems odd that the new guidelines would be compatible only with a libertarian perspective. Although Locke did not explicitly extend his contractarian account of civil government to the parent-child relationship, in his view, both parental and political authority were "for the benefit of the Governed;"224 thus, children, "by the dependence they have on their Parents for Subsistence, have a Right of Inheritance to their Fathers [sic]

220. Guidelines that follow the Melson approach, as well as most income-shares guidelines, provide for a self-support reserve. See supra note 150 and accompanying text.

221. For a similar view, see Milton C. Regan, Jr., The Boundaries of Care: Constructing Community After Divorce, 31 Hous. L. REv. 425, 433 (arguing that Locke viewed "family members [as] linked by claims and responsibilities that arise through dependence rather than simply consent").

222. See supra notes 98-100, 106-109 and accompanying text.

223. See Thomas Pangle, The Spirit of Modern Republicanism: The Moral Vision of the American Founders and the Philosophy of Locke 129-275 (1988) (describing Locke's influence upon the founders of the American republic). But see Mark L. Ascher, Curtailing Inherited Wealth, 89 Mrch. L. REv. 69, 76.81 (1990) (arguing that Locke's natural rights theory of inheritance was less influential with the republic's founders than positivistic theory of inheritance derived from Blackstone). Some commentators have also noted a relationship between Locke's view of the parent-child relationship and changing child-rearing patterns that emerged in the late eighteenth

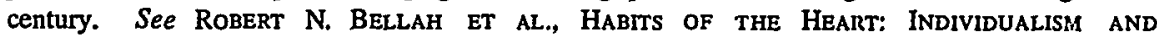
COMMTMENT IN AMERICAN LIFE 57-58 (1985).

224. LOCKE, supra note 160 , at 210 . A parent's authority over his children thus "goes along with their Nourishment and Education, to which it is inseparably annexed." Id. at 310. 
Property, as that which belongs to them for their proper good and behoof."225 This account of child support as a fiduciary obligation taking precedence over parental entitlement is notably absent both from the libertarian view and current guidelines.

The new guidelines thus transform child support law's traditional Lockean framework by placing more emphasis on parental entitlement and less on parental responsibility. Put somewhat differently, contemporary support law appears to prefer Locke, the property rights libertarian, to Locke, the contractarian.

\section{E. Current Guidelines: A Failure by Any Measure}

In evaluating current guidelines, it is important to keep in mind that they are grounded in a philosophical tradition that emphasizes property rights and individual autonomy. These aspects of the Lockean tradition clearly retain a powerful grip on the American imagination, fueling distrust of "big government" and a tendency to look to individual behavior as a reason for and solution to social probleins. Indeed, one way to understand the federal child support initiatives is as an atteinpt to explain and reverse a rising tide of children's poverty through the behavior of individual "deadbeat dads."226

The ideological roots of the child support initiatives help to explicate the anomaly of a legislative program that is framed in terms of parental responsibility but nonetheless elevates parental interests. The failure of that initiative to meet its stated goals also provides an example of how individualist rhetoric can "inhibit a broader understanding of self and a longer-term sense of interests."227

Even within a libertarian framework, however, current guidelines fall short. Libertarian child support would be set at a level that prevents welfare dependence and/or poverty; support awards-like the results of traditional child support laws-would be regressive, to the point at which work and payment disincentives dictate otherwise. ${ }^{228}$ Even the Melson

225. Id. at 210. Locke's views on children's inheritance rights have bcen variously interpreted. See, e.g., PANGLE, supra note 223, at 232-33 (comparing Grotius' theory regarding inheritance to that promulgated by Locke); SimMoNs, supra note 218, at 204-12 (noting the various interpretations of Locke's theories); J.J. Waldron, Locke's Account of Inheritance and Bequest, 19 J. HIST. PHII. 39 (1981).

226. See Michael P. Katz, The Undeserving Poor 237-38 (1989) (noting the "peculiarly American tendency to transform poverty from a product of politics and economics into a matter of individual behavior").

227. Robert N. Bellah Et al., The Good Society 141-42 (1991). See also Mary A Glendon, Rights Talk: The Impoverishment of Political Discourse 25 (1991) (arguing that "[f]rom the very beginning, the absoluteness of American property rhetoric promoted illusions and inpeded clear thinking about property rights and rights in general").

228. For a discussion of how support guidelines might be modified to take these disincentives into account, see infra notes $240-243$ and accompanying text. If the child support obligor has insufficient 
formula, the only current guideline that takes poverty prevention as its primary goal, does not meet these requirements; it provides a selfsupport reserve for the child support obligor, elevating his interests above those of the public, and fails to utilize a genuinely regressive support schedule. ${ }^{229}$ Continuity-of-expenditure guidelines fall short by a wider margin. Although some do utilize regressive schedules, none takes welfare (or poverty) prevention as a basic goal or varies the support award to take account of the child's possible welfare dependence. ${ }^{230}$

Current guidelines could be "fixed" to conform to a libertarian framework. The revised guidelines would take welfare (or poverty) prevention as their central aim and employ regressive schedules as necessary to effectuate that objective. Above the poverty line, the continuity-of-expenditure approach could be retained, as the only libertarian goal applicable at this point is the satisfaction of promises to the other parent. Current guidelines achieve results consistent with those obtained under traditional discretionary standards and thus would probably meet an implied promise test. ${ }^{231}$

Within any other distributive justice framework-utilitarian, egalitarian, contractarian-current guidelines would have to be scrapped. ${ }^{232}$ All of these nonlibertarian approaches require a sharing norm and yield some version of the equal outcomes model. The

income to avert welfare dependence and/or poverty, the support award should still be set at a level equal to public expenditure in order to provide a basis for obtaining future reimbursement.

229. See supra notes 107-109, 150 and accompanying text.

230. See supra notes $97-104$ and accompanying text.

231. See supra notes 113-116 and sources cited therein.

232. Current guidelines could, of course, be remodelled to produce results that come closer to achieving equal outcomes. The results of current guidelines vary widely. In the Women's Legal Defense Fund study, nine state guidelines produced awards that provided children with less than $60 \%$ of what would be needed to achieve a living standard equal to that of the noncustodial parent while the Connecticut, Massachusetts and District of Columbia guidelines produced awards equalling more than $85 \%$ of what would be needed. DoDson \& ENTMACHER, supra note 14 , at 22, tbl.3-D. The relative success of the Connecticut, Massachusetts and District of Columbia guidelines appears to stem primarily from the fact that they rely on estimates of child-related expenditure higher than those contained in most guidelines. See id. at 43. The Massachusetts and District of Columbia guidelines also provide a self-support reserve for the custodial parent. See id. at 54. Standards recently drafted under the auspices of the American Law Institute urge states to adopt the Massachusetts/D.C. model because it "better accomplishes the objectives of providing adequately for the child, avoiding shocking disproportion between the standards of living of the child and the nonresidential parent, and realizing the goal of faimess to the obligor when he is the lower income parent." AMERICAN LAW INSTITUTE, PRINCIPLES OF THE LAW OF FAMILY DisSOLUTION: ANALYSIS AND RECOMMENDATIONS $\S 3.04 \mathrm{cmt}$. a (Preliminary Draft No. 7, vol. I, June 9, 1997). The modifications that enable the Massachusetts/District of Columbia guidelines to produce higher support awards than other continuity -of-expenditure guidelines reduce its conceptual clarity. See PRINCIPLES of THE LaW of FamiLy Dissolution, supra, at $\$ 3.04 \mathrm{cmt}$. d(iii) (noting that the model's "basic measure of child support is not as susceptible to easy definition as are [standard continuity of expenditure guidelines and the equal outcomes model]"). 
individual eutitlenents assumption of current guidelines is so inconsistent with this approach that revision would not be possible.

The key question, of course, is which approach we want. The fact that current support law expresses an underlying libertarian perspective does not tell us whether that perspective is the one inost coinpatible with contemporary views of parental obligation. Debate about basic goals and values was extremely limited at the time current guidelines were adopted; soine legislatures appeared to be confused about the goals and limitations of the continuity-of-expenditure approach; and some policymakers explicitly preferred the policy goals of the equal outcomes approach, rejecting it solely for practical reasons. ${ }^{233}$ The triumph of a sharing approach in rules governing marriage also suggests caution before we simply assume that a libertarian approach is the right one in child support; legal rules do not always evolve smoothly and may be "out of synch" with each other or contemporary mores for a long while before change occurs. ${ }^{234}$ Within the area of family law, for example, the legal requirement that one spouse demonstrate the other's fault as a precondition to divorce was largely ignored by both courts and litigants for decades before no-fault divorce was formally instituted. ${ }^{235}$

It is not even clear that the choice between libertarian and sharing goals is an either/or proposition. Libertarian child support is derived prinarily from obligations to the coinmunity and the other parent while the sharing approach focuses on obligations arising within a family unit, based on membership in that unit. We might conclude that child support law should take account of both forms of obligation, mandating sharing within the family and poverty prevention to meet parental obligations to the coinmuuity.

It is clear that change is in order. We should aim either at a libertarian child support rule, which assumes individual parental autonomy and restricts support to an ainount which will protect society and the justifiable expectations of the custodial parent, or at a community approach, which treats parental incoine as belonging to the family unit and seeks a just distribution among that group, or at some coinbination of the two. We should not retam current guidelines, which fail by any measure.

233. See supra notes $152-153$ and accompanying text.

234. See DwORKIN, supra note 32, at 89-90 (describing patterns of legal change).

235. For descriptions of litigant and court practices, see Note, Collusive and Consensual Divorce and the New York Anomaly, 36 Colum. L. REv. 1121 (1936); Note, The Administration of Divorce: A Philadelphia Study, 101 U. PA. L. Rev. 1204 (1953). See also Max Rheinstein, Marriage STABiLITY, DivorCe, AND THE LAW 63 (1972) (concluding that "consent divorce, abhorred in the official law of all states, is an established institution of American law"). 


\section{IV \\ Autonomy or COMMUNITY: What ChILd SUPPORT MODEL DO WE WANT?}

\section{A. Developing the Models}

In order to make an informed choice between the libertarian and community support models, we need to understand their results as well as their goals. These results are not, of course, carved in stone. A libertarian, autonomy-based model might focus narrowly on welfare prevention or more broadly on poverty; a community model might seek full equality between parent and child or a more limited equality of basic resources. Each model's results will also be affected by the manner in which practical problems such as work and payment disincentives are taken into account. This section will develop two variants of each model. Model A, the "Narrow Autonomy Model," takes welfare avoidance as its primary goal; Model B, the "Broad Autonomy Model," focuses on poverty prevention; Model C, the "Limited Community Model," aims at equality of basic resources; and Model D, the "Full Community Model," seeks equality in living standards.

The implementation of each model requires choices on the means to effectuate its basic goal. For example, all of the models except A require use of a household equivalence scale to measure the comparative circumstances (or poverty) of family members. ${ }^{236}$ Model B also requires the selection of a poverty line, ${ }^{237}$ while Model $\mathrm{C}$ requires a decision on the income level necessary to achieve equality of opportunity. These implementational choices do not have standardized answers on which every expert would agree, and the choice of an answer will affect the child support values that the model produces.

236. For an explanation of household equivalence scales, see supra notes 135-140 and accompanying text. A related issue each model must address is the point at which parental income ceases to enhance the child's standard of living. Most current guidelines apply only to income below a statutorily defined dollar value; for incoine above that level, a discretionary approach is utilized. See Burt S. Bamow, Economic Studies of Expenditures on Children and Their Relationship to Child Support Guidelines, in NeXT GenERATION, supra note 16, at 18, 26. The assumption on which this approach is based, perhaps valid, is that at high incoune levels additional income is unlikely to produce direct benefits to the child. But we lack information on expenditure patterns in high income families and thus cannot verify the assumption. See $i d$. at 26. For contrasting examples of current approaches to the high-income obligor, compare McGinley v. Herman, 57 Cal. Rptr. 2d 921 (Cal. App. 1996), with Marriage of Bush, 547 N.E.2d 590 (IIl. App. 1989).

237. The method by which the U.S. poverty line is now calculated has been criticized on a variety of counts. See, e.g., Nat. Res. Council, Panel on Poverty and Family assistance, Measuring Poverty: A New Aprroach (Constance F. Citro \& Robert T. Michael eds., 1995) (describing and critieizing methodology by which U.S. poverty thresholds are calculated); Maggie Spade, Poverty Measures Mask the Depth of Poverty in America, Clearninghouse Rev., Aug.Sept. 1994, at 517 (same). Some demographers argue that poverty is more accurately measured as a percentage of median income. See, e.g., Hernandez, supra note 1, at 238-41. 
Table 1 shows the results of the four models, at varying income levels, for a one-child family in which the mother will assume sole custody; it also shows the effect upon the initial award of remarriage and a change in the mother's and father's income. The underlying implementational choices upon which these results are dependent-all subject to debate-are noted facing the table.

TABLE 1

UNADJUSTED RESULTS OF FOUR CHILD SUPPORT MODELS

FOR A ONE-CHILD FAMILY (\$ PER MONTH CHILD SUPPORT \& \% OF OBLIGOR INCOME) BY PARENTAL INCOME

\begin{tabular}{|c|c|c|c|c|}
\hline TOTALNET MONTHLY & MODELA & MODEL B & MODEL C & MODEL D \\
\hline INCOME: FATHER'S (F) \& & WELFARE & POVERTY & LIMIIED & FULL \\
\hline MOTHER'S (M) NET INCOME & PREVENTION* & PREVENTION** & EQUALTYY*** & EQUALITY+ \\
\hline STATUS CHANGES & \$MO / INC.\% & $\$ \mathrm{MO} / \mathbb{I N C} . \%$ & \$MO / INC.\% & $\$ M O / \mathbb{N} C . \%$ \\
\hline \multicolumn{5}{|l|}{ Case 1: $\$ 600$} \\
\hline$F \$ 600 ; M \$ 0$ & $\$ 300 / 50 \%$ & $\$ 600 / 100 \%$ & $\$ 336 / 56 \%$ & $\$ 336 / 56 \%$ \\
\hline F's income up $20 \%(\$ 720)$ & $\$ 300 / 42 \%$ & $\$ 720 / 100 \%$ & $\$ 403 / 56 \%$ & $\$ 403 / 56 \%$ \\
\hline$M$ 's income rises to $\$ 500$ & $\$ 144 / 24 \%$ & $\$ 311 / 52 \%$ & $\$ 116 / 19 \%$ & $\$ 116 / 19 \%$ \\
\hline F remarries (no new income) & $\$ 300 / 50 \%$ & $\$ 600 / 100 \%$ & $\$ 300 / 50 \%$ & $\$ 300 / 50 \%$ \\
\hline M remarries ( $\$ 600$ new income) & $\$ 144 / 24 \%$ & $\$ 360 / 60 \%$ & $\$ 120 / 20 \%$ & $\$ 120 / 20 \%$ \\
\hline \multicolumn{5}{|l|}{ Case 2: $\$ 1500$} \\
\hline$F \$ 1000 ; M \$ 500$ & $\$ 240 / 24 \%$ & $\$ 311 / 31 \%$ & $\$ 326 / 33 \%$ & $\$ 340 / 34 \%$ \\
\hline F's income up 20\% (\$1200) & $\$ 288 / 24 \%$ & $\$ 311 / 26 \%$ & $\$ 422 / 35 \%$ & $\$ 442 / 37 \%$ \\
\hline M's income up 20\% (\$600) & $\$ 240 / 24 \%$ & $\$ 240 / 24 \%$ & $\$ 254 / 25 \%$ & $\$ 296 / 30 \%$ \\
\hline F remarries ( $\$ 500$ new income) & $\$ 240 / 16 \%$ & $\$ 311 / 21 \%$ & $\$ 500 / 33 \%$ & $\$ 500 / 33 \%$ \\
\hline M remarries ( $\$ 1000$ new income) & $\$ 240 / 24 \%$ & $\$ 240 / 24 \%$ & $\$ 225 / 23 \%$ & $\$ 225 / 23 \%$ \\
\hline \multicolumn{5}{|l|}{ Case 3: $\$ 3000$} \\
\hline$F \$ 2000 ; M \$ 1000$ & $\$ 480 / 24 \%$ & $\$ 480 / 24 \%$ & $\$ 830 / 42 \%$ & $\$ 830 / 42 \%$ \\
\hline F's income up $20 \%(\$ 2400)$ & $\$ 576 / 24 \%$ & $\$ 576 / 24 \%$ & $\$ 1073 / 45 \%$ & $\$ 1074 / 45 \%$ \\
\hline M's income up 20\% (\$1200) & $\$ 480 / 24 \%$ & $\$ 480 / 24 \%$ & $\$ 752 / 38 \%$ & $\$ 752 / 38 \%$ \\
\hline F remarries ( $\$ 1000$ new income) & $\$ 480 / 16 \%$ & $\$ 480 / 16 \%$ & $\$ 960 / 32 \%$ & $\$ 960 / 32 \%$ \\
\hline M remarries ( $\$ 2000$ new income) & $\$ 480 / 24 \%$ & $\$ 480 / 24 \%$ & $\$ 225 / 8 \%$ & $\$ 450 / 15 \%$ \\
\hline \multicolumn{5}{|l|}{ Case 4: $\$ 5000$} \\
\hline$F \$ 2500 ; M \$ 2500$ & $\$ 600 / 24 \%$ & $\$ 600 / 24 \%$ & $\$ 275 / 11 \%$ & $\$ 550 / 22 \%$ \\
\hline F's income up 20\% (\$3000) & $\$ 642 / 24 \%$ & $\$ 642 / 24 \%$ & $\$ 428 / 14 \%$ & $\$ 855 / 29 \%$ \\
\hline $\mathrm{M}$ 's income up $20 \%(\$ 3000)$ & $\$ 600 / 24 \%$ & $\$ 600 / 24 \%$ & $\$ 178 / 7 \%$ & $\$ 355 / 14 \%$ \\
\hline F remarties ( $\$ 2500$ new income) & $\$ 600 / 12 \%$ & $\$ 600 / 12 \%$ & $\$ 588 / 12 \%$ & $\$ 1175 / 24 \%$ \\
\hline$M$ remarries ( $\$ 2500$ new income) & $\$ 600 / 24 \%$ & $\$ 600 / 24 \%$ & $\$ 88 / 4 \%$ & $\$ 175 / 7 \%$ \\
\hline
\end{tabular}


* MODEL A-A monthly public assistance grant is assumed to equal $\$ 300$, based on an average 1993 AFDC grant of $\$ 373$ for an average 2.9 person family. See Notebook, Welfare: Who Gets It? How Much Does It Cost?, N.Y. TImes, Mar. 23, 1995, at A23 (reporting data from 1994 Green Book). Child support values in excess of a public assistance level are derived using an income shares approach, the most common continuity-of-expenditure guideline type. For a one-child family, income shares guidelines require a child support award ranging from 18\%-24\% of net income; actual child care costs are typically added to the basic award. DODSON \& ENTMACHER, supra note 14, at 96. To avoid consideration of child care costs, child support was calculated here at $24 \%$ of net income instead of the midpoint of the percentage range.

** MODEL B-The poverty line is based on the 1993 U.S. poverty thresholds for nonfarm families with a householder under age 65 ( $\$ 627$ per month for one individual; $\$ 811$ for two; $\$ 960$ for three). Statistical ABSTRACT, supra note 60, at 481 tbl.746. Child support values in excess of the poverty level are derived using an income shares approach, the most common continuity-of-expenditure guideline. For a one-child family, income shares guidelines require a child support award ranging from 18\%-24\% of net incone; actual child care costs are typically added to the basic award. DoDson \& ENTMACHER, supra note 14, at 96 . To avoid consideration of child care costs, child support was calculated here at $24 \%$ of net income instead of the midpoint of the percentage range.

*** MODEL C-For families with incomes less than 150\% of the 1993 U.S. poverty threshold, that threshold was used as a basic needs standard. For families with higher incomes, the Bureau of Labor Standards (BLS) moderate income budgets in 1993 (\$1334 for one person, \$2072 for two, \$2915 for three) were used. See U.S. Dep'T OF LABOR, Bureau of Labor Statistics, Revised

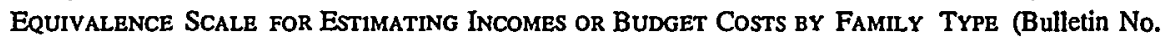
1570-2, 1968). Child support was first calculated to achieve equal income-to-needs ratios for the custodial and noncustodial households; income-to-nceds ratios were calculated using the povertylevel equivalence scale for lower-income families and the BLS equivalence scales for those with incomes above $150 \%$ of the poverty line. If this support value exceeded the child's basic needs, child support was limited to basic needs plus 50\% of "excess" support. Here are two examples: 1) Case 2 is governed by the poverty threshold basic needs standard because aggregate family income is less than $150 \%$ ( $\$ 2156)$ of the combined poverty thresholds for a one (\$627) and two-person family (\$811). The poverty-level equivalence scale requires that the custodial unit receive $56 \%$ of total family incoine to aehieve an incoine-to-needs ratio equal to that of the noncustodial parent. As $56 \%$ of total family income ( $\$ 1500$ ) equals $\$ 840$, more than the $\$ 811$ monthly poverty threshold for a twoperson family, child support is reduced to $\$ 311$ ( $\$ 811-\$ 500$ mother's income) plus (.50( $\$ 340-\$ 311)$ ), or $\$ 326$. 2) When the mother reinarries total family income rises to $\$ 2500$ per month, more than $150 \%$ of the combined poverty thresholds for families of three plus one $(\$ 2380)$. The BLS equivalence scale requires that $69 \%$ of total family income go to the custodial unit, producing a child support award of $\$ 225(.69(\$ 2500)-\$ 1500)$. As this award gives the custodial household an income $(\$ 1725)$ less than the basic needs standard $(\$ 2915)$, no adjustment is necessary.

+ MODEL D-Child support was set at a value that would produce equal incoine-to-needs ratios for the custodial and noncustodial household. The poverty-level equivalence scale was used to calculate income-to-needs ratios for families with incomes less than $150 \%$ of the 1993 poverty threshold; the BLS equivalence scale was used for higher income families. 
The results displayed in Table 1 show, first of all, just how sensitive the models are to the assumptions used to generate a payment schedule. For example, the initial awards generated by the autonomy and community models are far more disparate in Case 3 than in Case 2, even though both fathers earned two-thirds of the family's income. The reason is simply that, because the Case 2 family is low-incoine, the U.S. poverty standards were utilized to generate support awards while in higher income Case 3, the Bureau of Labor Standards (BLS) moderate income budgets were used. The BLS and poverty standards employ different underlying household equivalence scales and thus produce substantially different percentage-based outcoines. ${ }^{238}$

The table also demonstrates that each model produces payment, work, and/or marriage disincentives. A payment disincentive is most apparent in the case of poor parents under Model B; it is highly unlikely that support enforcement agencies could realistically collect $100 \%$ of a parent's wages! Even Models C and D, which require collection of more than half of the Case 1 parent's earnings, would likely face major enforcement difficulties. ${ }^{239}$ Depending on the public benefits available to a single adult, enforcement might even cost the state more unoney than could be gained. Models A and B also create serious work disincentives for very poor parents, who would be required to pay one hundred per cent of each new dollar earned until the child support

238. Household equivalence scales were generated for both the BLS and poverty threshold income standards using a two-parent, one-child family as a baseline. By comparing the budgets required for a one-person and two-person family with that baseline it is possible to determine the percentage of family income needed by the divided family to maintain the same standard of living. For exainple, using the poverty thresholds, a divided three-person family requires $\$ 627+\$ 811$ per month (\$1438), while an intact three-person family requires $\$ 960$; to maintain its living standard the divided family would require $150 \%(\$ 1438 / \$ 960)$ of its former income. The noncustodial parent requires $65.3 \%(\$ 627 / \$ 960)$ of family income to maintain his living standard; the custodial parent and child $84.5 \%$ ( $\$ 811 / \$ 960)$. Equal income-to-needs ratios can be calculated by dividing the percentage of family income each household requires to maintain its living standard by the total percentage of family income that the entire divided family would need to maintain its living standard. Thus, to achieve equal income-to-needs ratios, the custodial household would require $56 \%(84.5 \% / 150 \%)$ of total family income, the non-custodial household $44 \%$ (65\%/150\%). Using the same methodology, the BLS income standards require that $69 \%$ of family income go to the custodial household im order to achieve equal income-to-needs rations. Use of a different baseline or different budget may produce substantially different results. See, e.g., DoDson \& ENTMACHER, supra note 14, at 88-89 (describing similar methodology applied to two-parent, two-child family baseline under BLS and poverty threshold standards and reaching different results).

239. See, e.g., Beller \& GrahaM, supra note 8, at 50-51 (concluding that when fathers who are "less villing or less able to pay... [are] brought reluctantly into the system by reforms in the child support enforcement program," the result may be "a decline in the proportion of awards collected"); Judi Bartfeld \& Daniel R. Meyer, Are There Really Deadbeat Dads? The Relationship Between Ability to Pay, Enforcement, and Compliance in Nonmarital Child Support Cases, 68 Soc. SERV. REv. 219, 230 (1994) (reporting significant inverse relationship in sample of paternity cases between percentage of income awarded in child support and likelihood of compliance); Sandra $\mathrm{K}$. Danziger \& Ann Nichols-Casebolt, Child Support in Paternity Cases, 64 Soc. SERv. Rev. 458 (1990) (same). 
award exceeds a public assistance (or poverty-level) budget. Model D may also create serious work and/or marriage disincentives in cases involving new income from increased earnings or marriage, as the model sometimes requires modification of the initial support value that taxes the income gain at inore than fifty per cent.

Experts agree that high tax rates create significant negative payment and work incentives, ${ }^{240}$ but unfortunately there is no consensus on the magnitude of the effect. Using "plausible" labor supply elasticities, economist David Betson calculated the labor supply effect of switching from a continuity-of-expenditure child support formula to an equal outcomes model; with a $\$ 30,000$ family income, two-thirds produced by the noncustodial parent, the net effect was a reduction in total income of about eleven percent. ${ }^{241}$ Betson concluded that children were still better off under an equal outcomes model than a continuityof-expenditure formula, ${ }^{242}$ but did not attempt to calculate the effect of nonpayment and income concealment. Nor did he offer an optimal formula.

For purposes of refining the models enough to roughly compare their results, I have assumed that optimal preservation of work and payment incentives requires an initial support rate that does not exceed forty percent, an approximation of the current maximum income tax rate, and a modification rate that does not exceed thirty-three percent. I offer these numbers simply as a plausible estimates; they may well be too high or too low. ${ }^{243}$ Table 2 presents corrected results, relying on these assumptions, for all four models.

240. See, e.g., Michael J. Graetz, To Praise the Estate Tax, Not To Bury It, 93 YALE LJ. 259 (1983) ("High income tax rates both create marginal disincentives to productivity and stimulate legal and illegal noncompliance.").

241. Betson, supra note 21, at 17.

242. See id. at 18-19.

243. The suggsted maximum is consistent with the maximum rate advocated by a distinguished English commentator. See John Eekelaar, Third Thoughts on Child Support, 24 FAM. L. 99, 101 (1994), cited in Oldham, supra note 11, at 706, 713 (suggesting that English maintenance requirement child support percentage be reduced from $50 \%$ to $40 \%$ to reduce work disincentives). The maximum modification rate is consistent with standards that formerly governed earned income retention by AFDC recipients. As we have very little data on the relationship between child support rates and earnings, refined estimates of optimal support rates would require substantial empirical research. 
TABLE 2

ADJUSTED RESULTS OF FOUR CHILD SUPPORT MODELS FOR A ONE-CHILD FAMILY

(\$ PER MONTH \& \% OF OBLIGOR INCOME)

BY PARENTAL INCOME LEVEL

\begin{tabular}{|c|c|c|c|c|}
\hline $\begin{array}{l}\text { TOTAL NET MONTHLY } \\
\text { INCOME: FATHER'S (F) \& } \\
\text { MOTHER'S (M) NET INCOME } \\
\text { STATUS CHANGES }\end{array}$ & $\begin{array}{c}\text { MODEL A } \\
\text { (WELFARE } \\
\text { PREVENTION) } \\
\text { \$MO / INC.\% }\end{array}$ & $\begin{array}{c}\text { MODEL B } \\
\text { (POVERTY } \\
\text { PREVENTION) } \\
\text { \$MO / INC.\% }\end{array}$ & $\begin{array}{l}\text { MODEL C } \\
\text { (LIMTIED } \\
\text { EQUALITY) } \\
\text { \$MO / INC.\% }\end{array}$ & $\begin{array}{l}\text { MODEL D } \\
\text { (FULL } \\
\text { EQUALITY) } \\
\text { \$MO / INC. } \%\end{array}$ \\
\hline \multicolumn{5}{|l|}{ Case 1: $\$ 600$} \\
\hline$F \$ 600 ; M \$ 0$ & $\$ 240 / 40 \%$ & $\$ 240 / 40 \%$ & $\$ 240 / 40 \%$ & $\$ 240 / 40 \%$ \\
\hline F's income up 20\% (\$720) & $\$ 280 / 32 \%$ & $\$ 280 / 32 \%$ & $\$ 280 / 32 \%$ & $\$ 280 / 329$ \\
\hline$M$ 's income rises to $\$ 500$ & $\$ 144 / 24 \%$ & $\$ 240 / 40 \%$ & $\$ 116 / 19 \%$ & $\$ 116 / 19 \%$ \\
\hline F remarties (no new income) & $\$ 240 / 40 \%$ & $\$ 240 / 40 \%$ & $\$ 240 / 40 \%$ & $\$ 240 / 40 \%$ \\
\hline$M$ remarries ( $\$ 600$ new income) & $\$ 144 / 24 \%$ & $\$ 240 / 40 \%$ & $\$ 120 / 20 \%$ & $\$ 120 / 20 \%$ \\
\hline \multicolumn{5}{|l|}{ Case 2: $\$ 1500$} \\
\hline$F \$ 1000 ; M \$ 500$ & $\$ 240 / 24 \%$ & $\$ 311 / 31 \%$ & $\$ 326 / 33 \%$ & $\$ 340 / 34 \%$ \\
\hline F's income up 20\% (\$1200) & $\$ 288 / 24 \%$ & $\$ 311 / 26 \%$ & $\$ 392 / 33 \%$ & $\$ 406 / 34 \%$ \\
\hline M's income up 20\% $(\$ 600)$ & $\$ 240 / 24 \%$ & $\$ 278 / 28 \%$ & $\$ 293 / 29 \%$ & $\$ 307 / 31 \%$ \\
\hline F remarries ( $\$ 500$ new income) & $\$ 240 / 16 \%$ & $\$ 311 / 21 \%$ & $\$ 491 / 33 \%$ & $\$ 500 / 3390$ \\
\hline$M$ remarries ( $\$ 1000$ naw income) & $\$ 240 / 24 \%$ & $\$ 240 / 24 \%$ & $\$ 225 / 23 \%$ & $\$ 225 / 23 \%$ \\
\hline \multicolumn{5}{|l|}{ Case 3: $\$ 3000$} \\
\hline$F \$ 2000 ; M \$ 1000$ & $\$ 480 / 24 \%$ & $\$ 480 / 24 \%$ & $\$ 800 / 40 \%$ & $\$ 800 / 40 \%$ \\
\hline F's income up 20\% $(\$ 2400)$ & $\$ 576 / 24 \%$ & $\$ 576 / 24 \%$ & $\$ 932 / 39 \%$ & $\$ 932 / 39 \%$ \\
\hline M's income up $20 \%(\$ 1200)$ & $\$ 480 / 24 \%$ & $\$ 480 / 24 \%$ & $\$ 752 / 38 \%$ & $\$ 752 / 38 \%$ \\
\hline F remarries ( $\$ 1000$ new income) & $\$ 480 / 16 \%$ & $\$ 480 / 16 \%$ & $\$ 960 / 32 \%$ & $\$ 960 / 32 \%$ \\
\hline$M$ remarries ( $\$ 2000$ new income) & $\$ 480 / 24 \%$ & $\$ 480 / 24 \%$ & $\$ 140 / 7 \%$ & $\$ 450 / 23 \%$ \\
\hline \multicolumn{5}{|l|}{ Case 4: $\$ 5000$} \\
\hline$F \$ 2500 ; M \$ 2500$ & $\$ 600 / 24 \%$ & $\$ 600 / 24 \%$ & $\$ 275 / 11 \%$ & $\$ 550 / 22 \%$ \\
\hline F's income up 20\% $(\$ 3000)$ & $\$ 720 / 24 \%$ & $\$ 720 / 24 \%$ & $\$ 428 / 14 \%$ & $\$ 715 / 24 \%$ \\
\hline M's income up $20 \%(\$ 3000)$ & $\$ 600 / 24 \%$ & $\$ 600 / 24 \%$ & $\$ 178 / 7 \%$ & $\$ 385 / 15 \%$ \\
\hline F remarries ( $\$ 2500$ new income) & $\$ 600 / 12 \%$ & $\$ 600 / 24 \%$ & $\$ 588 / 12 \%$ & $\$ 1175 / 24 \%$ \\
\hline M remarries ( $\$ 2500$ new income) & $\$ 600 / 24 \%$ & $\$ 600 / 24 \%$ & $\$ 88 / 4 \%$ & $\$ 175 / 7 \%$ \\
\hline
\end{tabular}

The results displayed in Table 2 show, first of all, that none of the models uniformly advantage either the custodial or noncustodial household. Because, under all of the models, the support obligation was reduced across-the-board for poor obligors to avoid work and payment disincentives, all of the models produce consistent awards for 
low-income families. For families in which parental income is fairly equal, the autonomy models produce higher initial awards than the community models. For example, in Case 4, where each parent earns $\$ 2500$ per month, both autonomy models produce awards of $\$ 600$ per month, while Model C (Limited Equality) produces an award of $\$ 275$ and Model D (Full Equality), $\$ 550$. In the more typical case in which the noncustodial parent earns the larger share of family income, the community models produce initial awards larger than those generated by the autonomy models. Thus in Case 3, where Father earns $\$ 2000$ and Mother $\$ 1000$ per month, both community models produce awards ( $\$ 800$ per month) about $60 \%$ higher than those generated by the autonomy models ( $\$ 480$ per month). But because the autonomy models are relatively insensitive to changes in income and family composition, the typical support obligor who earns a high percentage of family income may fare better, over time, under a community model. This is particularly likely when the custodial parent remarries. ${ }^{244}$ The rate of remarriage among divorced mothers is quite high, ${ }^{245}$ and the available evidence suggests that, on average, the living standard of this group is as high after remarriage as it was before divorce. ${ }^{246}$

Table 2 also shows that the community models (C and $D)$ meet the welfare/poverty prevention aims of the autonomy models (A and $B$ ) just as well as the autonomy models do themselves. Put somewhat differently, as all of the models produce approximately the same level of welfare/poverty prevention, we do not need to decide whether welfare/poverty prevention is an important policy goal. The choice of a model will depend on whether we want the additional sharing that the community models demand.

\section{B. Contemporary Attitudes Toward Child Support}

Information on public attitudes toward child support determinations is available from only two public opinion polls, neither of which

244. Under current guidelines, researchers have reported that neither the father's nor the mother's remarriage is significantly associated with postdivorce modification of the divorce settlement. H. Elizabeth Peters et al., Enforcing Divorce Settlements: Evidence from Child Support Compliance and Award Modifications, 30 DEMOGRAPHY 719, 725 tbl.1 (1993).

245. About five-sixths of divorced men and three-quarters of divorced women remarry; about half of remarriages take place within three years of divorce. ANDrew J. Cherdin, Marriage, Divorce, Remarriage 29 (1981). See also Barbara F. Wilson \& Sally C. Clarke, Remarriages: A Demographic Profile, 13 J. FAM. Issues 123, 131 (1992). Younger women-the group most likely to be custodial mothers-remany, on average, more quickly than older women. See id. at 129 tbl.3 (reporting that the average period between divorce and remarriage was 1.5 years for women $20-24$ and 2.5 years for women $25-29$ ).

246. See, e.g., Greg J. Duncan \& Saul D. Hoffman, A Reconsideration of the Economic Consequences of Marital Dissolution, 22 DEMOGRAPHY 485, 485 (1985). 
focused on attitudes toward child support policy goals. ${ }^{247}$ The more detailed of the two surveys, described in two published reports, is the 1985 Wisconsin Survey of Children, Incomes, and Program Participation (CHIPPS). ${ }^{248}$ CHIPPS, which obtained responses from more than a thousand individuals by random-digit telephone dialing, asked each respondent whether the support obligation should vary based on remarriage, cost-of-living change, a shift in the obligor's income, and the custodial parent's income. ${ }^{249}$ Respondeuts were also presented with three child support cases and asked to come up with appropriate child support awards. Approximately three-quarters of the respondeuts indicated that the value of the support obligation should vary with a shift in either the cost-of-living or the noncustodial parent's income. About the same percentage indicated that the support obligation should also vary based on the value of the custodial parent's iucome. ${ }^{250}$ By contrast, only $36.5 \%$ reported that a noncustodial father's remarriage should affect the support award. ${ }^{251}$ Analysis of responses to the child support caseswhere respondents were given information on the number of children, marital status, and income of each parent-yielded consisteut results; the number of children, marital status, and income of each parent were all significantly related to the size of the average award, as was the gender of the respondent. ${ }^{252}$

The other child support survey was conducted in Maryland in 1992 and produced results consisteut with those reported from the CHIPPS poll. Although response patterns again varied significantly by gender, ${ }^{253}$ the Maryland respondents also favored a support award that varied with cost-of-living and income shifts. ${ }^{254}$

247. See Barbara R. Bergmann \& Sherry Wetchler, Child Support Awards: State Guidelines vs. Public Opinion, 29 FAM. L.Q. 483 (1995); Thomas Corbett et al., Public Opinion About a Child Support Assurance System, in Child Support Assurance: Design Issues, Expected Impacts, and Political Barriers as SEen from Wisconsin 339 (Irwin Garfinkel et al. eds., 1992); Nora C. Schaeffer, Principles of Justice in Judgments About Child Support, 69 SOC. FORCES 157, 163 (1990). In recent years at least thirty-eight public opinion polls have investigated attitudes toward child support. But these polls invariably focus on rating support as a public concern or gauging the level of interest in various enforcement techniques. See Public Opinion Online (visited March 1, 1996) <http://www.___.

248. See Corbett, supra note 247, at 342-54; Schaeffer, supra note 247.

249. See Corbett, supra note 247, at 343-46; Schaeffer, supra note 247, at 163-64.

250. See Corbett, supra note 247 , at 346 (reporting $74.3 \%$ of respondents favored modification of patemal support obligation based on change in the cost of living; $73.6 \%$ favored modification based on a change in the noncustodial father's income; $74.5 \%$ said that the paternal support obligation should vary depending on the custiodial mother's income).

251. See id.

252. See Schaeffer, supra note 247, at 168 tbl.2. Values for each variable were generated randomly with equal probabilities for each variable. See id. at 164.

253. See Bergman \& Wetchler, supra note 247 , at 490,492 tbl.5.

254. See id. at 490 tbl. 4,492 tbl.5. 
The CHIPPS and Maryland survey results do not unequivocally support either a community or autonomy approach. The value of awards, in both surveys, was strongly and positively linked to increases in noncustodial parent income, ${ }^{255}$ and, iu the Maryland survey, the value of awards was significantly higher than those called for under current guidelines. ${ }^{256}$ While these results support a community methodology, awards were not typically high enough to produce equal living standards. ${ }^{257}$ Conversely, most respondeuts would have awarded child support even when the custodial household had a higher income than the child support obligor. ${ }^{258}$ In each survey, average award values were regressive but, since the survey respondents were not given information on poverty status or welfare dependence, it is impossible to determine whether the tendency toward regressivity reflected an underlying poverty-prevention goal.

Of course, we should not read too much into two surveys that did no more than assess unexamined "knee-jerk" reactions to the problem of child support. Because the respondents were not asked the basis for their support awards, we can only gness at the goals and policy values the numbers reflect. Nor can we know whether the respondents' initial decisions would have held constant had they been asked to choose among distributive goals and allocation inethods. Extended reflection and debate appears to change people's miuds about what outcoines are

255. See Bergman \& Wetchler, supra note 247 , at 490 tbl.4; Schaeffer, supra note 247 , at 168 tbl.2.

256. See Bergmann \& Wetchler, supra note 247, at 489 tbl.2. See also Greenberg Lake: The Analysis Group (ANLGRP), National Telephone Survey of 900 American Women (1992) (47\% of respondents indicated that "even if it means increased taxes, increas[ing] the level of child support payments is a 'top priority' or 'very important;' $27 \%$ of respondents indicated that this goal was 'somewhat important,' 16\% 'not at all important' and 11\% 'don't know."').

257. In the Maryland survey, the average award was about a quarter of the obligor's income both when the mother's income equalled the father's, and when the father made four times as much as the mother. See Bergmann \& Wetchler, supra note 247, at 489 tbl.2.

258. See Schaffer, supra note 247 , at 170 (noting that $84 \%$ of respondents awarded child support when mother earned $\$ 1500$ per month, had remarried, and was supporting one child while the father earned $\$ 1000$ per month and had not remarried; awards were also made in $57 \%$ of the cases in which the mother earned $\$ 1500$ monthly and father only $\$ 500$ monthly). The Maryland researchers do not report the proportion of respondents who awarded child support when the custodial household had a higher incoine, but do note that "[ $t$ lhe two cases among our vignettes containing this scenario were the only ones in which respondents on average awarded lower child support amounts than the Maryland guidelines." Bergmann \& Wetchler, supra note 247, at 491.

Continuity-of-expenditure type gnidelines do not typically call for a lower award than the presumptive amount when the custodial parent earns more than the noncustodial, but empirical, research suggests that, at least when the low-income noncustodial parent is female, courts frequently order no or low child support. See 1991 CHILD SuPport REPoRT, supra note 122, at 1-2 (reporting that custodial mothers had a higher support award rate and that they received approximately onethird more than that received by custodial fathers); J. Thomas Oldham, The Appropriate Child Support Award when the Noncustodial Parent Earns Less than the Custodial Pareut, 31 Hous. L. Rev. 585, 600-04 (1994) (reviewing legal standards and empirical findings). 
just, ${ }^{259}$ and even the phrasing of the question may significantly affect the choice made. ${ }^{260}$

Nevertheless, some definite trends do emerge from the survey results. Respondents appeared to believe that the value of support should not be restricted to a minimum basic needs package; that the support obligation should be based on, and updated to take account of, the current incomes and circumstances of family members; that the support calculation should include a comparative element that takes into account the circumstances of both segments of the divided family; and, finally, that a parent should contribute soinething to his child's support, even if he is worse-off than the child. Except for the respondents' insistence on support payment by a worse-off parent, these trends are all more consistent with a community than an autonomy model. ${ }^{261}$ While they do not clearly support an equal outcoines support formula, they do strongly support an approach that treats the divided family as one family, and which adjusts the support payment to equitably balance the claims of all family members.

To supplement the published survey data on child support, I conducted a survey on attitudes toward child support in my Fall 1997 Family Law class. The survey was conducted on the first day of class, before students' views had been "contaminated" by any knowledge of family law. The questionnaire indicated that its purpose was "to elicit your personal beliefs about fairness in the determination of child support, not to test your understanding of current law or outcomes." It directed respondents, when answering the questions, to respond "as if you were making laws for a just 'model' society." In response to the question, "[p]lease choose the goal you believe inost important in formulating a child support rule," $42 \%$ of the respondents indicated that the child support amount should be set at a level that will "maintain the standard of living the child enjoyed prior to parental separation;" 58\% indicated that the support amount should "equalize the living standard of the child and his or her noncustodial parent." None of the respondents indicated that child support should be set at an amount that would

259. See, e.g., Norman Frohlich \& Joe A. Oppenhenmer, Choosing Justice: An EXPERIMENTAL APPROACH TO ETHICAL THEORY 618-20 (1992) (reporting that justice principle rankings and confidence ratings changed significantly after discussion behind "veil of ignorance").

260. See Richard J. Harris, Two Insights Occasioned by Attempts to Pin Down the Equity Formula, in Psychological Perspectives on Justice, supra note 35, at 32; Richard J. Harris \& Mark A. Joyce, What's Fair? It Depends on How You Phrase the Question, 38 J. Personality \& Soc. Psychol. 165 (1980); Roger Tourangeau et al., Belief Accessibility and Context Effects in Attitude Measurement, 25 J. EXPERMmental Psychol. 401 (1989).

261. The only exception to this tendency appears in response to the noncustodial parent's remarriage. This may refiect a belief that a parent's prior commitments take precedence over those he made subsequently. Or the survey respondents may have assumed that a new spouse would also be an income producer. 
"ensure that the child's basic needs are met," "maintain the noncustodial parent's child-related expenditure at what it would be in an intact family," or "ensure that the child does not burden the community by becoming a recipient of public assistance." While a group of law students is not a representative cross-section of the general popula$\operatorname{tion}^{262}$ and answers to specific questions about "factors that a legislature might require courts to take into account in making child support decisions" indicated some ambivalence about a "pure" equal outcomes goal, ${ }^{263}$ the respondents' complete rejection of both the continuity-ofexpenditure and autonomy-based models is nonetheless striking and provides support for a community-based approach.

\section{Evidence from Related Areas of Law}

Another way of evaluating the choice between community and autonomy is by analogy: Which approach is more consistent with other laws governing the parent-child relationship? Which is more consistent with the assumptions upon which family law generally relies?

\section{Parental Rights and Obligations: Tradition and Trends}

American law has generally followed a tradition of deference to parental decision-making. ${ }^{264}$ As a result, American parents enjoy broad discretionary powers to act against their children's interests. Parents may, for example, curtail their children's educational opportunities ${ }^{265}$ and withhold routine medical care. ${ }^{266}$ The Supreme Court has found

262. While the students were a fairly representative group in terms of gender $(50.5 \%$ were male, $49.5 \%$ female $(n=93)$ ), $82 \%$ had never been married $(n=95)$ and $91 \%$ had no children $(n=96)$.

263. Some of the answers to specific questions about "factors that a legislature might require courts to take into account in making child support decisions" were consistent with a communitybased approach $(n=96)$. $70 \%$ of respondents indicated that "the amount a parent contributes to the support of his or her children [shouldl vary depending on the income of the noncustodial parent." 75\% indicated that a parent should be required to pay child support even "when his or her income is below the poverty line." $88 \%$ thought that the support award should be adjusted when "the cost of living changes," $67 \%$ thought it should be adjusted if "the custodial parent remarries," and $61 \%$ if "the custodial parent's income changes." But other responses were inconsistent. Only $48 \%$ thought that the award should be adjusted if the noncustodial parent has other children or remarries. Only $34 \%$ thought that adjustment was in order if the noncustodial parent's income changes. The student respondents answered the "adjustment factors" questions before selecting a primary policy goal; we cannot tell how, if required to do so, they would have resolved the inconsistency in their answers.

264. See, e.g., 67A C.J.S. Parent and Child $\S 16$, at 201 (1978) (concluding that parental rights "may be limited or interfered with only for the most substantial, compelling, and sufficient reasons").

265. The Supreme Court has held that parental control over education is constitutionally protected. For descriptions and criticisin of the case law, see Suzanna Sherry, Responsible Republicanism: Educating for Citizenship, 62 U. CHI. L. REv. 131, 160-61, $171-72$ (1995); Richard J. Ameson \& lan Shapiro, Democratic Autonomy and Religious Freedom: A Critique of Wisconsin v. Yoder, in Political ORder: XXXVIII Nomos 365 (lan Shapiro \& Russell Hardin eds., 1996).

266. See, e.g., James G. Dwyer, Parents' Religion and Children's Welfare: Debunking the Doctrine of Parents' Rights, 82 CALIF. L. REv. 1371, 1382, 1396-1405 (1994) (describing and 
parental rights to be of sufficient importance to deserve constitutional protection; it has held that the state may not overrule a parent's childrearing decision unless the child's health or safety is threatened. ${ }^{267}$ This tradition of deference to parental decision making is, of course, highly compatible with the minimalist, parent-centered approach that underlies traditional support law and the autonomy-focused support models. Both focus on parental entitlement rather than the children's needs.

While the tradition of deference to parents is still strong, for at least the past two centuries it has been on the decline. Two hundred years ago, a parent could indenture his child to whom and on whatever terms he pleased; $; 68$ he could offer his child as much-or as little-education as he wished; and, given the lack of laws prohibiting child abuse, his disciplinary powers were virtually unlimited. ${ }^{269}$ By the late nineteenth century, parental authority had been circumscribed by laws dealing with child labor, education, and neglect, ${ }^{270}$ and the last three decades have witnessed a wave of new limitations on parental prerogatives. Child abuse laws have been strengthened ${ }^{271}$ and parent-child immunity, which historically protected the parent against a damages claim by the child, is now alive in only a minority of jurisdictions. ${ }^{272}$ Within the past two decades, the Supreme Court has also ruled that parents may not veto a

criticizing case law); Walter Wadlington, Medical Decision Making For and By Children: Tensions Between Parent, State, and Child, 1994 U. II,L. L. REv. 311, 312-14 (same).

267. See Wisconsin V. Yoder, 406 U.S. 205, 232 (1972) ("This primary role of the parents in the upbring of their children is now established beyond debate as an enduring American tradition."); Santosky v. Kramer, 455 U.S. 745, 768-70 (1982) (holding that state must support petition to terminate parental rights with clear and convincing evidence).

268. See MASON, supra note 44, at 31-39.

269. See Judith AREen, Cases and Materials on Family Law 1165-66 (3d ed. 1992) (noting that "[s]tate sponsored schools were the first serious intrusion into the right of parents to rear their own children" and summarizing shift to mandatory education); tenBroek, supra note 39 , at 288 , 292-94.

270. The most thorough account of these shifts, utilizing a variety of original sources, is contained in CHILDREN AND YOUTH IN AMERICA: A Documentary History (Robert H. Bremner ed., 1970). See also Robert H. MNook1N \& D. Kelly Weisbrod, Child, Family aNd State: Problems aNd Materials on Children aNd THE LAW 916-21, 926-36 (3d ed. 1995) (summarizing development of compulsory education and child labor laws).

271. See ClARK, SECOND EDITION, supra note 44, at 595-602 (noting that child abuse "has only been impressed upon public consciousness in the years since World War II" and describing development and functioning of child abuse reporting acts and registries); ALFRED KADUSHIN \& Judith A. Martin, Child Welfare Services 223-25 (4th ed. 1988) (noting that "the late 1960s and the 1970s showed an almost explosive growth of interest in the problem of the child requiring protection, with an emphasis on child abuse" and describing creation of U.S. Senate Subcommittee on Children and Youth in 1971 and enactment of federal Child Abuse Prevention and Treatment Act of 1974). See also Elizabeth S. Scott \& Robert E. Scott, Parents as Fiduciaries, 81 VA. L. Rev. 2401, 2435 (1995) (noting that "public concern about child abuse and neglect has increased in the past generation").

272. See Karam v. Allstate Ins. Co., 436 N.E.2d 1014, 1017 n.4 (Ohio St. 1982) (citing cases from 28 states which have abolished parent-child immunity in whole or in part). See also Annot., 6 A.L.R. 4th 1066, 1113-14 (1981). 
mature minor's reproductive decisions, ${ }^{273}$ and that a parent's entitlement to commit his child to a mental institution is not absolute. ${ }^{274}$ In sum, deference to parental authority has reached an historic low. ${ }^{275}$

The decline in parental authority has been accompanied by a shift in rhetoric. Recent commentators on parental rights may disagree about the scope and content of parental authority, but they are virtually unanimous in the view that parental rights derive from, and are limited by, the child's needs. ${ }^{276}$ This child-centered perspective on parents' rights has produced an altered account of parenthood as a functional status, rather than one derived from biology or legal entitlement. ${ }^{277}$ The new perspective has increasingly led courts to limit the rights of parents who have failed to accept parental responsibilities and to grant "parental" rights to nonparents. ${ }^{278}$ It has also produced a shift in litigation involving children. While the traditional, parent-focused perspective viewed the child as the subject of the proceeding, the new child-centered perspective views the child as a rights-bearing party entitled to legal representation. ${ }^{279}$

273. See Planned Parenthood v. Danforth, 428 U.S. 52, 74-75 (1976); Bellotti v. Baird, 443 U.S. 622, 643-44 (1979) (plurality opinion).

274. See Parham v. J.R., 442 U.S. 584 (1979).

275. For a detailed discussion of family law's evolution in the direction of a more explicit linkage between parental rights and responsibilities, see Scott \& Scott, supra note 271, at 2453-76.

276. See, e.g., Katherine T. Bartlett, Re-Expressing Parenthood, 98 YaLE L.J. 293, 294-95 (1988); John Bigelow et al., Parental Autonomy, 5 J. ApPLied PhIL. 183 (1988); Dwyer, supra note 266, at 1374; Scott \& Scott, supra note 271, at 2430-31; Barbara B. Woodhouse, Hatching the Egg: A Child-Centered Perspective on Parents' Rights, 14 Cardozo L. REv. 1747, 1748-49 (1993); Vallentyne \& Lipson, supra note 27. But see FrIED, supra note 162, at 152 ("the right to form one's child's values, one's child's life plan and the right to lavish attention on that child are extensions of the basic right not to be interfered with in doing these things for oneself ... the child is regarded as an extension of the self').

277. See, e.g., Janet L. Dolgin, Just A Gene: Judicial Assumptions About Parenthood, 40 UCLA L. REv. 637 (1993); John L. Hill, What Does It Mean To Be a "Parent"?: The Claims of Biology as the Basis for Parental Rights, 66 N.Y.U. L. REv. 353, 363 (1991); Lucy S. McGough \& Lawrence M. Shindell, Coming of Age: The Best Interests of the Child Standard in Parent-Third Party Custody Disputes, 27 EMORY L.J. 209, $243-43$ (1978); Nancy D. Polikoff, This Child Does Have Two Mothers: Redefining Parenthood to Meet the Needs of Children in Lesbian-Mother and Other Non-Traditional Families, 78 GEO. LJ. 459 (1990); Note, Looking For a Family Resemblance: The Limits of the Functional Approch to the Legal Definition of Family, 104 HARv. L. REv. 1640 (1991). See also Vallentyne \& Lipson, supra note 27.

278. See, e.g., Ira M. Ellman er al., Family Law: Cases, Text, Problems 600-04 (2d ed. 1991) (summarizing cases, statutes and scholarly commentary).

279. The U.S. Department of Justice has issued standards which provide that a child should have independent legal counsel "in any proceeding at which the custody, detention, or treatment of the

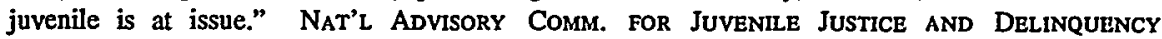
Prevention, U.S. DeP'T OF Justice, Standards for the Administration of Juvenile Justice $\S 3.132$, at 273 (1980). While most states have not gone this far in providing children with legal counsel, the provision of counsel is on the increase and most of the scholarly commentary is favorable. See, e.g., Tari Eitzen, A Child's Right to Independent Legal Representation in a Custody Dispute, 19 FAM. L.Q. 53, 61-64 (1985); Monroe Inker \& Charlotte Perretta, A Child's Right to Counsel in Custody Cases, 5 FAM. L.Q. 108, 116-19 (1971); George H. Russ, "Gregory K.": A Child's 
These various manifestations of a child-centered approach to parental rights support a community-based support model more than an autonomy-based one. But the child-centered perspective also represents only a trend, not a consistent, established tradition. ${ }^{280}$

\section{Economic Entitlements Based on Family Membership: Can Inconsistent Rules Be Justified?}

Community is clearly the emerging norm in rules governing marriage. Does logic mandate a similar approach to the parent-child relationship or can an inconsistent approach be justified?

At first glance, the differences between marriage and parenting stand out more than the similarities. The oft-cited basis for a community model of marriage is the evolution of marriage toward a "partnership of equals" norm. But parents and children are neither relational equals nor partners who have chosen each other in an armslength transaction.

While marriage involves two adults who can act as equals in a relationship of mutuality, the child's lesser age and experience ensure that parents will set the tone of the relationship. Parents will dominate family decision making, work, and income production. Parent and child may be equally important to each other, but they are not, and cannot be, relational equals.

Modern marriage relationships also derive from choice, and thus can be described as partnerships or contracts; the relationships of parents and children cannot. No child chooses her parents, and only a small number of adoptive parents choose their child. While marriage partners can freely decide whether and when to marry, many parents have children by accident rather than by design. Both parents can, by joint surrender of the child to an adoption agency, refuse to enter a parental relationship, but one parent acting alone cannot. ${ }^{281}$ Even a clear case of deception is insufficient to avoid parental obligation. ${ }^{282}$ Nor can

Right to Be Heard, 27 FAM. L.Q. 365, 378-80 (1993). See also Randy Frances Kandel, Just Ask the Kid! Toward a Rule of Children's Choice in Custody Determinations, 49 U. M1AMI L. REv. 299 (1994) (arguing that determination of custodial parent should be based exclusively on child's choice if child is more than six years of age).

280. See Martha Minow, What Ever Happened to Children's Rights?, 80 MinN. L. Rev. 267, 295 (1995) (detailing varied reasons for repeated failure of initiatives on behalf of children); Scott \& Scott, supra note 271 , at 2473 (noting "uneasy coexistence of legal outcomes that largely fit within a fiduciary framework together with legal rhetoric that continues to emphasize parental rights without responsibility").

281. Some states make an exception in the case of a nonmarital child whose mother consents to his adoption shortly after the birth.

282. See, e.g., John J. Sampson, Reconsidering the Basic Premises of Child Support: A Comment on in re Pamela P., in The Parental Child-Support Obligation, supra note 84, at 69 (describing cases and limits of contract approach to child support). 
a child legally terminate a parental tie. ${ }^{283}$ Thus the partnership or contract metaphor that we apply to marriage-and to which the community conception of marriage is so often linked-does not appear to apply to parenting. ${ }^{284}$

While inequality and lack of choice factually distinguish the parent-child relationship from that of a married couple, these differences do not necessarily justify departure from the community ideal now applicable to marriage. The roots of parent-child inequality lie in the child's dependence, which is itself the source of both the parental support obligation and the parental altruism norm. ${ }^{285}$ Parentchild inequality could thus justify a legal regime requiring more sharing behavior toward a child than toward a marital partuer, but not one that requires less. Moreover, while the community conception of marriage is typically linked with the idea of contract or partnership, it is in no way dependent on the existence of such an agreement. The marriage contract is a status contract, with terms that are largely determined by legislatures rather than by the individual marriage partners themselves. ${ }^{286}$ These terms have varied enormously over the centuries and across societies; more modest variation is evident even from one state to the

283. See Kingsley v. Kingsley, 623 So.2d 780 (Fla. Dist. Ct. App, 1993). For an argument that they should be able to do so, see Russ, supra note 279 , at 392 .

284. See, e.g., GLENDON, supra note 145 , at 131 (noting that rules that require sharing of property by marital partners "[s]ometimes ... are thought of an as an expression of the presumed intent of husbands and wives to pool their fortunes on an equal basis, share and share alike"); DUKEMINIER \& JOHANSON, supra note 72, at 484 (reporting that, under marital-sharing theory, "economic rights of each spouse are seen as deriving from an unspoken marital bargain under which the partners agree that each is to enjoy a half interest in the fruits of the marriage"); ROBERT $E$ Goodin, Protecting the Vulnerable: A Reanalysis of our Social Responsibilities 72 (1985) (noting that "[t]he received view of marriage is insistently contractual"). The application of contract principles to marriage reflects a broader legal trend:

Contract has become the dominant doctrinal current in moderu American law. In fields ranging from corporations and partnership, to landlord and tenant, to servitudes, to the law of marriage, scholars have come to understand our legal rules as resting mainly on imputed bargains that are susceptible to alteration by actual bargains.

John H. Langbein, The Contractarian Basis of the Law of Trusts, 105 YALE L.J. 625, 630 (1995).

285. This is the traditional as well as modem view. Compare LOCKE, supra note 160, at I.vi.56; II.vi.63, and 1 BLACKSTONE, supra note 42, at 447-53, with sources cited in supra note 162.

286. See Restatement (SECOND) OF CONTRACTS $\$ 190$ (1981) ("Although marriage is sometimes loosely referred to as a 'contract,' the marital relationship has not been regarded by common law as contractual in the usual sense. Many terms of the relationship are seen as largely fixed by the state and beyond the power of the parties to modify." A promise by a person contemplating marriage or by a married person is "unenforceable if it changes an essential incident of marriage such as "the duty imposed by law on one spouse to support the other ...."). See also HeGEL's PHILOSOPHY OF RIGHT \& 163 (T.M. Knox ed. \& trans., 1967) (1821) (arguing that the point of marriage is to "transcend the standpoint of contract" in favor of an attitude of "love, trust and the common sharing of their entire existence"). 
next. ${ }^{287}$ The community conception of marriage thus ultimately derives from social values, not from spousal equality or choice. ${ }^{288}$

In Anglo-American jurisprudence, the community conception of marriage is new and still grounded more in aspiration than reality. Researchers report that, despite current egalitarian ideology, the typical American husband continues to have more power within marriage than his wife. ${ }^{289}$ Husbands are more likely to dominate spending decisions; ${ }^{290}$ they are less likely, even when the wife works full-time outside the home, to perform house work or child care. ${ }^{291}$

A comparison of marriage and parenting thus should focus neither on the extent of equality and choice present in each relationship nor on how these relationships are actually lived. ${ }^{292}$ It must concentrate instead on the values and goals contemporary American society sets for each. Do we expect parents to share with their children to the same extent as a spouse, or to a lesser extent?

The evidence on current sharing expectations is, unfortunately, less plentiful than we would like. Public opinion surveys do show that the

287. Marital property law, where the rules vary substantially depending on whether the state follows community or common law principles, is a good example. See supra notes $72-80$ and accompanying text.

288. For similar views, see Goodin, supra note 284 , at 75 ("Why we insist upon ... particular duties being vritten into the '[marriage] contract' . . . has nothing to do with the values of contract or self-assumed obligations. Our insistence is grounded instead in ... what lawyers loosely dub "public policy."'); Regan, supra note 221, at 435-41 (arguing that marital duties are based on "role morality" rather than contract). See also June Carbone \& Margaret Brinig, Rethinking Marriage: Feminist Ideology, Economic Change, and Divorce Reform, 65 Tul. L. REv. 953, 1002-03 (1991) (critiquing partnership model of marriage and noting that it "embraces the existing justifications for expanded property divisions and spousal support while eschewing any effort to achieve precise calculations").

289. See, e.g., Philip Blumstein \& Pepper Schwartz, American Couples 53-59 (1983) (reporting that surveyed husbands were more likely to dominate their marriage than were surveyed wives and attributing this tendency to income inequality and "adherence to the male-provider philosophy"). See also JAN PAHL, MONEY AND MARRIAGE 169 (1989) (reporting that English husbands' greater earning power "continues to be associated with greater control over finances and greater power in decision making").

290. See Blumstein \& Schwartz, supra note 289, at 62-64; PAHL, supra note 289, at 169; Carole B. Burgoyne \& Alan Lewis, Distributive Justice in Marriage: Equality or Equity?, $4 \mathrm{~J}$. COMmunity \& APPLiEd Soc. Psycrol. 101, 101 (1994) (reporting results of research showing that "inequality between spouses is still commonplace, with the husband more likely to have overall financial control and greater access to money for personal spending"). See also MAvis MAcLEAN, Surviving Divorce: WOMEN's Resources AFTER SEParation 21-22 (1991) (summarizing several research reports).

291. See BLUMSTE1N \& Schwartz, supra note 289, at 144-46 (reporting survey data and concluding that "working wives still bear almost all the responsibility for housework"); ARLIE HochSchild, The SeCOND SH1FT 216-22, 259-62 (1989) (reporting that only $18 \%$ of surveyed husbands were as actively involved in the home as their wives and that men earning less than their wives were the least likely to participate in housework). But see Frances K. GoLdscheIDER \& LiNDA J. WAITE, NEW FAMILES, No FAmILIEs? 187 (1991) (reporting that household task sharing by both husbands and children "increases significantly as the wife's earnings rise").

292. See, e.g., Good1N, supra note 284, at 92 ("the model of voluntarily self-assumed responsibilities has little place in the analysis of special familial responsibilities"). 
average American wants to leave all of his property to his spouse, with nothing to his children, ${ }^{293}$ but most commentators attribute this trend to changes in life expectancy, residence, and the timing of intergenerational wealth transmission rather than a change in popular sentiment regarding family sharing. ${ }^{294}$ Opinion surveys also show that fewer parents are now willmg to maintain a marriage for the sake of the children than were parents a generation ago, ${ }^{295}$ but it is unclear whether this shift in opmion has resulted from a greater tendency to elevate adult interests over those of children or from a different appraisal of the risks of divorce. ${ }^{296}$

Perhaps the best evidence on sharing expectations comes from research on beliefs about distributive justice. Jennifer Hochschild, who studied American attitudes toward distributive justice in a wide range of institutions, has reported that within the nuclear family "strict equality and need predominate" as norms to which individuals profess allegiance. ${ }^{297}$ While parents often "leaven [their] focus on equality with discipline," they also believe that "[all family] members deserve equal amounts of the good being divided" and should "sacrifice equal amounts of satisfaction when necessary." 299

293. See, e.g., Mary L. Fellows et al., Public Attitudes About Property Distribution at Death and Intestate Succession Laws in the United States, 1978 AM. B. FouND. REs. J. 319, 348-64; John R. Price, The Transmission of Wealth at Death in a Community Property Jurisdiction, 50 WASH. L. REV. 277 (1975); Comment, A Comparison of lowans' Dispositive Preferences with Selected Provisions of the Iowa and Uniform Probate Codes, 63 IowA L. REv. 1041, 1078-1100 (I978). Earlier studies are cited in these publications. A strong preference for the surviving spouse has also been reported in England. See U.K. Law Comm'n, Family Law: Distribution on InTESTACY app. C, 36-37, 40-45 (1989).

294. See, e.g., Carole Shammas et al., Inhertrance in America from Colonial Times TO THE PRESENT 158-62, 204-13 (1987); John H. Langbein, The Twentieth-Century Revolution in Family Wealth Transmission, $86 \mathrm{MiCH}$. L. Rev. 722 (1988). Intergenerational transfers continue to be an important source of wealth. See William G. Gale \& John K. Scholz, Intergenerational Transfers and the Accumulation of Wealth, 8 J. EcoN. PERSP. 145, 152 tbl.4 (I994) (estimating that intergenerational transfers, ineluding bequests, college expense payments, and other intended lifetime transfers, accounted for more than $60 \%$ of aggregate U.S. net worth in 1986); Edward N. Wolff, Changing Inequality of Wealth, 82 AM. EcoN. Rev. 552, 557 (1992) (arguing that large inter vivos gifts are a major factor in wealth inequality).

295. See Arland Thornton, Changing Attitudes Toward Family Issues in the United States, $51 \mathrm{~J}$. MARRIAGE \& FAM. 873, $880 \mathrm{tbl.3}$ (1989) (reporting that approximately half of a sample of young mothers said that couples should stay together even if they could not get along in 1962, while less than $20 \%$ did so in 1985).

296. Older studies of the impact of divorce on children also tend to yield larger differences between children from divorced and nondivorced families than more recent ones. One explanation for this trend is simply that divorce has become more common. See, e.g., Paul R. Amato \& Bruce Keith, Parental Divorce and the Well-Being of Children: A Meta-Analysis, 110 Psychol. BuLl. 26 (1991).

297. Jennifer L Hochschild, What's Fair? American Beliefs About Distributive JUSTICE 107 (1981).

298. Id.

299. Id. at 52 . 
There is also evidence that the typical parent-child relationship has become more egalitarian. ${ }^{300}$ Popular sentiment no longer favors corporal punishment of children, and childhood deference to parents, along with other authority figures, has declined. ${ }^{301}$ One commentator has gone so far as to suggest the "decline of childhood and a corresponding diminution in the character of adulthood." ${ }^{" 302}$ This assessment is based on recent evidence from popular culture: films and television programming in which children behave like small adults and adults like small children, the merging of juvenile and adult styles, tastes, and recreational pursuits, and the mcrease in adult activities (sexual, criminal, substance abusive) by children..$^{303}$ But as early as the 1950 s, sociologists had begun to note the rise of an adolescent social order "in which kids look to other kids as much as to their parents for habits, values, and aspirations." ${ }^{1304}$ Evidence also suggests that "[contemporary] parents believe that they must listen carefully and at all times to their children, even that they can learn from their children-ideas which would have seemed quite preposterous just a few generations ago." 305

Like the trend toward a child-centered approach to parents' rights, these various manifestations of less hierarchical relationships between parents and children support a community support model more than they do an autonomy-based approach. The autonomy model relies on a "Father Knows Best" conception of the family in which parental rights go hand-in-hand with the assumption that parents will know, and act on, their children's best interests. By contrast, the community

300. The trend toward egalitarianism between parent and child may be longstanding and may have been accelerated by the rise in single parenting. See, e.g., RandolPh Trumbach, The Rise of THE EgaltTARIAN FAMLY (1978); Robert S. Weiss, Growing Up a Little Faster: The Experience of Growing $U_{p}$ in a Single-Parent Household, 35 J. Soc. IssUES 97 (1979) (reporting tendency by custodial mothers to treat older daughters as confidantes). There is also evidence suggesting that the trend affects a parent and child's relationship, but not responsibilities; researchers report that today's children are much less likely to share in household chores than were children in earlier generations. GOLDSCHE1DER \& WATTE, supra note 291, at 167-71.

301. See, e.g., Clare Collins, Spanking Is Becoming the New Don't, N.Y. TIMEs, May 11, 1995, at C8 (reporting survey research showing lower spanking rate among younger parents and decline in overall support for spanking from $94 \%$ approval rate in 1968 to $68 \%$ in 1994); Celia W. Dugger, $A$ Cultural Reluctance to Spare the Rod, N.Y. TIMEs, Feb. 29, 1996, at B1 (reporting anecdotal evidence of less approval and use of corporal punishment by native-born Americans than by immigrants).

302. Neil Postman, The Disappearance of Childhood 134 (1982).

303. See id. at 98-142.

304. Frankin E Zimring, The Changing Legal World of Adolescence 44 (1982). See also James S. Coleman, The Adolescent Society: The Social Life of the TeEnager and its Impact on Education (1961); John R. Seeley et al., Crestwood Heights: A Study of the Culture of Suburban Life (1956).

305. DEMOs, supra note 57, at 24, 37. See also Duane F. Alwin, From Obedience to Autonomy: Changes in Traits Desired in Children, 1924-1978, 52 PuB. OpINION Q. 33 (1988) (reporting trend toward parental preference for children's independence instead of obedience). 
model-like the egalitarian family-assumes neither parental wisdom nor altruism; parents are expected to share, no more and no less.

\section{Applying the Community Principle to Child Support: Problems and Prospects}

So far, we have seen that the community support models meet public policy goals better than does the autonomy approach. The community models satisfy the poverty prevention aims of the autonomy approach as well as the autonomy approach itself. They do a much better job of increasing support awards, the policy goal that motivated the guidelines movement in the first place. Based on the sparse evidence available, the community models more closely match public opinion trends. Finally, they appear to comport with evolving family law and cultural norms better than does the autonomy approach. These various advantages all argue strongly in favor of a community-based support policy.

\section{Community vs. Clean Break}

A community approach would apply to the parent-child relationship differently than it does to the husband-wife relationship, a difference that may negatively affect its political acceptability. With marriage partners, the community approach demands equal sharing only at the time the relationship terminates; although an aggrieved spouse may seek the imposition of a constructive trust to prevent the dissipation of marital assets, division takes place at divorce or death. While case law is sparse, courts have been extreinely loathe to interfere with actual spending patterns in an intact marriage. ${ }^{306}$ The rhetoric of community emphasizes the commitments made during marriage, but the application of a community approach focuses on the severance of those commitments. The result is that the community approach, applied to marriage, is entirely consistent with the current view of divorce as a "clean" relational break. ${ }^{307}$

By contrast, the child support obligation arises when parent and child live physically apart in an intact legal relationship; a

305. See, e.g., Clark, SEcond Edition, supra note 44, at 256-57. For criticism of such reluctance, see, for example, Joan M. Krauskopf \& Rhonda C. Thomas, Partnership Marriage: The Solution to an Ineffective and Inequitable Law of Support, 35 OHIO ST. L.J. 558, 565-67 (1974); Monrad G. Paulsen. Support Rights and Duties Between Husband and Wife, 9 VAND. L. REv. 709, 719 (1956).

307. See, e.g., LeSLIE J. HARRIS ET AL., FAMILy LAw 318-19 (1996) (describing association between no-fault divorce and the view that "judicial decrees should end, as far as possible, all personal and economic ties between the spouses" as well as implications of this view regarding postdivorce support obligations); Scott, supra note 205, at 704 ("A 'clean break' policy pervades the post[no fault] reform legal regime."). 
"winding-up," like that which occurs at divorce or spousal death, is inappropriate. In this context, the community principle would apply to income, not property; sharing would take place over time, not all at once; the emphasis would be on relational contimuity, not severance. The result is conflict with the current ideal of divorce as a clean relational break; the community models of child support assume that both parents will remain part of one family. ${ }^{308}$

This aspect of the community models, which runs counter to a deep current in contemporary culture, will almost certainly ensure opposition to its adoption. Couples who divorce typically want a clean break and, for the growing population of never-married parents, there will seldom be an ongoing familial relationship to continue. Indeed, legislative rejection of the equal outcomes approach during the period when guidelines were first adopted may have stemmed more from opposition to this emphasis on relational continuity than the "hidden alimony" issue identified by commentators; all child support models benefit the custodial parent, but not all treat that parent as an ongoing member of the support obligor's family.

While the tension between the community principle and clean break philosophy is an undeniable political disadvantage, it is not, in my view, a disadvantage on the merits. Although the desire for a clean break from a former spouse is understandable, the attainment of that aim requires abandonment of parental commitments. ${ }^{309}$ The parent who maintains a relationship with his child must maintain a relationship with the child's other parent. Visits and vacations must be planned; decisions about the child's education and medical care must be made. Nor can one parent always avoid the other at the school play, the Little League game, or the hospital bedside. Even when support obligations have terminated as a result of the child's maturity, parents will-or should-share graduation ceremonies, weddings, and grandchildren.

Noncustodial parents do not, of course, always mamtam their parental commitments; researchers report that as many as half of children with nonresidential fathers have not seen them during the past year. ${ }^{310}$ But this is hardly a pattern that public policy should encourage.

308. See, e.g., Milton C. Regan, Jr., Spouses and Strangers: Divorce Obligations and Property Rhetoric, 82 GEO. LJ. 2303, 2307 (1994) ("At least part of the financial difficulty that divorce produces for women and children reflects our inability to move beyond the dichotomy of spouses and strangers in thinking about the relationship between former spouses after divorce.")

309. For a similar view, see Regan, supra note 221, at 442 (arguing that "adult decisions about family life cannot be compartmentalized into those relating to marriage and those relating to parenthood; decisions about marital obligations effectively are decisions about parental obligations as well").

310. See Frank F. Fursteneerg, Jr. \& Andrew J. Cheri.in, Divided Families: What Happens to Children IVhen Parents Part 35 (1991) (reporting data from 1981 National Survey of Children showing that "close to half" of children had not visited with their fathers in past 12 
There is now a large body of research showing that children with an absent parent experience more problems as children and fewer successes as adults than their counterparts in intact families. The lower incomes of single-parent households appear to be the most important factor in producing these differences, ${ }^{311}$ but there is reason to believe that lower quality parent-child relationships, resulting from parental conflict, stress and absence, also play a role. ${ }^{312}$ There is also evidence that visiting and paying child support are complementary activities. ${ }^{313}$

As a number of commentators have emphasized, the "clean break philosophy may undermine parental commitment"314 and thus contribute to the tendency of noncustodial parents to ignore parental obligations. In part because of this possibility, a number of state legislatures have recently considered reintroducing limits on the availability of no-fault divorce. ${ }^{315}$ While experts remain skeptical that changes im divorce grounds would appreciably affect either the divorce

months). See also Judith A. Seltzer \& Susan M. Bianchi, Children's Contact with Absent Parents, $50 \mathrm{~J}$. MARRIAGE \& FAM. 663, 670 tbl.3 (1988) (revealing that among children living with their mother, $35 \%$ never see their father, and an additional $24 \%$ see him less than once a month); Frank L. Mott, When Is a Father Really Gone?: Paternal-Child Contact in Father-Absent Homes, 4 DEMOGRAPHY 499 (1990) (noting that $27 \%$ of noncustodial fathers visit their child once a year and $7 \%$ have never visited their child). But see MAccoBy \& MNOOKIN, supra note 117, at 176 tbl.8.2 (showing that, in Califomia divorce sample three years post-divorce, $63.9 \%$ of children living with mother saw father within the last month).

311. See supra notes 3-4 and sources cited therein.

312. See, e.g., McLanahan \& SANDEFur, supra note 4, at 95-115 (reviewing evidence); McLanahan, Intergenerational Consequences, supra note 3, at 305-06 (concluding that the "most important loss that comes with divorce... is economic insecurity and income deprivation" and noting that "there are good theoretical reasons for believing that [divorce] reduces the quantity and quality of parental investment, which in turn reduces the children's well-being").

313. See, e.g., Judith A. Seltzer et al., Family Ties After Divorce: The Relationship Between Visiting and Paying Child Support, 51 J. MARrIAGE \& FAM. 1013, 1027 (1989) (finding that "noncustodial parents who visit their children more frequently also pay more child support"); Sara $S$. McLanahan et al., Child Support Enforcement and Child Well-Being: Greater Security or Greater Conflict?, in Child Support AND Child Well-Being, supra note 109, at 239, 248-49. McLanahan found that clild support payment was significantly and positively linked both with less parcntal conflict and more noncustodial parent contact for adolescent children born to married parents; it was significantly and positively linked to more noncustodial parent contact for all clildren born to married parents. See id. For children born to unmarried parents, child support payment was significantly and negatively associated with less parental conflict; it was significantly and positively associated with noncustodial parent contact conflict. See id.

314. Elizabeth S. Scott, Rational Decisionmaking About Marriage and Divorce, 76 VA. L. REv. 9, 36 (1990) (arguing that the clean break model of the spousal relationship may undermine parental willingness to continue to contribute to the financial support of children post-divorce). See also Furstenberg \& Cherlin, supra note 310, at 118 ("For many men . . . marriage and parenthood are a package deal. Their ties to their children, and their fcelings of responsibility for their children, depend on their ties to their wives.... [I]f the marriage breaks up, the ... ties between fathers and children also are broken."); GLENDON, supra note 145, at 235 ("[t]he idea of making a clean break is wholly unrealistic in those cases where minor children are present").

315. See David Whitman, The Divorce Dilemma, U.S. News \& WorLd ReP., Sept. 30, 1996, at 58; Bill to End No-Fault Divorce in Florida Would Make it Harder to Break Up, N.Y. TIMEs, Dec. 29, 1996, at 19. 
rate or parental behavior, as a society interested in the success of the next generation we certainly have every reason for fostering parental commitunent rather than a clean break. Of course, the adoption of a community child support model is no more likely to reduce the divorce rate or dramatically affect parental behavior than are altered divorce grounds, but such a model might nonetheless help to foster parental commitment at the margins by recognizing the divided family as one family - the child's family. ${ }^{316}$ And it at least offers a legal regime based on our brightest hopes for parents rather than our worst fears. ${ }^{317}$

\section{Community vs. the Reality of Separation}

The fact that the child support obligation arises in the context of a disrupted relationship offering neither parent nor child the opportunities for noneconomic sharing available in an intact family raises a more fundamental issue: Is it fair to treat parent and child as an ongoing familial community when they lack the opportunities for dayto-day intimacy and sharing offered by a residential relationship, and may never have had such opportunities? ? $^{318}$ The issue is presented most starkly in the case of nonmarital childbearing, where the noncustodial parent may never have had a residential relationship with the child or even the other parent. ${ }^{319}$

In looking at this question, it is important to keep in mind that a community child support model does not uniformly disadvantage noncustodial parents as compared to an autonomy-based approach. Noncustodial parents who earn a relatively high percentage of family income will initially pay more support under a community approach, but the noncustodial parent whose former spouse remarries, ${ }^{320}$ whose own income declines, ${ }^{321}$ or who has additional children-situational

316. See CherliN, supra note 245 , at 85 (noting that after divorce "mother, father, and children all may have a different conception of who is in their immediate family" and that "one can no longer define 'the family' ... except in relation to a particular person").

317. For similar perspectives, see Bartlett, supra note 276, at 294 (arguing that family law should "reinforce parental dispositions toward generosity and other directedness," not "possessiveness and self-centeredness"); Martha Minow, Forming Underneath Everything that Grows: Toward a History of Family Law, 1985 W1S. L. Rev. 819, 894 (arguing that "belonging is essential to becommg" and that family law should avoid obstacles to affiliation).

318. Some commentators have argued that even current support laws may demand too much of an absent parent who lacks day-to-day contact with his child. See David L. Chambers, The Coming Curtailment of Compulsory Child Support, 80 MrCH. L. REv. 1614, 1632 (1982); Krause, supra note 62 , at 181 .

319. See sources cited supra note 145.

320. See sources cited supra notes 245-246.

321. One group of researchers has reported that, among all variables considered, modification of the original child support award was most likely to be associated with loss of the father's employment. H. Elizabeth Peters et al., Enforcing Divorce Settlements: Evidence from Child Support Compliance and Award Modifications, 30 DEMOGRAPHy 719, 725 tbl.1 (1993). 
shifts to which the autonomy-focused models are insensitive and that today produce cries of unfairness from noncustodial parents-will over time fare better under a commuuity model than under an autonomyfocused approach. ${ }^{322}$ The community model also places the noncustodial parent on a footimg equal to that of his child and former spouse; he is not expected to shoulder a significant child support burden when they are better off than he is.

Nor is the community model, when applied to marriage, restricted to those relationships that have in fact provided intimacy and sharing. The couple whose marriage is marked by distrust, withholding, violence, or even prolonged separation is treated as a community just as is the couple whose relationship involves genuine mutuality. It is the fact of marriage, not its quality, that has triggered the community standard.

The law has looked to the existence of, rather than the circumstauces surroundiug, the marriage both to avoid difficult fault judgments and to emphasize the centrality of marital status as the basis for application of the community principle. There are strong reasons for applying this status-oriented approach to the parent-child relationship as well. First, the parent-child relationship may well be, in our mobile and divorce-prone society, the most permanent of ties. ${ }^{323}$ For both pareut and child, the relationship is unique and, in many cases, irreplaceable. ${ }^{324}$ Parent and child will have only one opportunity to experience this relationship; for the child, there may be no other opportunity to relate to a parent-fignre of this gender. The quality of the relationship and the range of parental substitutes also lie entirely outside the child's control.

While the child's options for replacing a parent are fewer than those of a spouse who is dissatisfied with a marriage partner, the relationship is of even greater importance. A wealth of data, from diverse sources and theoretical schools, uuiformly demonstrates the centrality of the parent-child relationship as a determinant of the child's personality, resilience, and relationships with others. ${ }^{325}$ Decades of

322. See supra Tables 1 and 2, and accompanying text.

323. See Marcia Millman, Warm Hearts and Cold Cash: The Intimate Dynamics of FAMILIES AND MONEY I47-48 (1991) (noting that "[o]ne reason why children have become so important as a source of love is that, increasingly, they are the only permanent love relations people have in this society" and quoting a twice-divorced man as concluding that "[i]f you want to have a lasting relationship, have children").

324. For some parents and children, support eligibility is also temporary. One pair of demographers estimates that "almost one-third of children who were ever eligible [for child support] experience the reunion of their biological parents within four years of parental separation." Nazli Baydar \& Jeanne Brooks-Gunn, The Dynamics of Child Support and Its Consequences for Children, in Child Support ANd ChILd Well-BeIng, supra note 109, at 257, 280 (1994).

325. For representative examples of the literature, see JOHN BOWLBY, A SECURE BASE: Parent-Child Attachment and the Healthy Human Development (1988); Clinical Implications of AtTACHMENT (Jay Belsky \& Teresa Nezworski eds., 1988); MARGARET S. 
research have also established that a child's ties to his parents do not lose their importance simply as a result of separation or loss of day-today contact. ${ }^{326}$ "[T] he parent-child tie ... can be greatly distorted [but it] is not to be expunged by mere physical separation." ${ }^{327}$ Not even the availability of a parental substitute, for example a stepparent, renders the absent parent unimportant. ${ }^{328}$ The absent parent remains important to the child because that parent is a primary source of the child's identity and self-esteem, ${ }^{329}$ as well as her history and unique biological inheritance. Even children adopted at birth sometimes go to extraordinary lengths to obtam information about their origins, family history, and the reasons for their relinquishment. ${ }^{330}$

Finally, to restrict application of the community principle to cases in which the parent-child relationship closely approximates that of a harmonious intact family-one with a successful joint custody arrangement, for exainple-would reward the wrong kind of parental behavior. Although some commentators have speculated that the increased incidence of "casual" parenting may produce a more limited

Mahler er al., The Psychological BiRth of the Human Infant (1975); Screntific Foundations of Developmental Psychiartry (Michael C. Rutter ed., 1980); Glen H. Elder, Jr. et al., Problem Behavior and Family Relationships: Life Course and Intergenerational Themes, in Human Development and the life Course: Multidsciplinary Perspectives 293 (Aage B. Sorensen et al. eds., 1986); Seymour Epstein, The Self-Concept: a Review of the Proposal of an Integrated Theory of Personality, in Personality: Basic lssues and CURRENT Research 81 (Ervin Staub ed., 1980).

326. For descriptions of the research findings, see Michael C. Rutter, Maternal Deprivation Reassessed (2d ed. 1981); Peggy C. Davis, The Use and Abuse of the Power to Sever Family Bonds, I2 N.Y.U. Rev. L. \& Soc. Change 557, 563-72 (1983-84); Garrison, supra note 41, at 455-60; see also Penny Ruff Johnson et al., Family Foster Care Placement: The Child's Perspective, 24 ChILd WeLFARE 959, 963, 967 (1995) (reporting that all but 3 of 95 children aged 11-I4 who had been in foster care for between 6 months and 2 years indicated that they missed their families and that $56 \%$ reported "they miss their parents most of the time").

327. John Bowldy, Maternal Care and Mental Health 114 (1951). See also Judith Wallerstein \& Sandra Blakeslee, Second Chances: Men, Women, and Children a DECADE AFTER DivorCE 234 (1989) ("Children do not dismiss ... [a parent] just because there has been a divorce.... [That parent remains a] part of the ehild's emotional life, a factor in the child's self-esteem, self-image, aspirations, and relationships with the opposite sex.").

328. See, e.g., WALLERSTEIN \& BLAKESLEE, supra note 327, at 234, 246-50 (reporting that only one child in a sample of fifty-five children with stepfathers fully substituted the stepfather for their father; for the remainder of the children, stepparents were less powerful determinants of emotional well-being than the absent biological parent).

329. See Stanley Coopersmith, The Antecedents of Self-Esteem 81-117, 149-263 (1967) (analyzing relationship between parental attitudes and practiees and their children's selfesteem); Ner Littner, The Importance of Natural Parents to the Child in Placement, 54 CHILD WeLFARE 175, 178-81 (1975) (discussing advantages to foster children of contacts with natural parents). See also sources cited supra note 326.

330. See David M. Brodzinsky et al., Being Adofted: The Lifelong Search for Self 71-82, 101-10 (1992) (reporting that even a child adopted at birth feels a sense of loss for biological family); Marshall D. Schechter \& Doris Bertocci, The Meaning of the Search, in THE Psychology of Adoption 62 (David M. Brodzinsky \& Marshall D. Schechter eds., 1990) (reporting that adopted persons search for essential connections to their past). 
child support obligation, ${ }^{331}$ it is no accident that it has instead spurred a new wave of interest in child support. We cannot afford to disregard parental obligation; the consequences, to our children and to our society, simply looin too large.

Because of the centrality of the parent-child relationship, the child's inability to alter its quality, and the neutrality of a community approach - which does not prefer the child's interests to those of the parent but simply places them on an equal footing-a community approach is, in my view, fully justifiable. But to the extent that concerns relating to one or another difference between parenting and marriage leave the rule-making authority unprepared to adopt a community support model mandating full equality, the limited equality model, reliant on a community norm but offering greater deference to the noncustodial parent, is available. This approach, which might be justified based on the continuity of the parent-child relationship, ${ }^{332}$ still offers substantial improvements over both current guidelines and the autonomy approach in terms of child support outcomes.

For all the changes in family relationships, Americans continue to rank family obligations as the most important obligations ${ }^{333}$ and view tougher child support laws as an effective means of strengthening families and family values. ${ }^{334}$ It is no accident that family policy dominates political discourse and family relationships the daytime talk shows. Families come first. They are the world into which we are born, the relationships that transcend inclination, and the setting in which we learn commitment and responsibility. Because we prize those commitments and responsibilities, a community support model may yet garner broad public acceptance, as an accurate representation of our

331. See, e.g., Chambers, supra note 318, at 1632-33; Krause, supra note 318, at 181.

332. While about $90 \%$ of consumption expenditures in an intact family are for joint goods-the car, house, telephone and electricity that are utilized by all family members, see supra notes $133-135$ and accompanying text-parents in an intact family can choose inequality for at least some family expenditures; they may decide, for example, to leave the children with grandparents for two weeks and take a lavish-adult only-vacation.

333. See GLENDON, supra note 227, at 105 (describing results of survey commissioned by Massachusetts Mutual Life Insurance Company in which most respondents ranked "[b]eing responsible for your actions," and "[b]eing able to provide emotional support to your family," as their most important personal values while "[b]eing free of obligations so I can do whatever 1 want to do" came in last).

334. See Hart \& Teeter Research Companies National Telephone Survey of 1502 Adults for NBC News and Wall Street Journal, Question 59 (June 17,1994) (reporting that, in response to question on effectiveness of "several actions the governinent might take to try to strengthen families and family values," $49 \%$ of the respondents rated "tougher laws to help collect money from parents who do not make their child support payments" as "very effective," and an additional $19 \%$ rated thein as "fairly effective"). 
familial ideals ${ }^{335}$ and as a reflection of our mutual stake in tomorrow's generation.

\section{CONCLUSION}

A just child support law will conform to our considered judgments about fairness among family members and the scope of parental obligation. Current child support laws prefer the interests of the nonresident parent to those of the child, the custodial parent, and the public. Awards calculated under existing guidelines typically improve the living standard of the child support obligor, while ensuring that that of his child plummets. Many guidelines also fail to ensure that children are protected from poverty, even when parental imcome is adequate to meet that goal. The guidelines fail to achieve fair results under any contemporary account of distributive justice.

Those accounts of distributive justice all lead to one of two child support models. The "Community Model" bases the support obligation on family membership and mandates mcome sharing as a basic approach. The "Autonomy Model" bases the support obligation on both the societal burden produced by nonsupport and the nonsupporting parent's contractual obligations to the custodial parent. It mandates public assistance (or poverty) prevention and contract enforcement as basic goals.

The community support model appears to meet current public policy goals better than does the autonomy approach. It satisfies the poverty prevention aims of the autonomy model and does a much better job of increasing support awards, the goal that motivated the guidelines movement in the first place. Based on the sparse evidence available, the community model more closely corresponds to public opinion trends. Perhaps more importantly, it appears to comport with evolving family law and cultural norms better than does the autonoiny approach.

An autonomy-based perspective has strong rhetorical appeal, but fails to capture the complexity and contradictions of contemporary culture. Americans may favor individual property entitlements and clean relational breaks, but they also expect parents to make sufficient provision for their children that they do not burden the public; they view the family as an intimate association based on sharing, not a collection of autonomous individuals without obligations to each other. On balance, the case for a community child support principle is a strong one.

335. See HochSCHILD, supra note 297 , at 107 (reporting strict equality and need as norms within nuclear family). 
CALIFORNIA LAW REVIEW 